\title{
Technology Application Analyses at Five Department of Energy Sites
}

May 1995

HAZARDOUS WASTE REMEDIAL ACTIONS PROGRAM

Environmental Management and Enrichment Facilities

Oak Ridge, Tennessee 37831-7606

managed by

LOCKHEED MARTIN ENERGY SYSTEMS, INC.

for the

U.S. DEPARTMENT OF ENERGY

under contract DE-AC05-84OR21400 


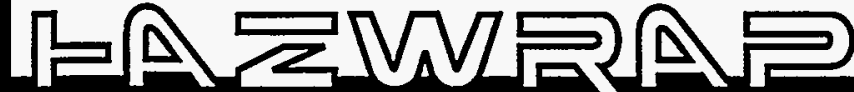

HAZARDOUS WASTE REMEDIAL AGTIONS PROGRAM

Leading the Way to Environmental Stewardship

\section{Technology Application Analyses at Five Department of Energy Sites}

May 1995

Technical Program OMicer, DOE Oak Ridge Operations Office: L. E. Velazquez HAZWRAP Division Director, Martin Marietta Energy Systems, Inc: R. L. Walker
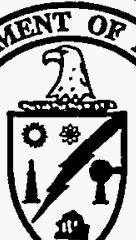

vangs

Sponsored by

U.S. Department of Energy

Oak Ridge Operations Office
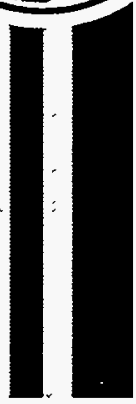

-SECEIVED

HAZARDOUS WASTE REMEDIAL ACTIONS PROGRAM

Environmental Management and Enrichment Facilities

Oak Ridge, Tennessee 37831-7606

managed by LOCKFEED MARTIN ENERGY SYSTEMS, INC.

for the DEPARTMENT OF ENERGY

under contract DE-AC05-840R21400

AU6 164995

() S TI 


\section{DISCLAIMER}

This report was prepared as an account of work sponsored by an agency of the United States Government. Neither the United States Government nor any agency thereof, nor any of their employees, makes any warranty, express or implied, or assumes any legal liability or responsibility for the accuracy, completeness, or usefulness of any information, apparatus, product, or process disclosed, or represents that its use would not infringe privately owned rights. Reference herein to any specific commercial product, process, or service by trade name, trademark, manufacturer, or otherwise, does not necessarily constitute or imply its endorsement, recommendation, or favoring by the United States Government or any agency thereof. The views and opinions of authors expressed herein do not necessarily state or reflect those of the United States Government or any agency thereof. 


\section{DISCLAIMER}

Portions of this document may be illegible in electronic image products. Images are produced from the best available original document. 


\section{CONTENTS}

EXECUTIVE SUMMARY

PUMP AND TREAT OF CONTAMINATED GROUNDWATER AT U.S. DEPARTMENT OF ENERGY SAVANNAH RIVER SITE, AIKEN, SOUTH CAROLINA

IN SITU AIR STRIPPING OF CONTAMINATED GROUNDWATER AT U.S.

DEPARTMENT OF ENERGY SAVANNAH RIVER SITE, AIKEN, SOUTH CAROLINA

PUMP AND TREAT OF CONTAMINATED GROUNDWATER AT U.S. DEPARTMENT OF ENERGY KANSAS CITY PLANT, KANSAS CITY, MISSOURI

EXTRACTION AND TREATMENT OF CONTAMINATED GROUNDWATER AT U.S. DEPARTMENT OF ENERGY LAWRENCE LIVERMORE NATIONAL LABORATORY, LIVERMORE SITE, LIVERMORE, CALIFORNIA

DYNAMIC UNDERGROUND STRIPPING OF CONTAMINATED SOIL AND GROUNDWATER AT U.S. DEPARTMENT OF ENERGY LAWRENCE LIVERMORE NATIONAL LABORATORY, LLNL GASOLINE SPILL SITE, LIVERMORE, CALIFORNIA 


\section{EXECUTIVE SUMMARY}

The Hazardous Waste Remedial Actions Program (HAZWRAP), a division of Lockheed Martin Energy Systems, Inc., managing contractor for the Department of Energy (DOE) facilities in Oak Ridge, Tennessee, was tasked by the United States Air Force (USAF) through an Interagency Agreement between DOE and the USAF, to provide five Technology Application Analysis Reports to the USAF. These reports were to provide information about DOE sites that have volatile organic compounds contaminating soil or ground water and how the sites have been remediated. The sites were using either a pump-and-treat technology or an alternative to pump-and-treat.

The USAF was looking at the DOE sites for lessons learned that could be applied to Department of Defense (DoD) problems in an effort to communicate throughout the government system. The five reports were part of a larger project undertaken by the USAF to look at over 30 sites. Many of the sites were DoD sites, but some were in the private sector.

The five DOE projects selected to be reviewed came from three sites: the Savannah River Site (SRS), the Kansas City Site, and Lawrence Livermore National Laboratory (LLNL). SRS and LLNL provided two projects each. Both provided a standard pump-and-treat application as well as an innovative technology that is an alternative to pump-and-treat.

The five reports on these sites have previously been published separately. This volume combines them to give the reader an overview of the whole project. 


\section{TECHNOLOGY APPLICATION ANALYSIS}
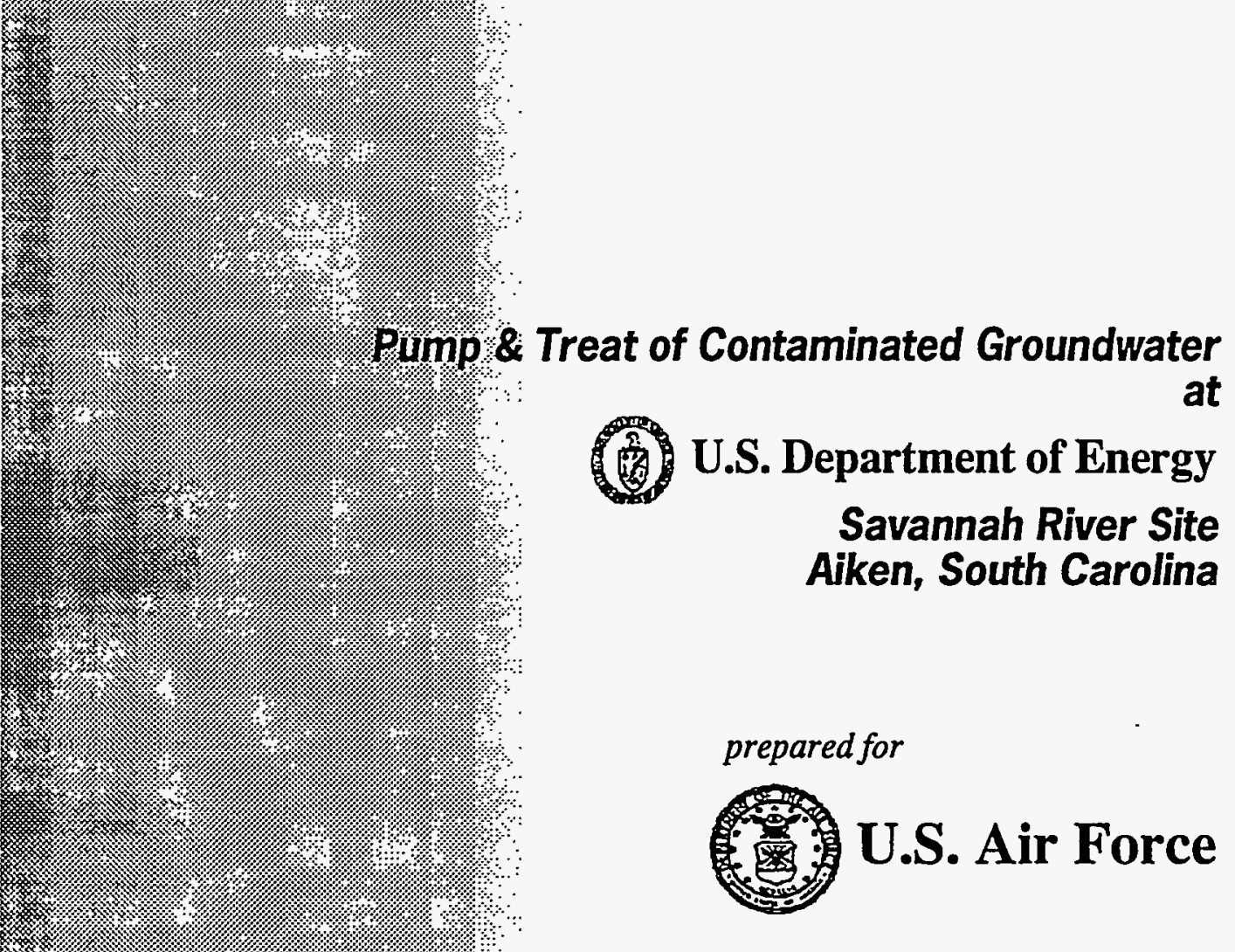

May 1994 FINAL 


\section{SITE}

U.S. Department of Energy Savannah River Slte AM Area

Aiken, South Carolina
TECHNOLOGY APPLICATION

Page 1 of $12=$

This analysis covers an effort to pump and treat groundwater contaminated with volatile organic compounds (VOCs) by above ground air stripping. Full scale treatment began in September 1985 and is one component of an ongoing environmental restoration program. This analysis covers performance through December 1993.

\section{SITE CHARACTERISTICS}

\section{Site History/Release Characteristics}

- The Savannah River Site's historical mission has been to support national defense efforts through the production of nuclear materials. Production and associated research activities have resulted in the generation of hazardous waste byproducts now managed as 266 waste management units located throughout the 300 square mile facility.

- The $A$ and $M$ areas at Savannah River have been the site of administrative buildings and manufacturing operations respectively. The Savannah River Laboratory is also located within the $A$ area. Specific manufacturing operations within the $M$ area include aluminum forming and metal finishing.

- The $M$ area operations resulted in the release of process wastewater containing an estimated 3.5 million pounds of solvents. From 1958 to 1985, 2.1 million pounds was sent to an unlined settling basin which is the main feature of the M-Area Hazardous Waste Management Facility (HWMF). The remaining 1.3 million pounds was discharged to Tims Branch, a nearby stream, during the years 1954 to 1982.

- Discovery of contamination beneath the settling basin in 1981 initiated a site assessment effort eventually involving approximately 250 monitoring wells over a broad area. A pilot groundwater remediation system began operation in February 1983. Full-scale groundwater treatment began in September 1985.

\section{Contaminants of Concern}

Contaminants of greatest concern in the groundwater are:

1,1,2-trichloroethylene (TCE)

tetrachloroethylene (PCE)

1,1,1-trichloroethane (TCA)

\section{Contaminant Properties}

Properties of contaminants focused upon during remediation are:

\begin{tabular}{|c|c|c|c|c|}
\hline Property at STP* & Units & TCE & PCE & TCA \\
\hline $\begin{array}{l}\text { Empirical Formula } \\
\text { Density }\end{array}$ & $g / \mathrm{cm}^{3}$ & $\begin{array}{l}\mathrm{CCH}=\mathrm{CO}_{2} \\
1.46\end{array}$ & $\begin{array}{l}\mathrm{C}_{2} \mathrm{C}_{-} \mathrm{CCH}_{2} \\
1.62\end{array}$ & $\begin{array}{l}\mathrm{CH}_{3} \mathrm{CO}_{3} \\
1.31\end{array}$ \\
\hline Vapor Pressure & $\mathrm{mmHg}$ & 73 & 19 & 124 \\
\hline & $m^{3} m^{3} / m d a$ & $9.9 E-3$ & $2.9 E-3$ & $1.6 \mathrm{E}-2$ \\
\hline Water Solubility & $\mathrm{mg} / \mathrm{L}$ & $1000-1470$ & $150-485$ & $300-1334$ \\
\hline $\begin{array}{l}\text { Octanol-Water } \\
\text { Cartition } \\
\text { Coefticient: Kow }\end{array}$ & - & 195 & 126 & 148 \\
\hline
\end{tabular}

\section{Nature \& Extent of Contamination}

- Approximately $71 \%$ of the total mass of VOCs released to both the settling basin and Tims Branch was PCE, $28 \%$ was TCE and $1 \%$ was TCA.

- The dissolved organic solvents are estimated to be 75\% TCE. A continued source for dissolved phaseVOCs is contaminants sorbed to solids in the saturated zone or in the vadose zone.

- The area of VOC contaminated groundwater has an approximate thickness of 150 feet, covers about 1200 acres and contains contaminant concentrations as high as $223 \mathrm{ppm}$.

- Dense nonaqueous phase liquids (DNAPLs) were found in 1991 and present complications to long term remediation efforts. 
Data from hundreds of soil borings, groundwater monitoring wells and a variety of other investigative techniques has allowed the development of a three dimensional conceptual model of the site including groundwater behavior and contaminant

concentration profiles for various geologic units. The following diagrams have been included here to provide a general understanding of site conditions. Data from the third quarter of 1985 is presented.

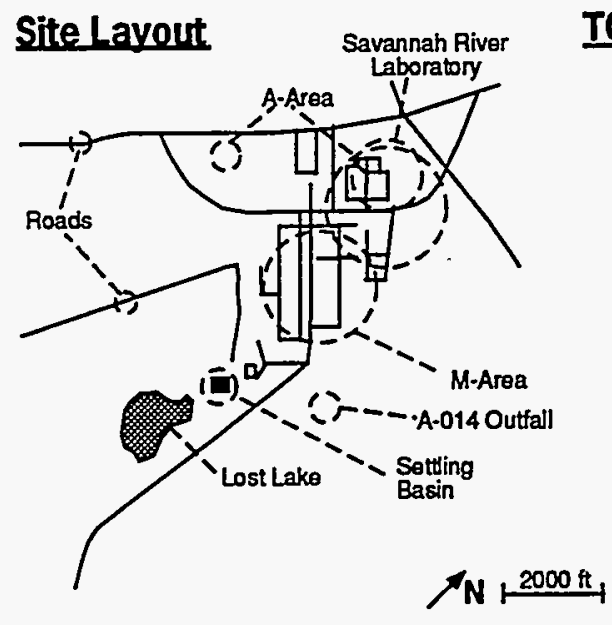

TCE Plume (Upper Lost Lake Aquifer Top View)

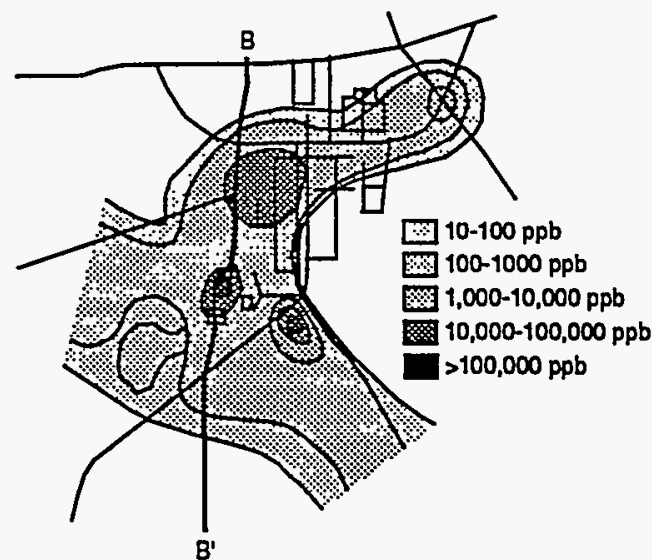

\section{ICE Plume (Side View)}

Groundwater monitoring data from the third quarter of 1985 along cross-section B-B' shown in top view

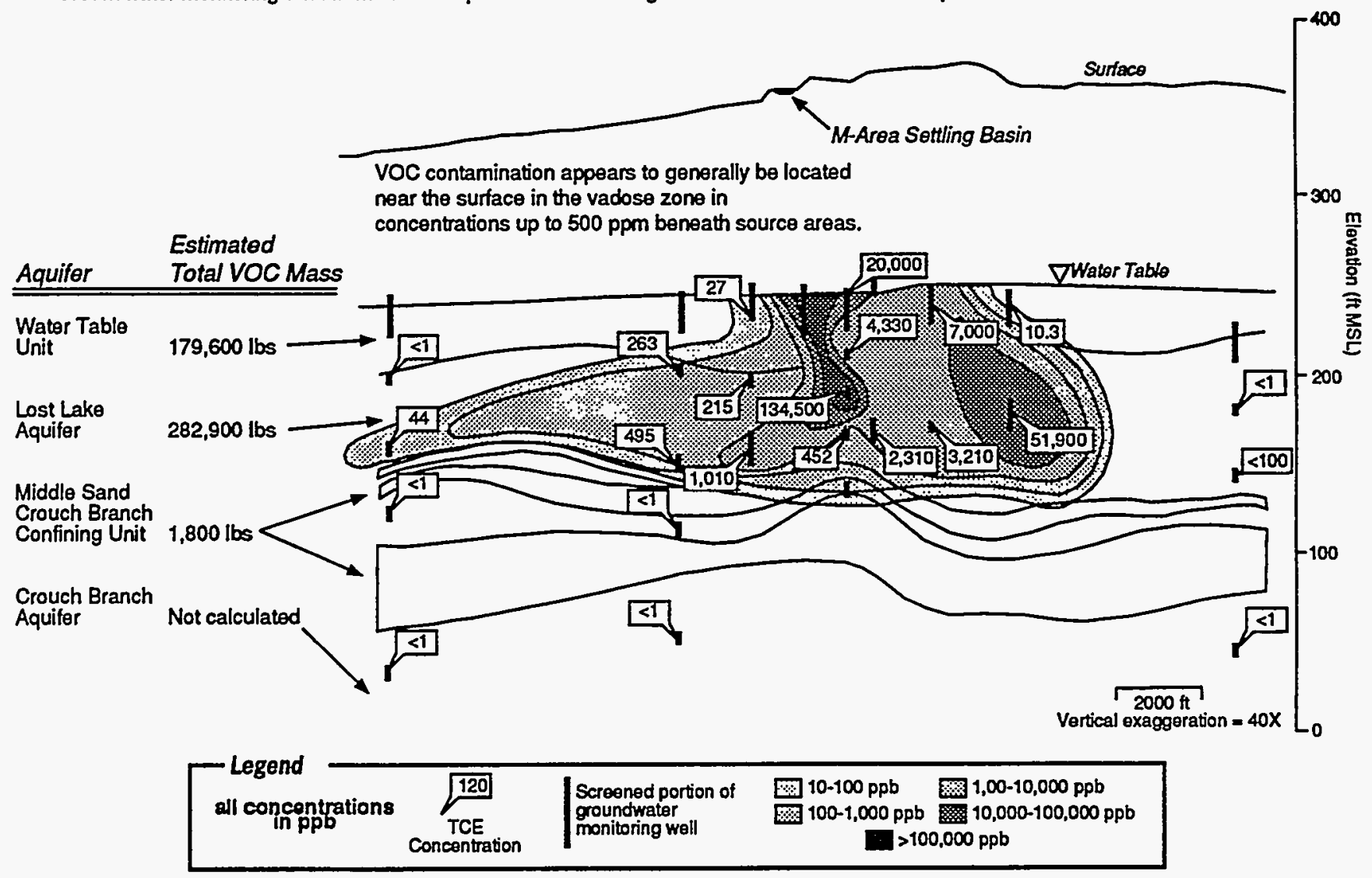




\section{Hydrogeologic Units}

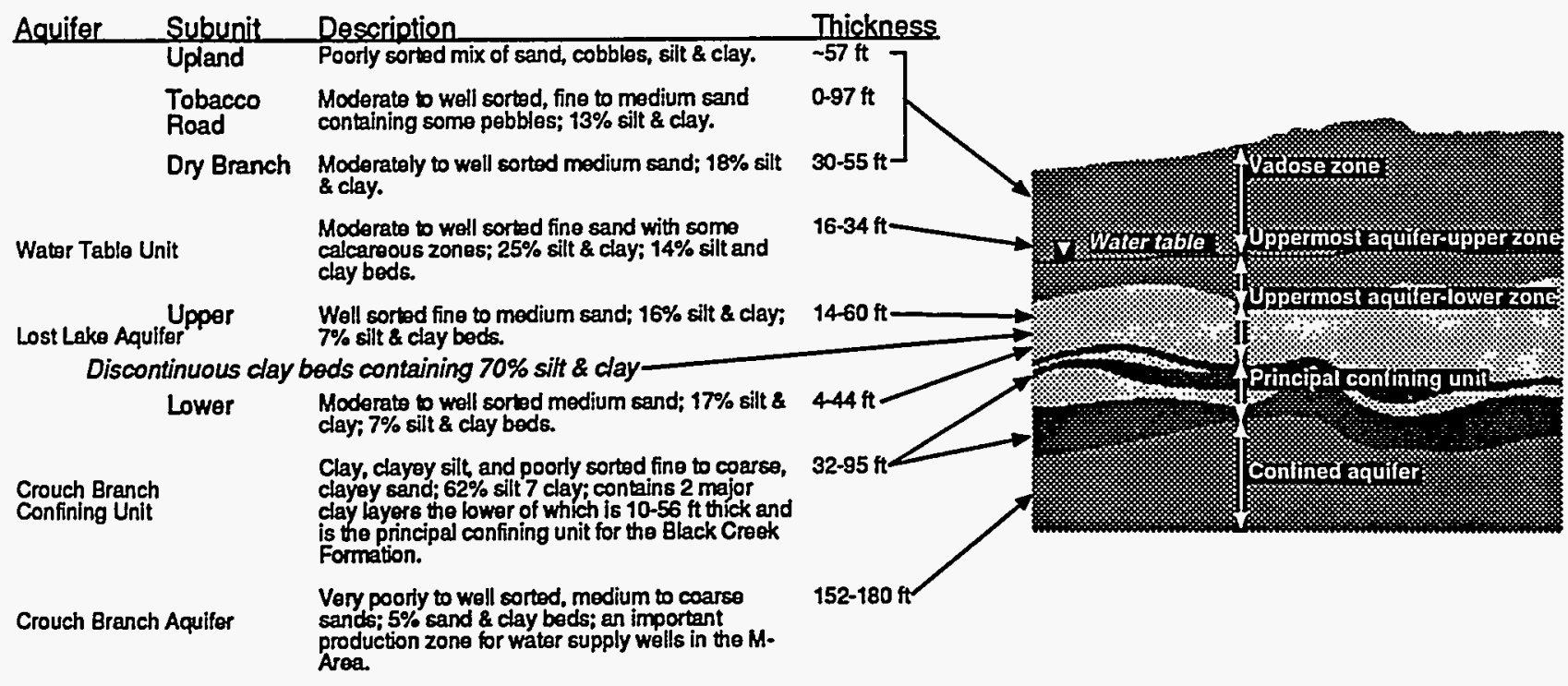

\section{Site Conditions}

- The AM-Area is approximately one mile inward from the northeast boundary of the 300 square mile Savannah River Site. Adjacent to the site boundary are rural and farming communities.

- The Savannah River Site includes a complex hydrogeology arising from heterogeneities in the multilayer aquifer system and discontinuous sand \& clay layers.

\section{Key Aquifer Characteristics}

Aquifer parameters beneath the AM-Area have been estimated as:

\begin{tabular}{|c|c|c|c|}
\hline & $\begin{array}{l}\text { Hydraulic } \\
\text { Conductivity }\end{array}$ & Transmissivity & \\
\hline Unit & [ttday] & [gpd/day] & Flow Direction \\
\hline Watar Table Unit & 9 & 175 & $\begin{array}{l}\text { Fow in the unconfined water table unit within the McBean } \\
\text { Formation is complex but radial fiow is expected outward from a } \\
\text { plateau (at } 244 \mathrm{MSL} \text { ) surrounding most of the AM-Area. }\end{array}$ \\
\hline
\end{tabular}

Lost Lake

Aquifer

Ranged from southwest to northeast near the AM-Area in the

Middle Sand

Crouch Branch

Confining Unit

Crouch Branch

Aquifer

73

12,500

Mainly southeast during 1985-86.

- A wide range of values has been used to describe regional aquifer characteristics. Uncertainties stem from difficulties in aquifer testing and interpretating methods applied to the hydrogeological complexities noted above under Site Conditions.

- A moderate downward gradient appears to exist beneath the M-Area. Vertical flow rates have been estimated to be from 2 to 8 feet per year.

- Radial flow outward from a groundwater plateau surrounding most of the AM-Area within the water table unit and Upper Lost Lake aquifer is approximately 15 to $100 \mathrm{ft}$ year.

\section{U.S. Air Force}




\section{Overall Process Schematic}

Groundwater

Extraction Well Network

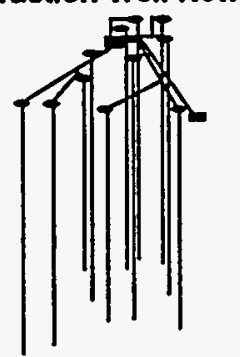

11 recovery wells each containing four $10 \mathrm{ft} \mathrm{screened} \mathrm{intervals} \mathrm{and}$ extending to depths over $200 \mathrm{ft}$ [detailed bolow]
Air Stripper

Treatment Plant

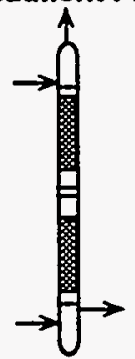

Production air stripper treating Avg. $500 \mathrm{GPM}$ [detailed on next page]
Treated

Groundwater Outfall

Treated effluent discharge to outtall A-014 feeding tributary to Tims Branch

\section{Extraction Well Network}
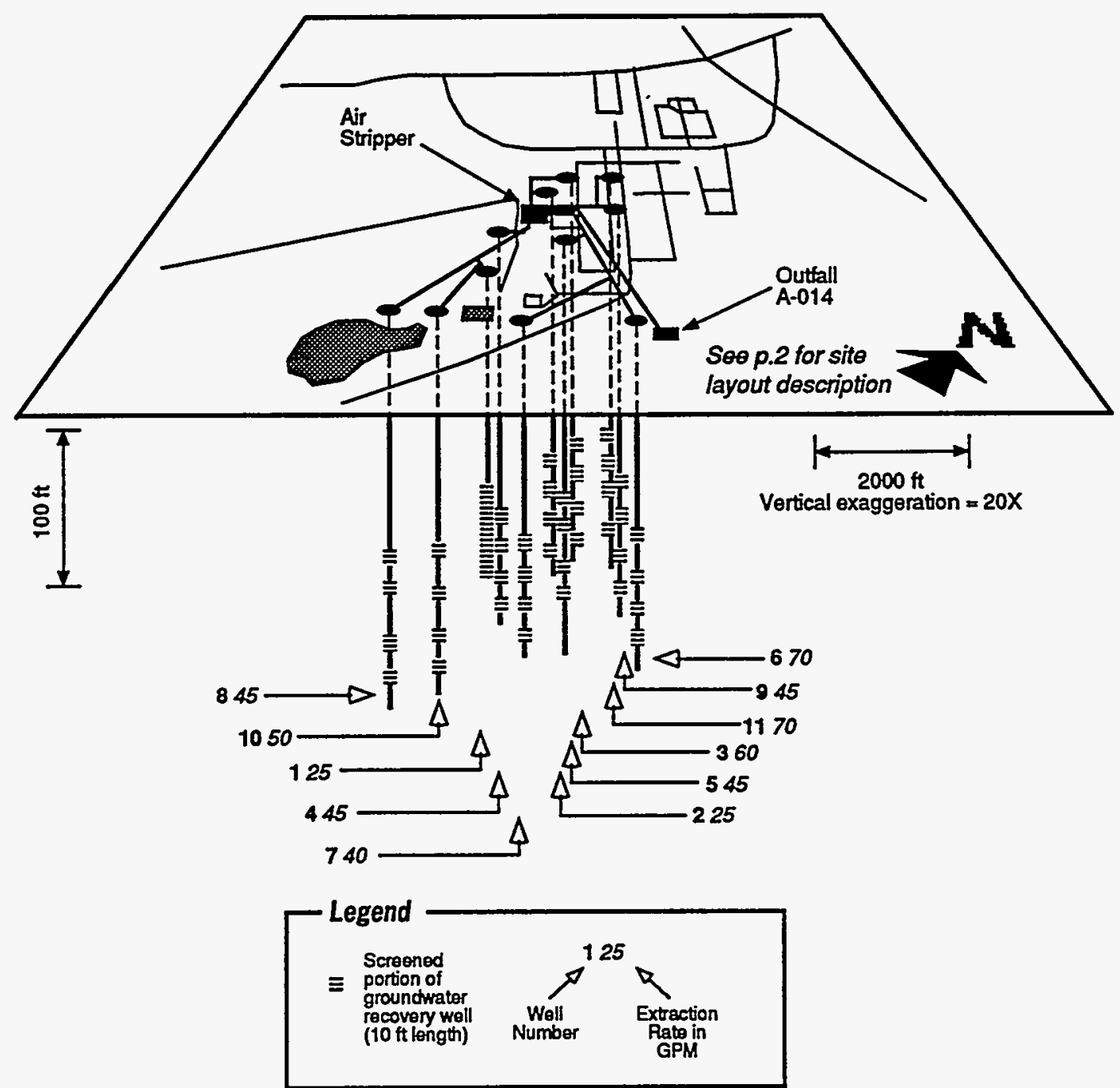


\section{Air Stripper System Schematic}

- In 1988, the original pall ring packing was replaced with cascade mini-rings to provide more surface area and less pressure drop across the system.

- In 1990, system in flow was upgraded from $\mathbf{4 0 0} \mathrm{gpm}$ to $\mathbf{5 1 0}$ gpm.

- Drawing not to scale.

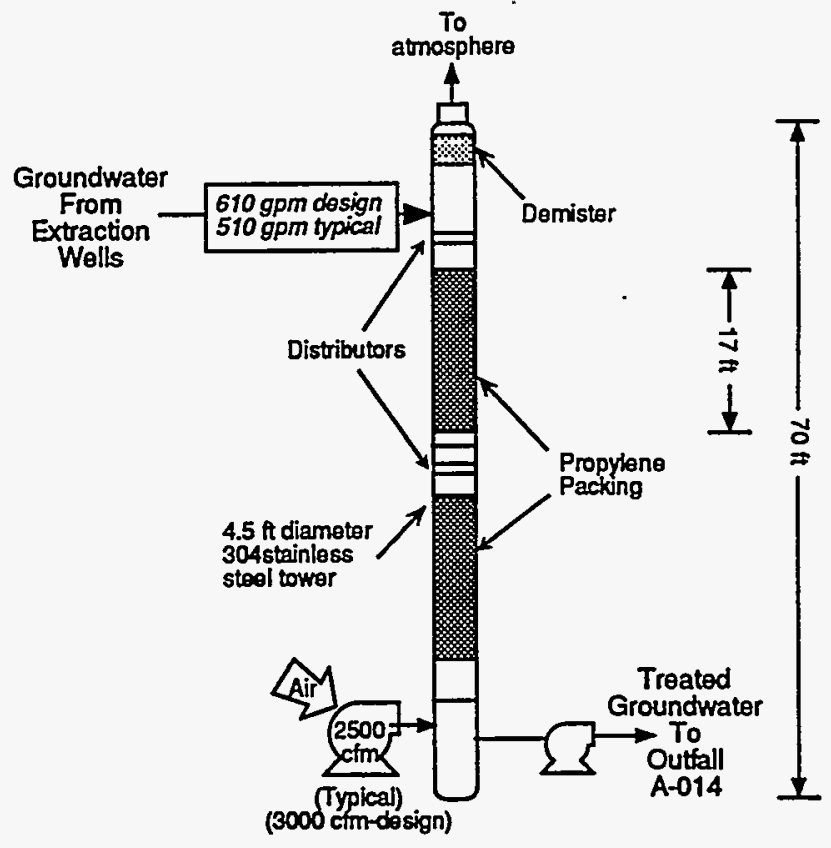

\section{Extraction Well Close-Up}

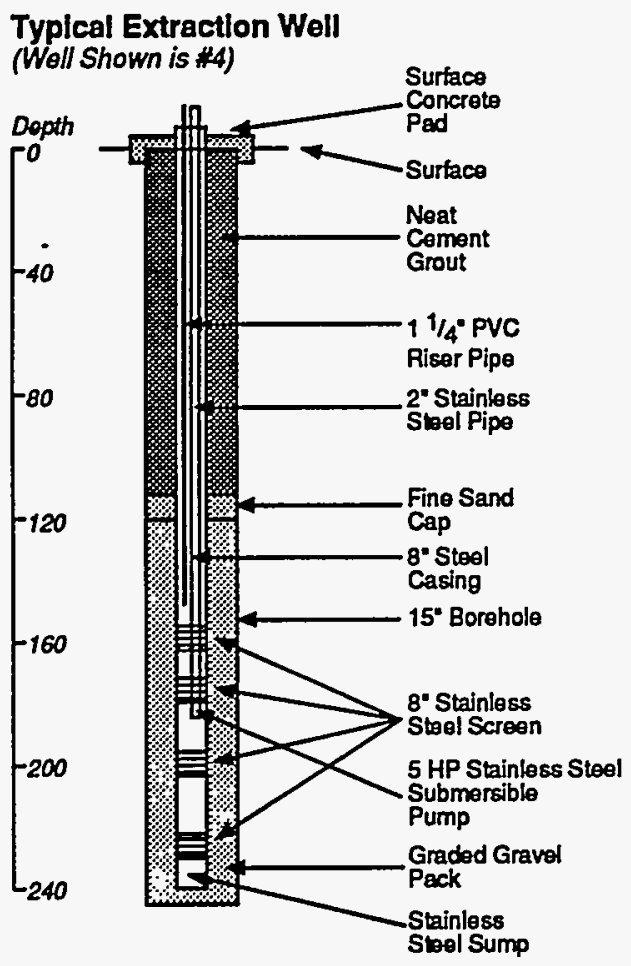

\section{Key Monitored Operating Parameters}

- Water flows

- Air flows (to assess system operation)

- Pump discharge pressures

- Groundwater lovels (to assess zone of capture)

- Contaminant concentrations in treatment plant influent \& effluent

(to assess treatment effectiveness)

- Contaminant concentrations in groundwater (to assess achievement of remediation goals) 
PERFORMANCE

- Performance Objectives

- Achievement of Groundwater Protection Standards (GWPS) established as part of a RCRA permit for the M-Area. The GWPS are based on EPA's Maximum Contaminant Levels (MCLs) of $5 \mathrm{ppb}$ for TCE and PCE and $200 \mathrm{ppb}$ for TCA.

- Prevent migration of contaminated groundwater toward the Savannah River Site boundary and downward into the confined aquifer (Black Creek Formation).

- Achieve cleanup goals within 30 years.

\section{Treatment Plan}

The overall long-term environmental restoration strategy for the AM-Areas involves an integrated approach containing three major elements. Only the larger $A M$ air stripping effort is fully detailed in this analysis:

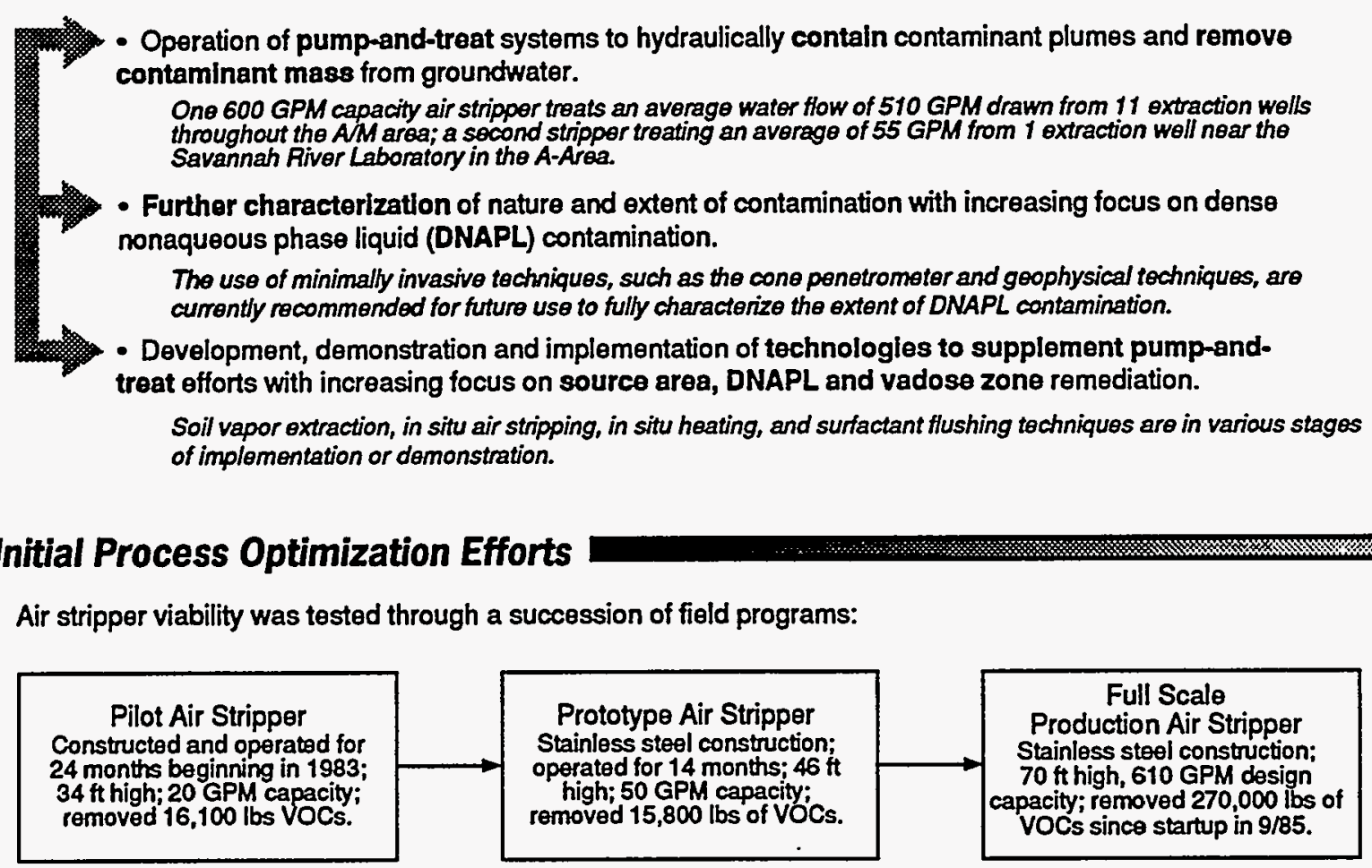

\section{- Operational Performance}

System Throughput - For 1993,243 million gallons of groundwater were
pumped from 11 recovery wells to the production air
stripper.
- Average water flow rate was $479 \mathrm{GPM}$ and average air
flow rate was $2,489 \mathrm{cfm}$ through the air stripper during
1993 .
- 19,500 lbs of vocs were removed in 1993 which
produced an average air emission rate of $2 \mathrm{lbs} / \mathrm{hr}$.

System Downtime
- Average utility for 1993 was $96.4 \%$. Cumulative average
utility since 1985 is $95.3 \%$.
- 1993 experienced 316 hours of downtime.
- Causes of downtime included scheduled maintenance,
operator training, power outages, and equipment repair.




\section{Hydrodynamic Performance}

- Current estimates of the $\mathbf{3 0}$ year zone of capture of the pump and treat system have determined that portions of the existing plume will not be effectively controlled. Contaminated groundwater beneath the Savannah River Laboratory and southeast of the settling basin are beyond the anticipated capture zone. However, contaminated groundwater in the source areas and areas of highest VOC concentration is contained.

- The downward gradient across the Crouch Branch Confining Unit, and consequently the driving force for downward contaminant migration to the confined aquifer in the Crouch Branch Aquifer, has been reduced due to pumping effects.

- The groundwater recovery wells are screened in the more permeable areas of the shallow aquifer which increase hydraulic control yet limits access to silt and clay layers where retention of contaminants may be strongest.

\section{Treatment Performance}

\section{Effects on Plume}

- Reductions in contaminant plume size and concentration as a result of remediation are evident (the $>100,000 \mathrm{ppb}$ contaminant concentration zone has disappeared) but are generally limited to areas near recovery wells.

- Significant progress is evident in the Lost Lake Aquifer where initial contaminant concentration and hydraulic conductivity are highest.

- Downward migration of VOCs to the Crouch Branch Aquifer beneath the settling basin and north of the M-Area is evident. VOC concentrations have increased slightly in the confined aquifer since 1985.

\section{TCE \& PCE vs TIme at Influent}

- The concentration of TCE in extracted groundwater has varied widely over short (one year) time frames for individual wells. Some wells have shown short term increases in contaminant concentration, some decreases and others no clear trend.

- The trends may indicate plume redistribution and may also represent a decline in plume strength.

- There has been a clear reduction in overall contaminant concentrations sent to the air stripper.

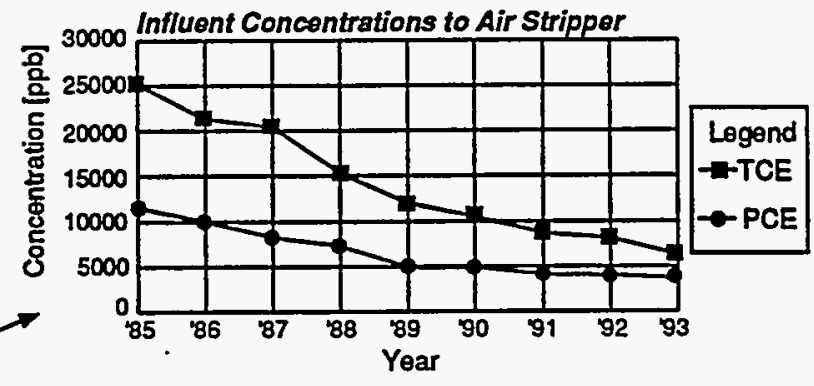

\section{Air Stripper Influent vs Effluent}

- Average VOC removal efficiency $>99.9 \%$

- All VOCs treated below discharge criteria.

$\begin{array}{lll}\text { Compound } & \begin{array}{c}\text { Average Concentration [ppb] } \\ \text { Influent }\end{array} & \begin{array}{l}\text { Effuent } \\ \text { TCE }\end{array} \\ \text { PCE } & 15,006 & <1.01 \\ \text { Total } & 6,705 & <1.0 \\ & 21,711 & <1.12\end{array}$

"data from September 1985-1993

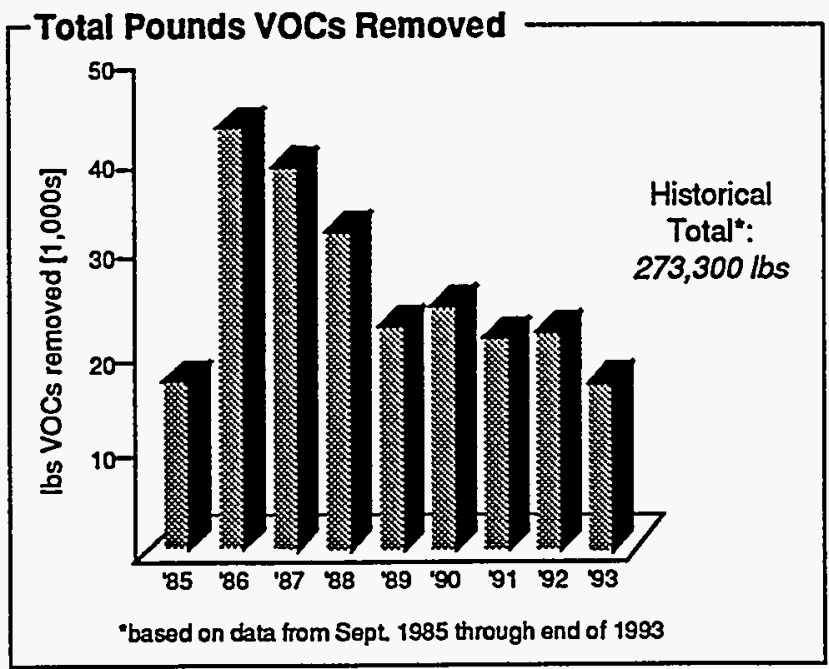


$000^{\prime} 80 L^{\prime}$ 'b\$ 18701

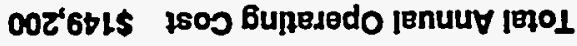

$000^{\prime} 9 \varepsilon$

$000^{\prime} \mathrm{St}$

00L'st

$000^{\prime} \varepsilon+$

OOS'E!

$000^{\circ} 92 \$$

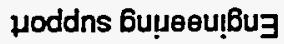

s!̣sfeue qel 8 bu!jdures $\| \theta M$ suo!joedsu! Ki!nep \& uoneledo

uoụedodo

jueweoejdel 8 d!̣eded quewd!nb

(uuse\$ D) joqe 7 өsueuejurew

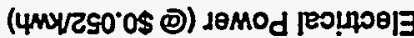

$000^{\prime} 827$

000'0हZ

$000^{\prime} z \varepsilon 1$

$000^{\prime} \mathrm{gZ6} 6$

$000^{\prime} 997$

$000^{\circ} \angle 8$

$000^{\prime}+12$

$000^{\prime} 81$

$000^{\prime} 82$

$000^{\prime} 89 \varepsilon$

$000^{\prime} 0 \mathrm{Zt} \$$

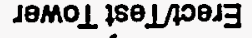

moisks jonuoo

uone|letsu LOMO 1 uoņonqsuos/bu!d!d uop̧ejuewnnsu|

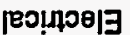

Bu!p!!ng joдuo Buนตeu!bu $\forall 0$

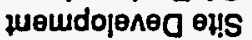

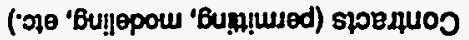
ubised

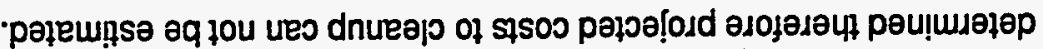

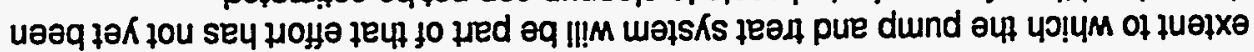

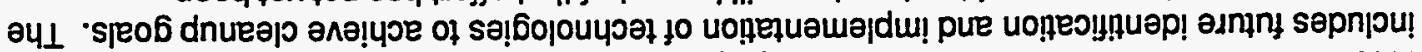

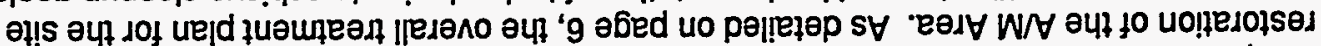

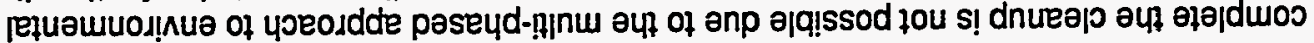

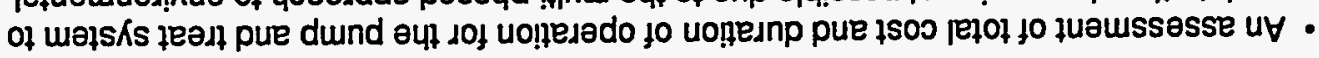

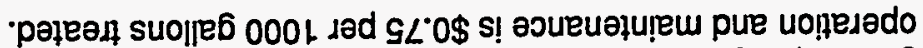

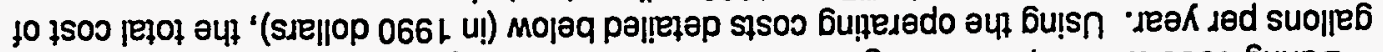

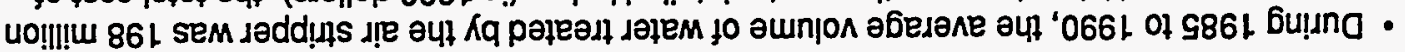

- sre |0p 066ł u! aje sqsos lie pue

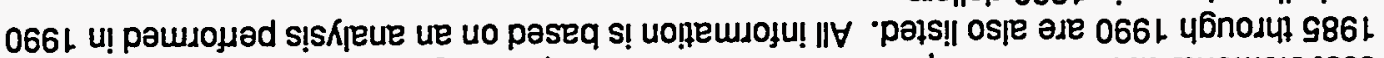

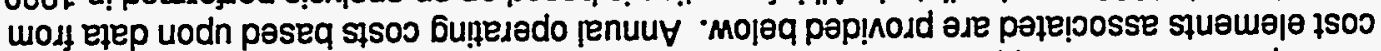

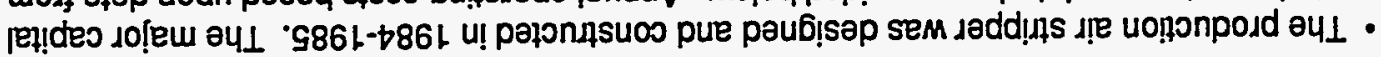


-

- The production air stripper is part of the M-Area Hazardous Waste Management Facility which is permitted
the Resource Conservation and Recovery Act (RCRA). The air stripper unit is permitted as a waste water treatment facility requiring South Carolina certified Class-D physical/chemical operators. The air stripper unit is not regulated as a RCRA treatment, storage, disposal (TSD) facility.

- The air stripper has a South Carolina Bureau of Air Quality Control permit allowing the release of 34 tons/year (or $7.9 \mathrm{lbs} / \mathrm{hr}$ ) of VOCs to the atmosphere.

- Recent Clean Air Act requirements mandate that industrial off gas systems be retrofitted with an off-gas treatment system. Catalytic oxidation has been demonstrated as an effective off-gas treatment and the M-Area air stripper is being retrofitted. The system will be installed by 1995, even though regulations for mitigation will not require retrofit until 2000.

- Treated water effluent from the stripper is released through an National Pollution Discharge Elimination System (NPDES) permitted outfall. The EPA Maximum Contaminant Levels (MCLs) listed under "Cleanup Criteria" below apply to this discharge.

- The facility's RCRA Part B permit requires periodic sampling at the recovery wells, air stripper and NPDES outfall.

- Eight production wells drawing from the Crouch Branch Confined Aquifer currently supply process and drinking water for AM-Area Site operations.

Cleanup Criterla

- During initial remediation efforts in 1985, a cleanup goal of removal of $99 \%$ of VOCs over a 30 year period was used. A CERCLA baseline risk assessment was not developed or required.

- In 1990, groundwater protection standards based upon EPA MCLs were adopted during modifications of the facility's RCRA permit. The standards are:

\begin{tabular}{cc} 
Compound & Criteria Level [ppb] \\
\cline { 1 - 2 } TCE & 5 \\
PCE & 5 \\
TCA & 200
\end{tabular}

\section{SCHEDULE}

\section{A/M-Area Remediation Mllestones}

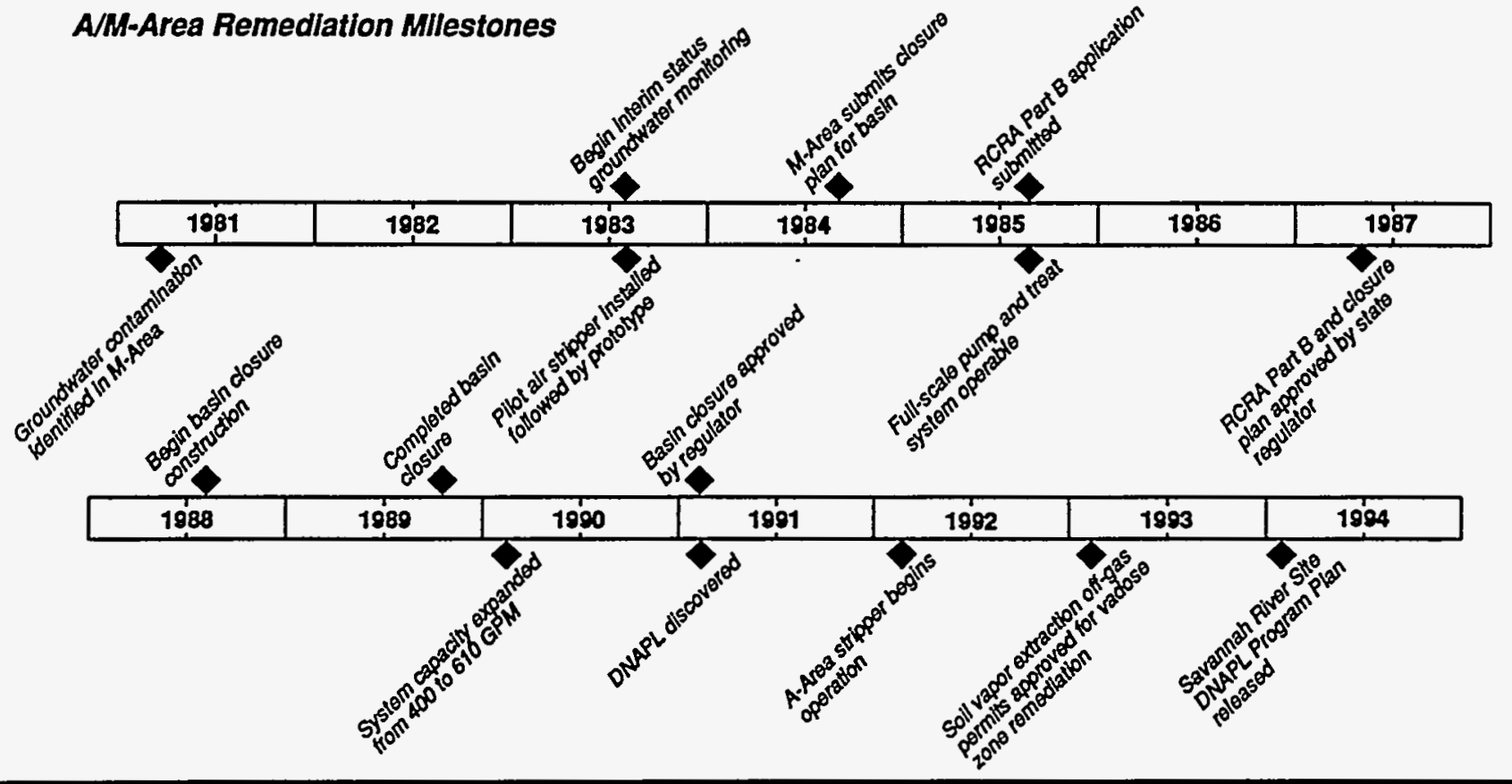




\section{Implementation Considerations}

- An integrated treatment program consisting of pump and treat for hydraulic control and dissolved plume mass removal combined with source/DNAPL targeted technologies has been determined to be the most effective long term remedial solution for the M-Area VOC plume at Savannah River.

- Technologies to supplement the pump and treat systems are in various stages of development, demonstration or implementation. These technologies focus on either the source area, DNAPL or vadose zone contamination and include soil vapor extraction, in situ air stripping, in situ bioremediation, in situ heating and surfactant flushing.

- There is a recognized need for supplemental site characterization efforts to redirect ongoing remediation activities at the site. Further characterization will focus on DNAPL contamination and will involve minimally invasive methods such as the cone penetrometer and geophysical techniques.

- Significant volumes of VOC-contaminated purge water are generated from sampling the extensive network of over 250 monitoring and compliance wells. Modifications to the air stripping system were implemented to treat this groundwater. The system changes include addition of a 10,000 gallon carbon steel receiving tank and associated piping.

\section{Technology Limitations}

- The presence of DNAPLs represents a significant long-term limitation to pump and treat due to residual DNAPL above and below the water table combined with mass removal limitations.

- Hydraulic factors, combined with the nature of contaminants, has inhibited the pump and treat system's ability to affect the fringes of the plume. However, the contaminated groundwater in the source areas and areas of highest VOC concentration is contained.

- Pump and treat is effective for plume restoration only where DNAPL source areas have been contained or removed.

\section{Future Technology Selection Considerations}

- Early M-Area remediation efforts did not address the long term prospect of removing residual levels of contamination. Future cleanups at sites with chlorinated solvents must carefully look for DNAPL during site characterization and address DNAPL and residual contamination removal as part of an overall remediation plan.

- The original aim of the pump and treat system in the M-area was for broad plume containment and destruction of $99 \%$ of the VOCs. This goal was later changed to achievement of EPA MCL based groundwater protection standards. Future pump and treat systems should consider the actual environmental and human risks, be highly designed, and address realistic elements of overall cleanup goals.

- Pump and treat for containment of dissolved contaminants is a viable tool for dissolved phase VOC removal and can be an element of presumptive remedies for such sites.

- A phased approach to site assessment and remediation is beneficial. Early actions to control plume migration and remove contaminant sources, when properly designed and implemented, can reduce risks posed by contaminated groundwater. 
This analysis was prepared by:

Stone \& Webster Environmental

Technology \& Services

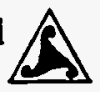

245 Summer Street

Boston, MA 02210

Contact: Bruno Brodteld (617) 589-2767

Assistance was provided by the WESTINGHOUSE SAVANNAH RIVER COMPANY which supplied key information and reviewed report drafts.

for:

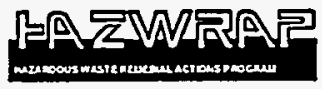

HAZARDOUS WASTE REMEDIAL ACTIONS PROGRAM Environmental Restoration and Waste Management Programs

Cak Ridge, Tennessee 37831-7606

managed by

MARTIN MARIETTA ENERGY SYSTEMS

for the

U.S. Department of Energy

under Contract DE-AC05-84OR-21400

This analysis was funded by:

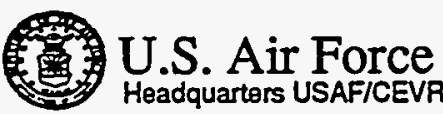

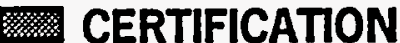

This analysis accurately reflects the performance and costs of the remediation:

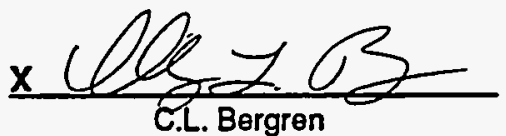

Westinghouse Savannah River Company Environmental Restoration Department Manager Northern Ground Water Facilities

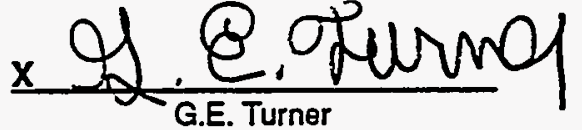

Department of Energy

Savannah River Operations Office Environmental Restoration Division Environmental Specialist 


\section{SOURCES}

Major Sources For Each Section

$\begin{array}{ll}\text { Site Characteristics: } & \text { Source \#s (from list below) 5,7,8 and } 9 \\ \text { Treatment System: } & \text { Source \#s 5,6 and } 7 \\ \text { Performance: } & \text { Source \#s 1,2,3,5 and } 7 \\ \text { Cost: } & \text { Source \# 5 } \\ \text { Regulatory/lnstitutional Issues: } & \text { Source \# } 5 \\ \text { Schodule: } & \text { Source \#s 1,5, and } 7 \\ \text { Lessons Leamed: } & \text { Source \#s 1,3, and 4. }\end{array}$

\section{Chronological List of Sources and Additional References}

1. Personal communications with J.E. Jordan, Westinghouse Savannah River Company, April 1994.

2. Corrective Action System Operation and Performanco (Draft), Fourth Quarter 1993 and 1993 Summary. WSRC-RP-93-67-4, Fobruary 1994.

3. Savannah River Site DNAPL Technical Program Plan, J.E. Jordan, etal., Westinghouse Savannah River Company, February 1994.

4. Guidance for Evaluating the Tectnical Impracticability of Ground-Water Restoration, Interim Final, U.S. EPA, September 1993.

5. MoKillip, S.T., K.L. Sibley and J.G. Horvath, Air Stripping of Volatile Organies Chlorocarbons: System Development, Performance, and Lessons Leamed, Proceedings of Waste Managment '90, Roy Post, editor, 1990.

6. Well logs for recovery wells (undated).

7. Evaluation of Ground-water Extraction Remedies: Phase /IEPA Publication 9355.4-05A, February 1992.

8. Evaluation of Ground-water Extraction Remedies, EPA540/2-89-054, September 1989.

9. Preliminary Technical Data Summary M-Area Groundwater Cleanup Facility, DuPont - Savannah River Laboratory, October 1982. 


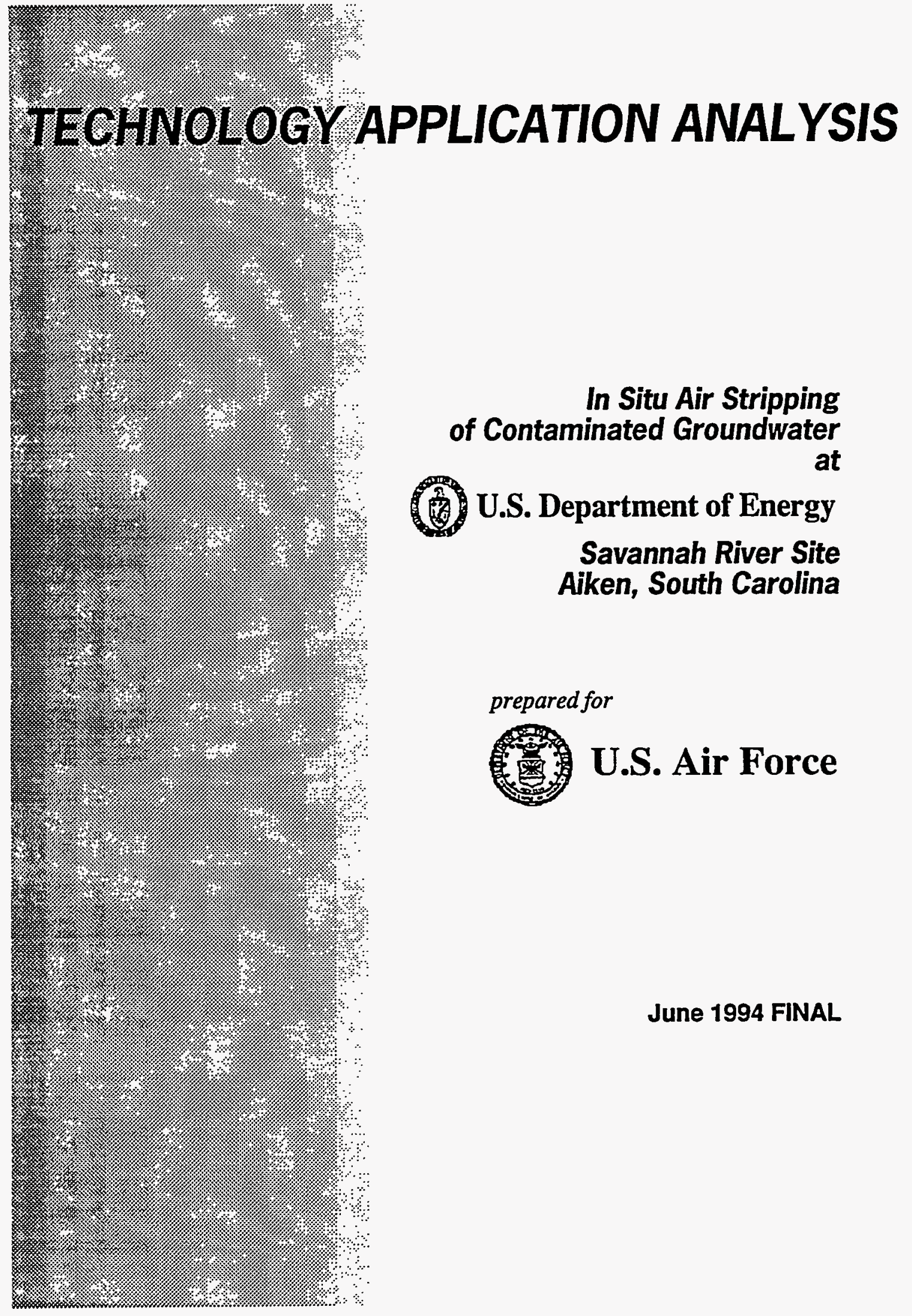




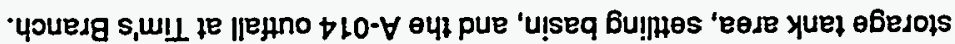

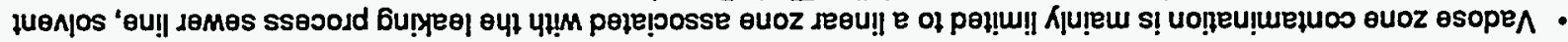

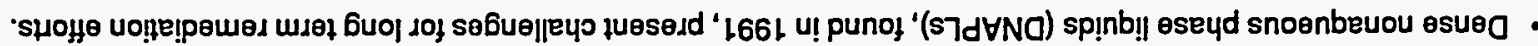

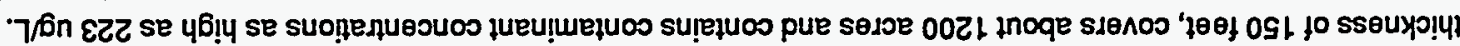

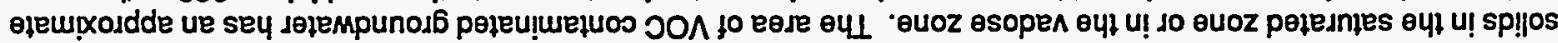

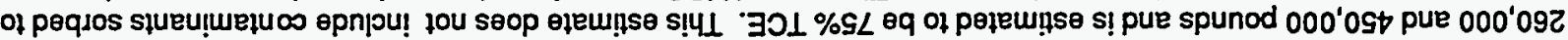

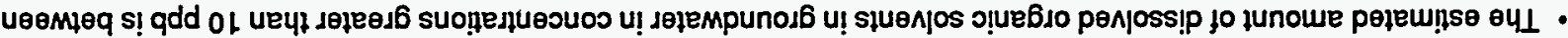

$\forall O \perp$ seM \% PUe $\exists O \perp$

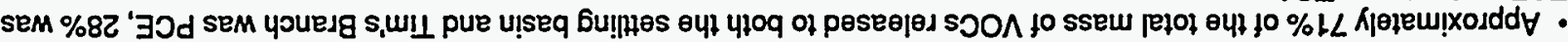

\begin{tabular}{|c|c|c|c|c|}
\hline & \multicolumn{4}{|c|}{ 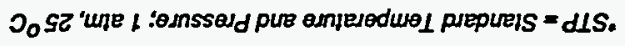 } \\
\hline 871 & 921 & $96 !$ & - & 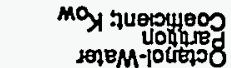 \\
\hline 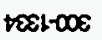 & sot-ost & $\alpha>t-\infty)$ & 76w & A!!!qnण्S renEM \\
\hline Z-ヨ9. & $\varepsilon-\exists 62$ & $\varepsilon-366$ & (ب) & 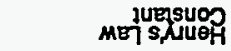 \\
\hline †Zเ & 61 & $\varepsilon\llcorner$ & BHuw & anssejd Loden \\
\hline $\begin{array}{l}\text { lE'เ } \\
\varepsilon \infty^{2}+\infty\end{array}$ & $200=\frac{29 \%}{20}$ & $\begin{array}{r}95^{\circ} 1 \\
200=1000\end{array}$ & ह & 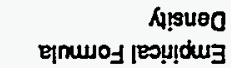 \\
\hline$\overline{\forall D \perp}$ & छगd & $\exists \supset \perp$ & ș̣un & .dIS le kuedold \\
\hline
\end{tabular}

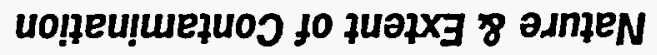

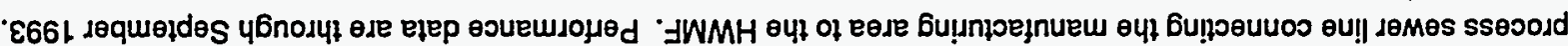

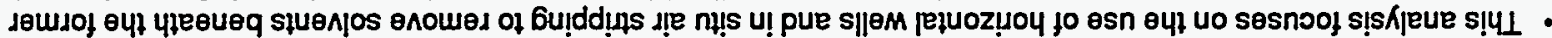

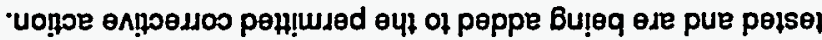

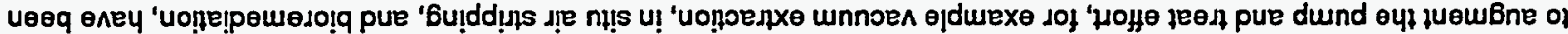

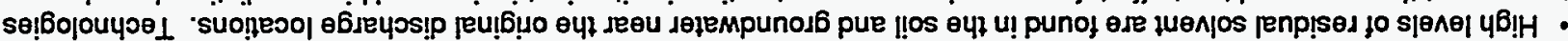

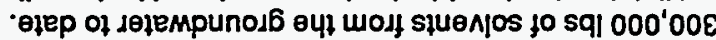

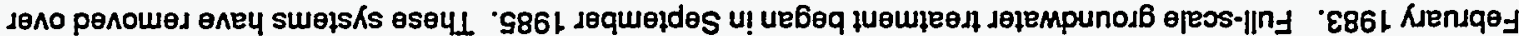

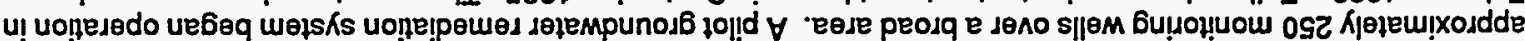

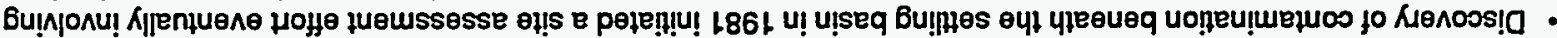

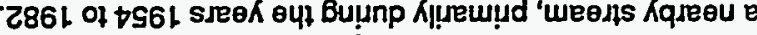

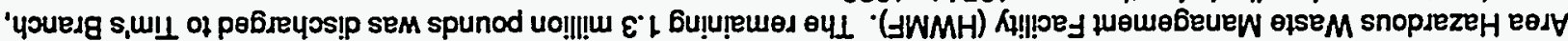

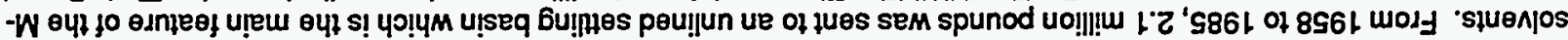

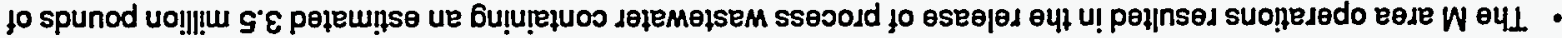

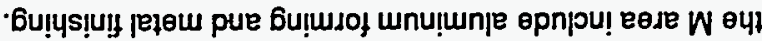

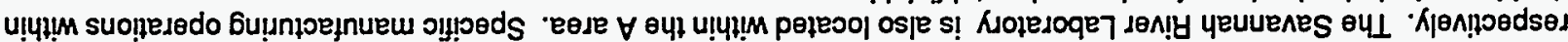

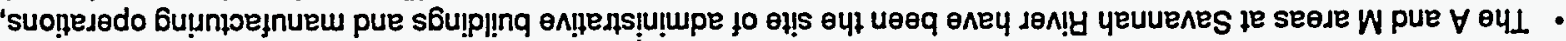

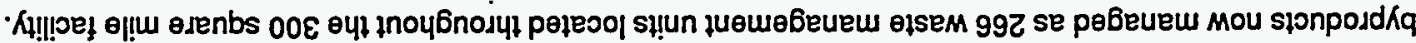

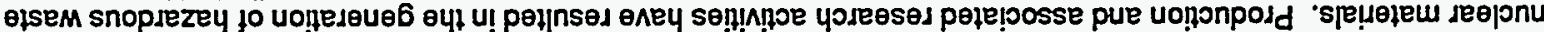

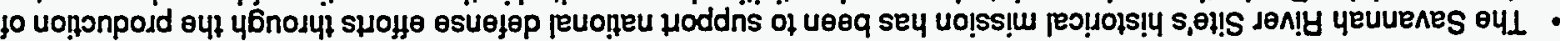

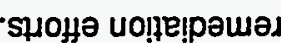

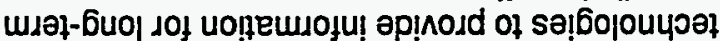

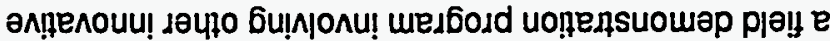

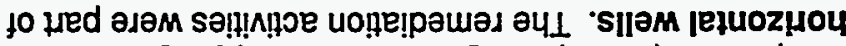

ul!m bu!dd!ns d!̣ n!!s u! bu!sn (so0 N) spunodwos

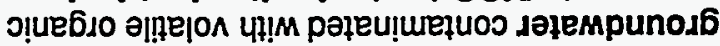

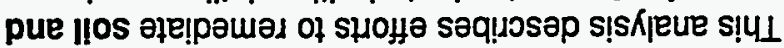

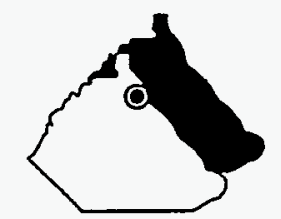

eu!jodes yłnos 'uөy!t Eอג $\forall W / H$

әIS dәn!บ yеuนenes

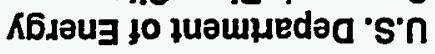

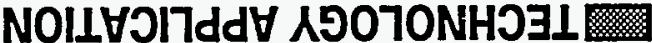




\section{Contaminant Locations and Geologic Profiles}

Metal-degreasing solvent wastes were sent to the A-014 outfall and, via the process sewer, to the M-area settling basin. Data from hundreds of soil borings, groundwater monitoring wells, and a variety of other investigative techniques has established a welldocumented VOC plume in both the vadose and saturated zones.

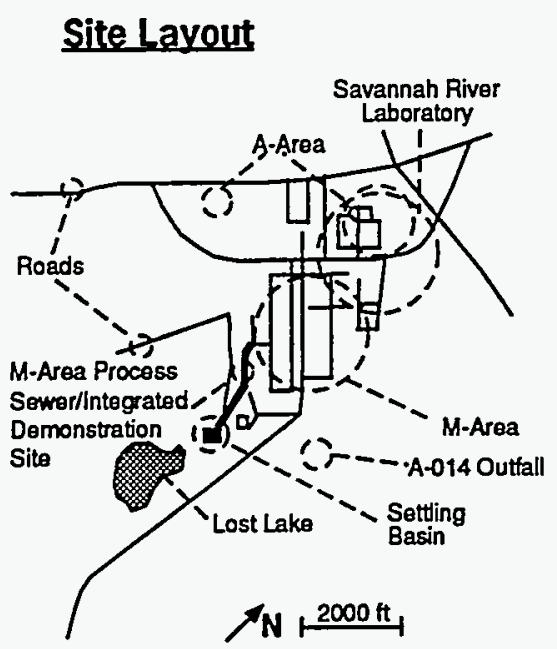

\section{TCE Groundwater Plume (Top View)}

Data from 15 feet bolow water
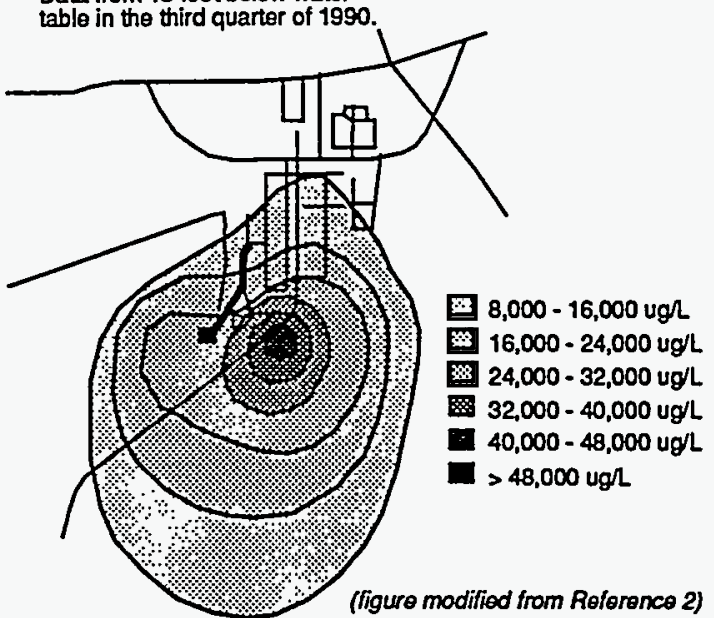

\section{TCE Concentrations in Soil [West-East Cross-Section]}

Concentration and lithology data from 1991 along an approximately $200 \mathrm{ft}$ cross-section across the integrated demonstration site. Concentration contours of TCE in sediments are based on analysis of over 1000 sediment samples. Layering of contamination occurs in clay zones.

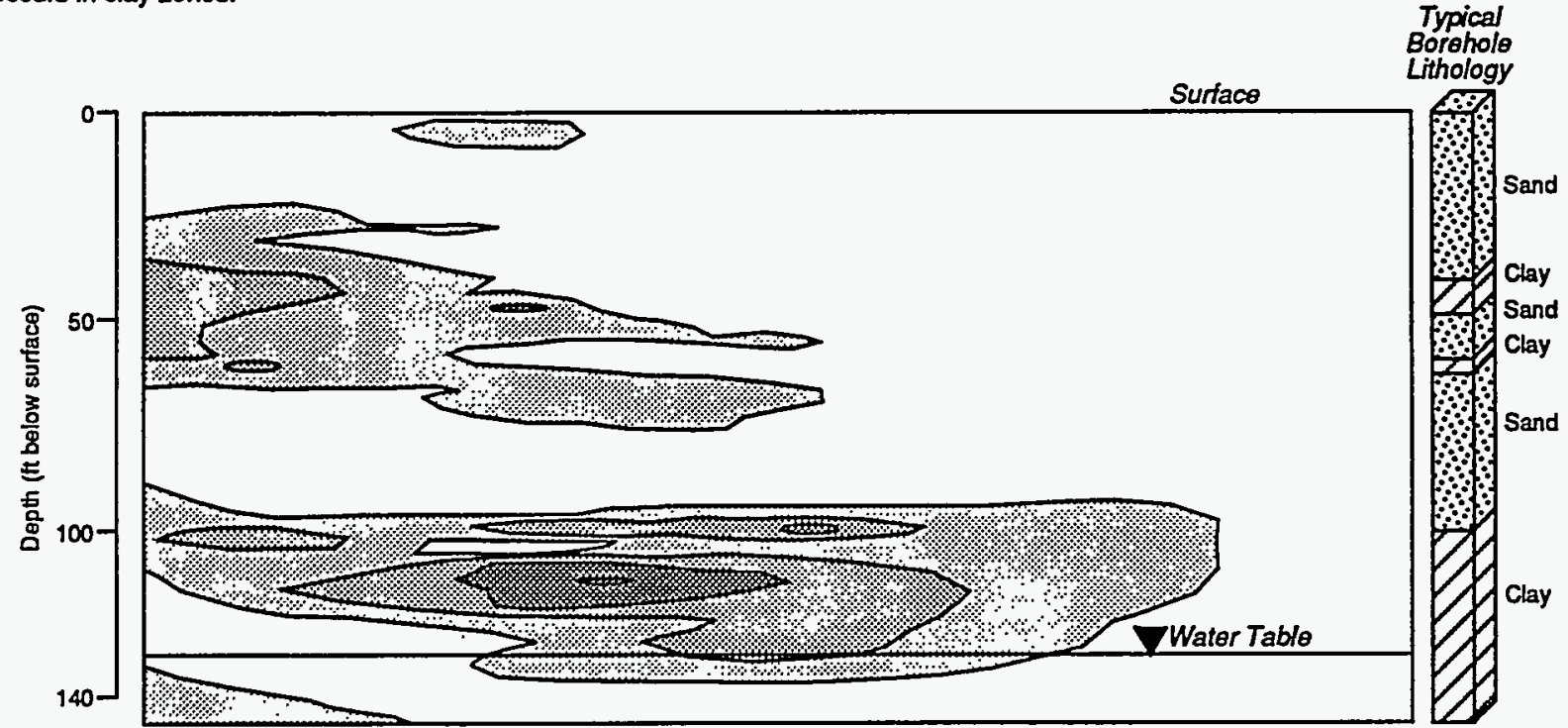

(figure modified from Reforence 2)

\section{Legend}

soil concentrations 100 to 1,000 ugh 5,000 to 10,000 ugh in ug/L 1,000 to $5,000 \mathrm{ug} / \mathrm{L}>10,000 \mathrm{ug} / \mathrm{L}$ 
Contaminant Locations and Geologic Profiles (Continued) Hydrogeologic Units

Aquifer

Unit

Vadose Zone

Description

Poorly sorted mix of sand, cobbles, silt \& clay

Moderate to well sorted, fine to medium sand containing some pebbles; $13 \%$ silt \& clay.

Moderately to well sorted medium sand; $18 \%$ silt \& clay.

Water Table Unit

Moderate to well sorted fine sand with some calcareous zones; $25 \%$ silt \& clay; $14 \%$ silt and clay beds.

Upper Well sorted fine to medium sand; $16 \%$ silt \& clay; $7 \%$ silt \& clay beds.

Lost Lake Aquifer

Discontinuous clay bods containing $70 \%$ sitt \& clay

Lower

Moderate to well sorted medium sand; $17 \%$ silt \& clay; $7 \%$ silt \& clay beds.

Crouch Branch

Confining Unit

Clay, clayey silt, and poorly sorted fine to coarse, clayoy sand: $62 \%$ silt 7 clay: contains 2 major clay layers the lower of which is $10-56 \mathrm{ft}$ thick and is the principal confining unit for lower aquifer is the prin

Crouch Branch Aquifer

Very poorly to well sortad, medium to coarse sands; $5 \%$ sand $\&$ clay beds; an important production zone for water supply wells in the $M$ Area.

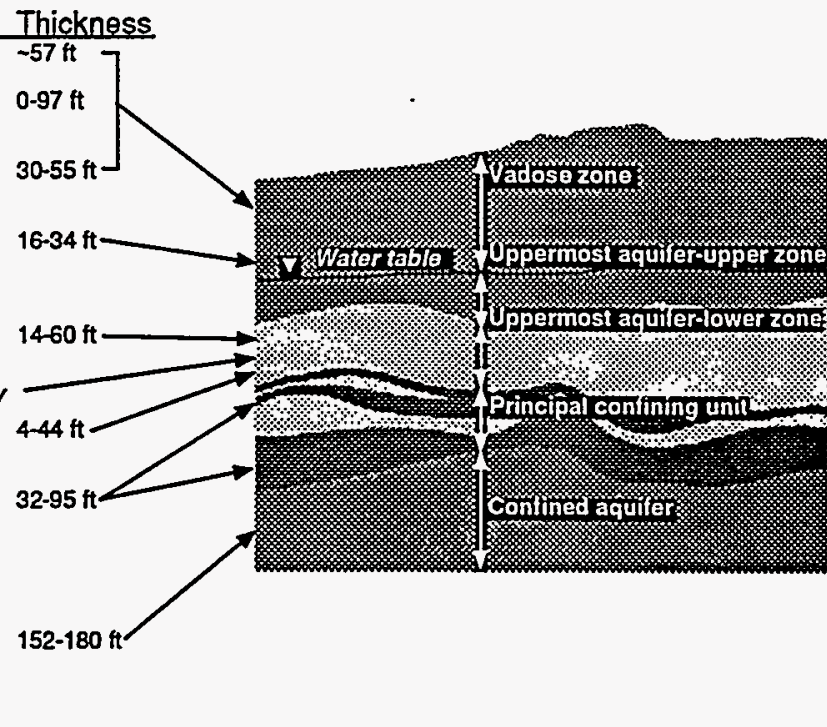

\section{Site Conditions}

- The AM-Area is approximately one mile inward from the northeast boundary of the 300 square mile Savannah River Site. Adjacent to the site boundary are rural and farming communities.

- The horizontal well site is located in the southwestern corner of the M-Area and it encompasses the M-Area settling basin, the abandoned process sewer leading to the basin, and the outfall A-104.

- The Savannah River Site includes a complex hydrogeology arising from heterogeneities in the multilayer aquifer system and discontinuous sand \& clay layers.

\section{Vadose Zone and Upper Aquifer Characteristics}

Schematic Diagram showing relationship between clay layers and hydraulic features.

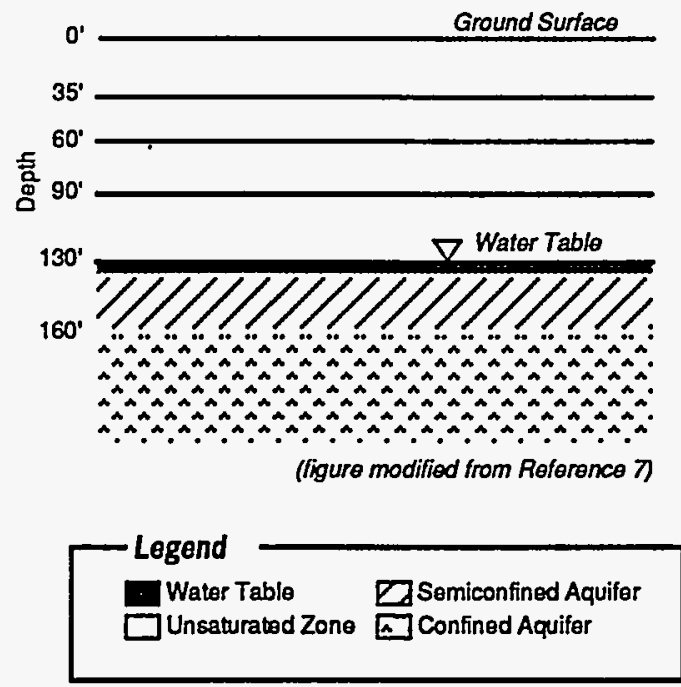

- Sediments are composed of sand, clay and gravel.

- Clay layers are relatively thin and discontinuous, with the exception of the clay layers at 160 foot depth, and a thicker zone of interbedded clay and sand found at 90 foot depth.

- Water table is approximately 135 feet below grade.

- A moderate downward gradient appears to exist beneath the M-Area. Vertical flow rates have been estimated to be 2 to 8 feet per year.

- Radial flow outward from a groundwater plateau surrounding most at the AMM-Area exists. Flow is approximately 15 to 100 ftyear. 


\section{TREATMENT SYSTEM}

\section{Overall Process Schematic}

- Air injected through lower

horizontal well, below the water table.

- Air/contaminant mixture extracted from upper horizontal well, above water table.

- Off-gas treatment available for long-term remedial operation.

- Horizontal wells 1 and 2 used in the in situ air stripping demonstration.

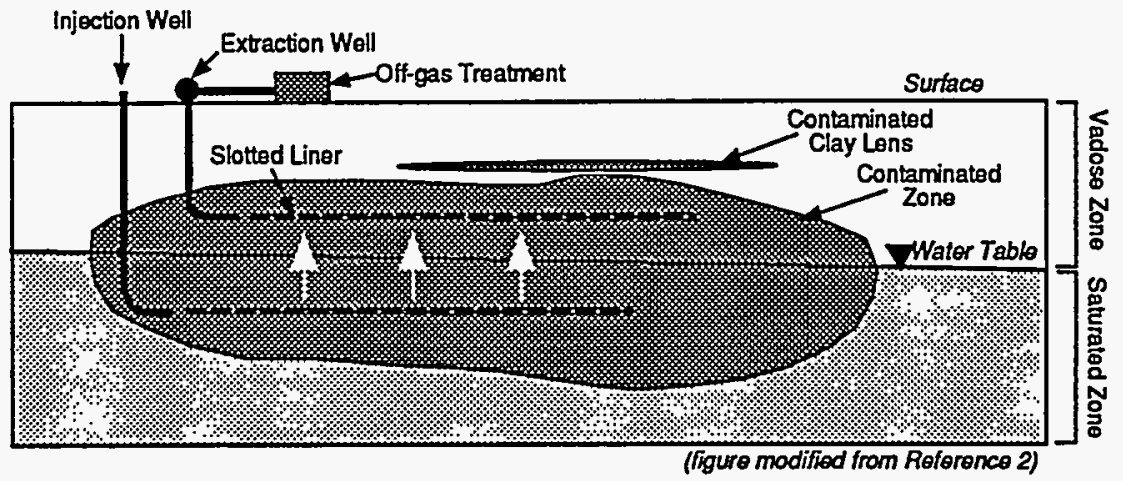

\section{Horizontal Wells Layout}

- Seven horizontal weil have been installed using four different installation methods.

- Wells 1 \& 2 and wells $3 \& 4$ are paired wells (subparallel in the subsurface, one in the vadose zone and one in the saturated zone) targeting contaminated sands.

- Wells $6 \& 7$ are paired wells (parallel in the subsurface, both in the vadose zone) targeting contaminated sands and clays beneath the closed disposal basin.

- Well 5 has surface well heads at both ends and is installed through contaminated clays.

- Wells $3 \& 4$ and wells $6 \& 7$ have not been used since installation
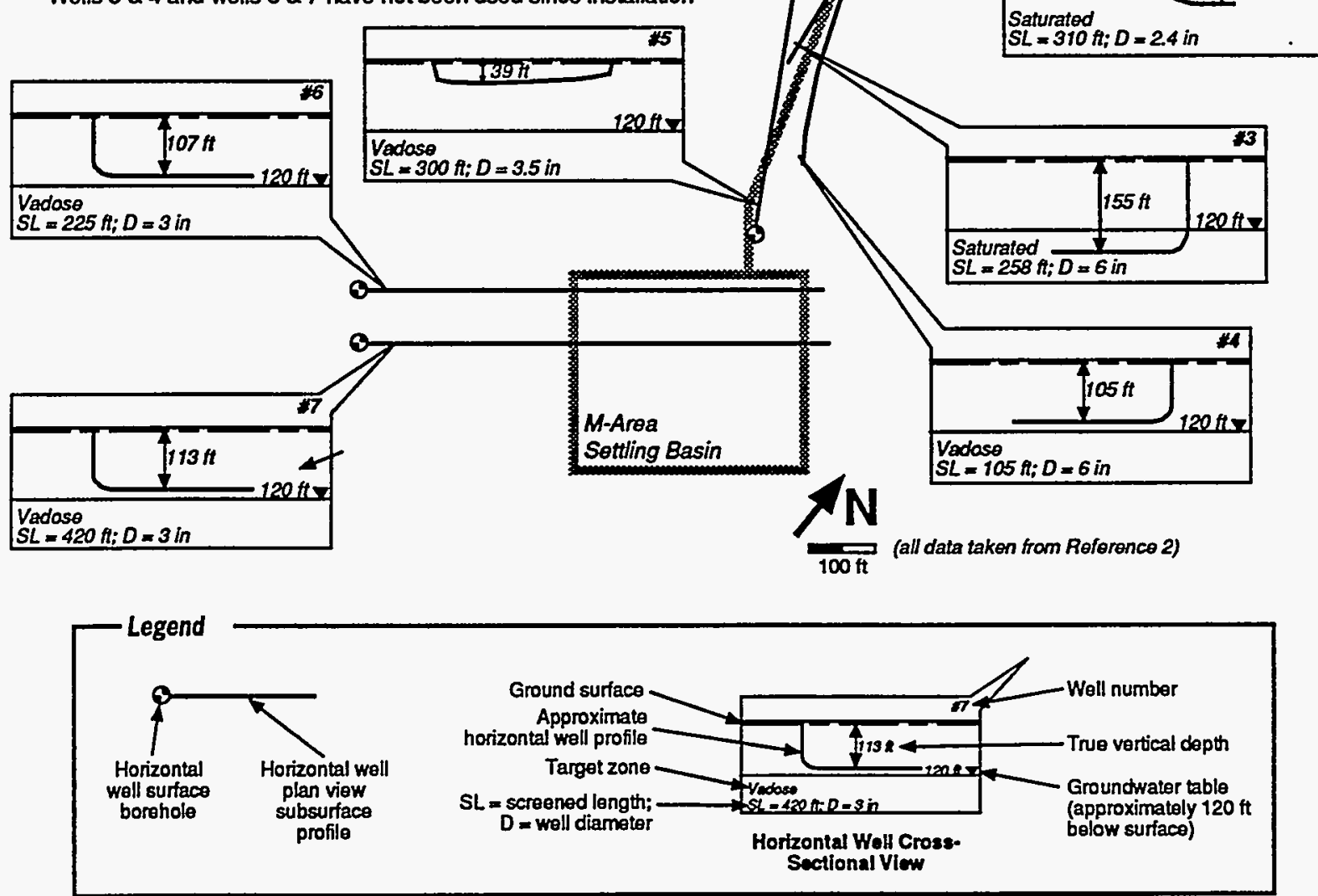
Injection, Extraction, and Offgas Treatment

\section{Injection}

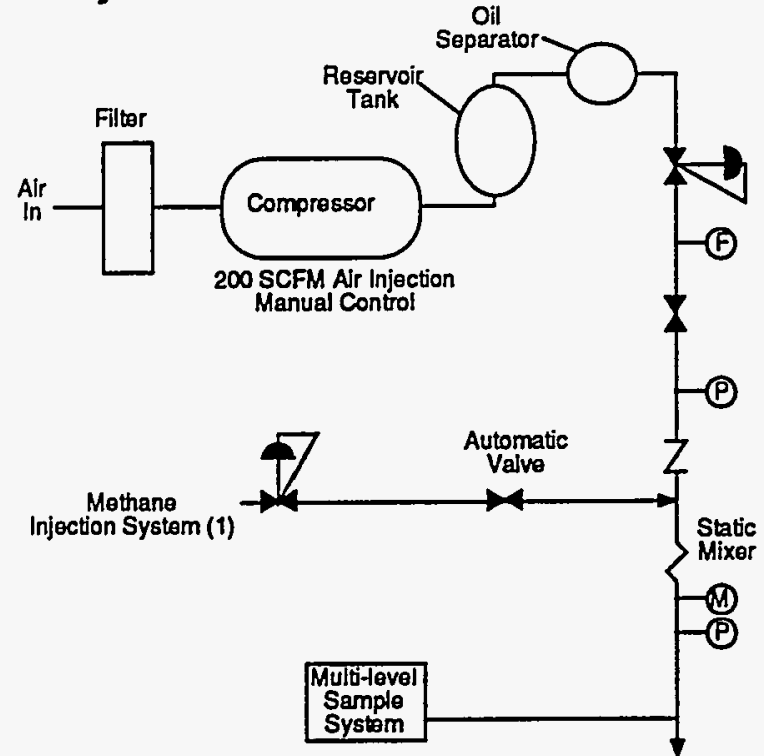

injection to Horizontal Well

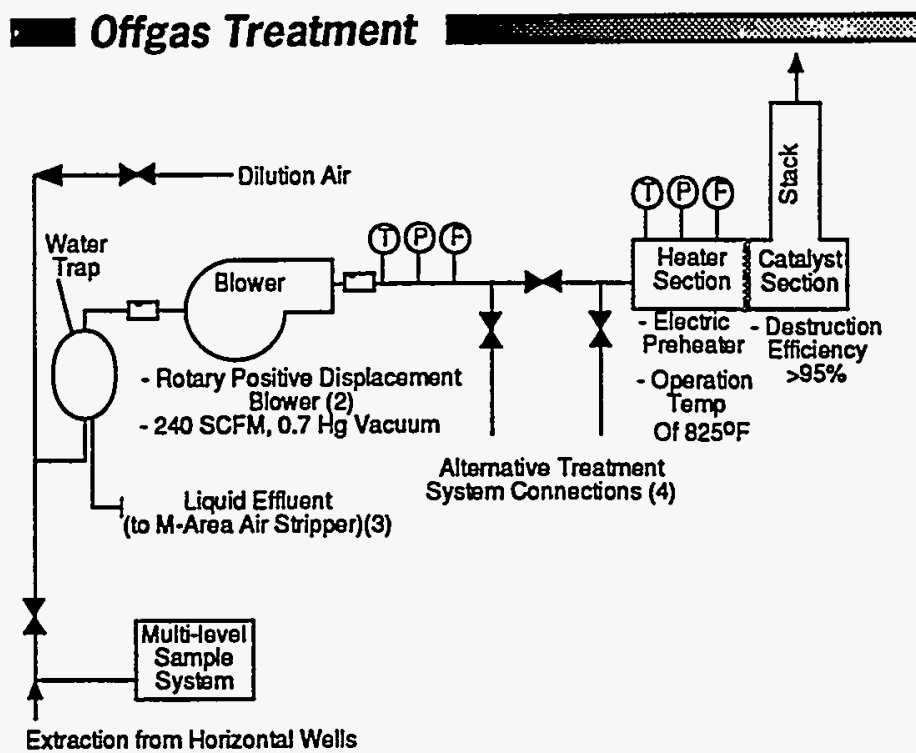

Extraction from Horizontal Wells

Notos:

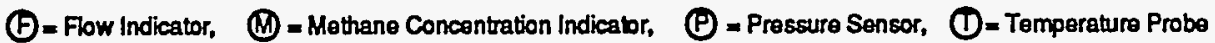

1. A PIO controller is used, calibratad based on \% of LEL of mathane.

2. Extraction systom is limitad by pumping capacity of extraction well to a maximum of $300 \mathrm{SCFM}$ at $10^{\circ} \mathrm{Hg}$.

3. Water trap removes debris and moisture from airstream. System inciudes a daytank to drain water from separator for

ultimato treatment at $M$-Area air stripper.

4. Demonstration released VOCs directly to the atmosphere. Offgas treatment required for long-term remediation.

\section{Generalized Horizontal Well}

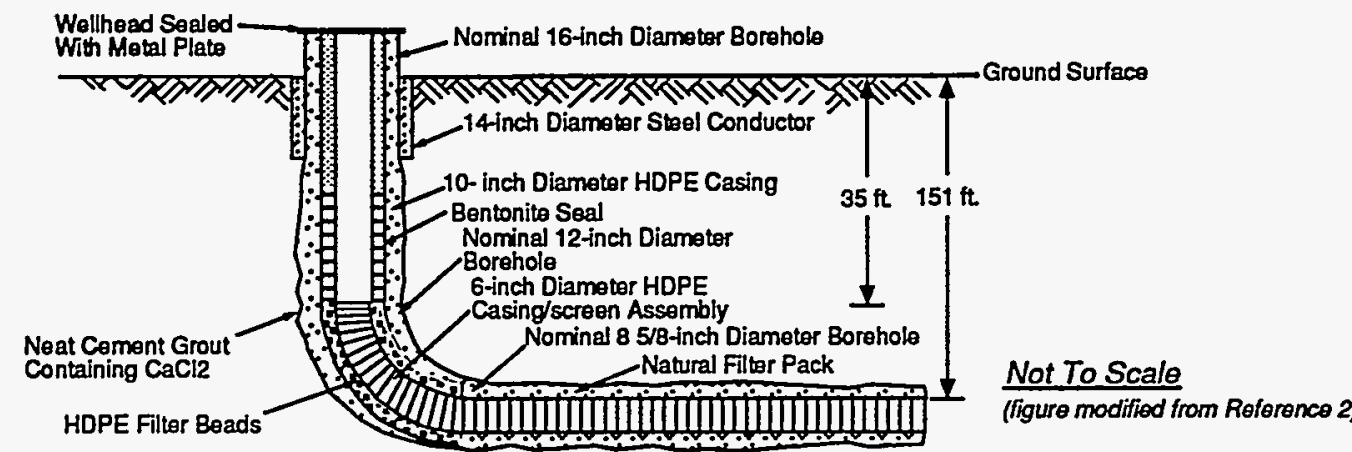

\section{Well Installation Techniques}

Four different well installation techniques were used during the demonstration:

1. Petroleum Industry Technology. A short-radius mud rotary technology. Vertical entry holes with a 35 foot radius for the curved section. Used non-rotating, curved drill quide, fexible drive pipe, an orientation assembly, and a stabilized straight-drilling assembly. Whip stocks used in curved section. Drilling fluids used. (wells 182)

2. Hybrid Potroleum Industry/Utility Industry Tochnology. Modified mud rotary system with bottom hole assembly comprised of a survey tool, steerable downhole motor, and an expandable wing drill bit. Drilling fuids used. (wells 3\&4)

3. Utility Industry Compaction System. This technology yielded a well head at initial and terminal points of the bore hole. Downhole drill assembly consisted of a wedge-shaped drilling tool, a steering tool, and a flexible sub -assembly attached to the drill string. Advanced by compaction, forcing cuttings to the borehole wall. Reduced volumes of water introduced as cooling/drilling fluid. (well 5)

4. Utility Industry River Crossing. Based on mud rotary system used to drive a downhole drill assembly, including a drilling tool, hydraulic spud jet with a 2 degree bend to provide directional drilling. Steering system was a magnetic guidance tool. A guar gumbased drilling fluid used. (wells 6\&7) 
PERFORMANCE

Performance Objectives

- Demonstrate proof of principle for air sparging using horizontal wells during a fixed, limited period of time permitted for the demonstration activity.

- Document substantial progress towards achievement of Groundwater Protection Standards (GWPS) established as part of a RCRA permit for the M-Area. The GWPS are based on EPA's Maximum Contaminant Levels (MCLs) of $5 \mathrm{ppb}$ for TCE and PCE and $200 \mathrm{ppb}$ for TCA.

- Reduce the contaminant concentrations in source areas so as to be able to achieve cleanup goals within 30 years.

- Demonstrate innovative characterization and monitoring technologies.

- Use of Integrated Demonstration Program site as an innovative technology education and training facility.

- Ensure that research, development, demonstration, and educational activities do not adversely impact remediation.

\section{Treatment Plan}

The M-Area HWMF RCRA Part B permit allows for ongoing and planned activities for vadose zone and groundwater remediation. Technology demonstrations at the IDP augment the M-Area HWMF program by addressing vadose zone contamination. Operation of one of the paired horizontal well systems will be part of full-scale M-Area remediation efforts.

The overall long-term environmental restoration strategy for the AMM-Areas involves an integrated approach containing three major elements. Only the larger AMM air stripping effort is fully detailed in this analysis:

Operation of pump-and-treat systems to hydraulically contain contaminant plumes and remove contaminant mass from groundwater.

One 600 GPM capacity air stripper treats an average water flow of 510 GPM drawn from 11 extraction well throughout the AM area; a second stripper treating an average of $55 \mathrm{GPM}$ from 1 extraction well near the Savannah River Laboratory in the A-Area.

- Further characterization of nature and extent of contamination with increasing focus on dense nonaqueous phase liquid (DNAPL) contamination.

Characterization and monitoring emphasized: minimally invasive techniques; real-time, in situ sample analysis; optimization of data from a single borehole; and to use new physicalchemical processes to improve sample analysis. Monitoring technologies included downhole flow and temperature sensor, cone penetrometer systems, geophysical systems, multilevel samplers, and real-time field analytical instruments.

Development, demonstration and implementation of technologies to supplement pump-andtreat efforts with increasing focus on source area, DNAPL and vadose zone remediation.

Technology demonstrations at the site have included characterization and monitoring, directional drilling, in situ air stripping, in situ bioremediation, in situ soil heating, and off-gas treatment. Off-gas treatment technologies have included portable catalytic system used to treat VOC-contaminated off-gas streams, as well as themal desorption and recycle/recovery systems used, recovering contaminants from carbon filters in off-gas treatment.

\section{Initial Process Optimization Efforts}

\footnotetext{
- In Situ Air Stripping

- Initial phase consisted of vacuum extraction of vadose zone gases, followed by air sparging, simultaneous air injection into the saturated zone and vadose zone extraction.

- Horizontal wells 1 and 2 were used for the in situ air stripping demonstration.

- Parametric studies of air injection rates and temperatures were conducted between July and December, 1990.

- Helium tracer was used to determine injected air mass balance.
}

- In Situ Bioremediation
- Nutrient injection and concurrent vadose zone extraction
carried out in horizontal wells 1 and 2 .
- Designed to enhance air stripping methods, resulting in
decreased contaminant concentration in groundwater and
enhancing remediation of fine-grained sediments
- Based on stimulation of indigenous organisms to
biodegrade TCE, producing water and carbon dioxide.
- Demonstration included steady and pulsed injection of
air/methane blend ( $1-4 \%$ methane).
- Nitrous oxide and triethyl phosphate added for
biodegradation optimization.




\section{Operational Performance}

- In Situ Air Stripping Demonstration showed five fold increase in VOC removal efficiency compared to the use of vertical injection and extraction wells.

- Air injection into Well 1 varied from at 65,170 , and 270 scfm.

- Vacuum extraction from Well 2 ranged from 550 to 600 scfm at 10 to 11 inches $\mathrm{Hg}$.

- Removal capabilities - 16,000 pounds of VOCs removed from vadose zone and groundwater over the 139-day duration of the in situ air stripper demonstration.

- System operated at $90 \%$ utility with shutdowns for repairs and maintenance less than $10 \%$ of the time.

\section{Treatment Performance}

\section{Effects on Vadose Zone Contaminants}

- Substantial changes in groundwater VOC concentrations measured during demonstration.

- Most monitoring wells at site exhibited lower concentrations of contaminants and increases in microbial numbers and metabolic activity during the air injection period.

- Post-demonstration sediment data indicates that almost all contaminants in sediment in the vadose zone were removed primarily due to microbial activity during later phases of remediation.

\section{Removal Data}

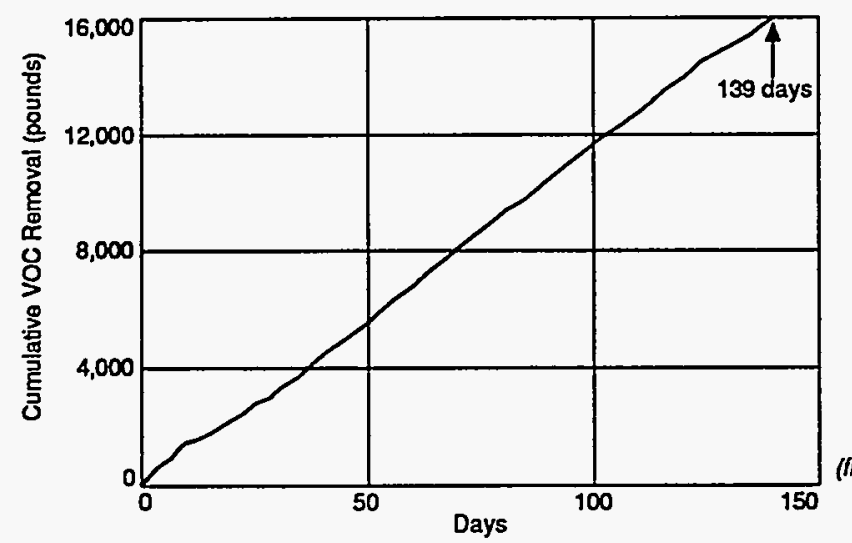

\section{In Situ Air Stripping VOC Extraction Rates}

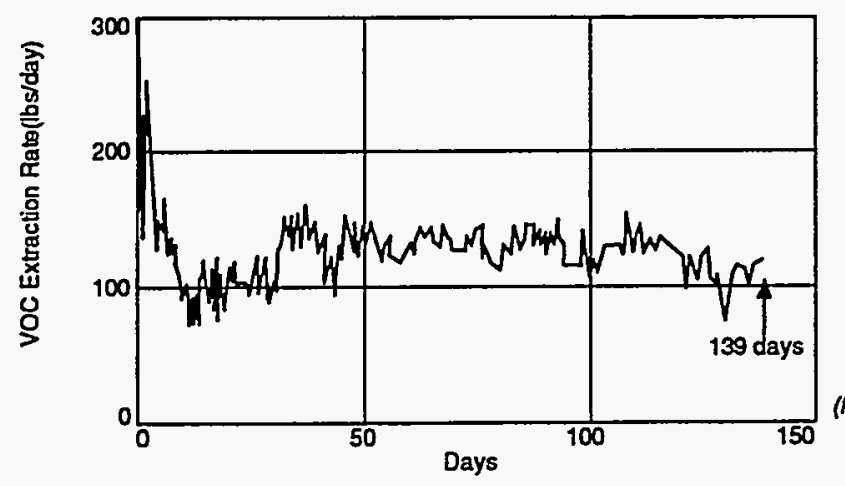

- 139 day demonstration removed nearly $16,000 \mathrm{lbs}$ of VOCs.

- Soil vapor extraction (without air injection) removed contaminants at a rate of $109 \mathrm{lbs} /$ day.

- Combined injection and extraction increased the removal rate to $130 \mathrm{lbs} /$ day.

(figure modified from Relerence 6)

- Contaminant removal rate ranged between 100 and $140 \mathrm{lbs} /$ day over most of the 139 days.

- Vacuum extraction removed an estimated $109 \mathrm{lbs} /$ day while air injection resulted in an additional $20 \mathrm{lbs} /$ day of VOC removal. 
- A cost study (Reference 4) was conducted that compared in situ air stripping with horizontal wells against the conventional cleanup technologies of combined pump and treat and soil extraction. A comparison of costs indicated that in situ air stripping can remove VOCs for approximately $60 \%$ of the cost of conventional methods. Detailed capital and operating costs taken from the study for the in situ air stripping application are presented below.

\section{Capital and Operating Costs}

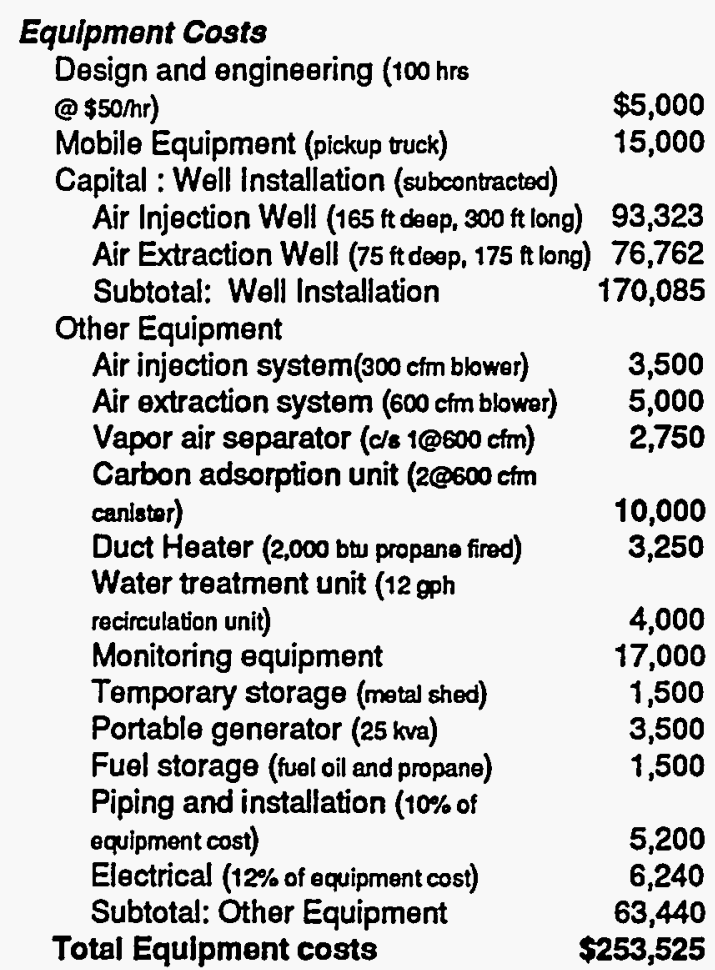

\section{Site Costs}

Site Costs (set up and level area) $\quad \$ 5,000$

Total Site Costs

$\$ 5,000$

\section{Labor Cost}

Mobilize/demobilize (based on 200 hrs

sot up \& bar down)

Technician -2

Laborers --2 $\quad 10,000$

Oversight engineer $-1 \quad 12,000$

Per diem $\quad 3,600$

Monitoring/maintenance crew (139

deye $(2$ hrsdday)

Technician - $1 \quad 8,340$

Oversight engineer $-1 \quad 16,680$

Total Annual Labor Costs $\$ \$ 62,620$

\section{Consumable Costs}

Carbon recharge (2.23 lb carbon/b voc) $\quad 101,688$

Fuel oil - diesel @ $10 \mathrm{gph} \quad 35,362$

Lubricants $\quad 6,950$

Deionized water $\quad 3,336$

Chemical additives $\quad 6,950$

Maintenance supplies $\quad 3,475$

Total Annual Consumable Costs $\$ \$ 157,761$

Notes:

1. Consumable supplies: Recycled carbon, $\$ 2.85 / \mathrm{b}$.; Diesel fuel, $\$ 1.06 /$ gal; Lubricants, $\$ 50 /$ day; Deionized water, \$0.10/gal; Chemical additives, \$50/day; Maintenance supplies, \$25/day.

2. Offgas treatment costs assume conventional carbon adsorption. However, demonstration did not include offgas treatment. Costs may be reduced more by installation of a higher efficiency offgas treatment system. 


\section{Cost Analysis for In Situ Air Stripping}

- A study of cost effectiveness of in situ air stripping (Ref. \#4) illustrated that equipment costs drop to a smaller percentage of total system costs when capital costs are annualized over 10 years as shown in the pie chart. Based upon an annual extraction rate of $33,612 \mathrm{lbs}$ VOCs and a total VOC quantity of $16,000 \mathrm{lbs}$, total costs per pound of VOC removed were calculated at Savannah River as follows:

\begin{tabular}{ll}
\multicolumn{2}{c}{ Cost/Lb of yoc Remoyed } \\
\hline \\
Equipment & $\$ 1.51$ \\
Site & $\$ 0.31$ \\
Labor & $\$ 3.91$ \\
Consumables & $\$ 9.86$
\end{tabular}

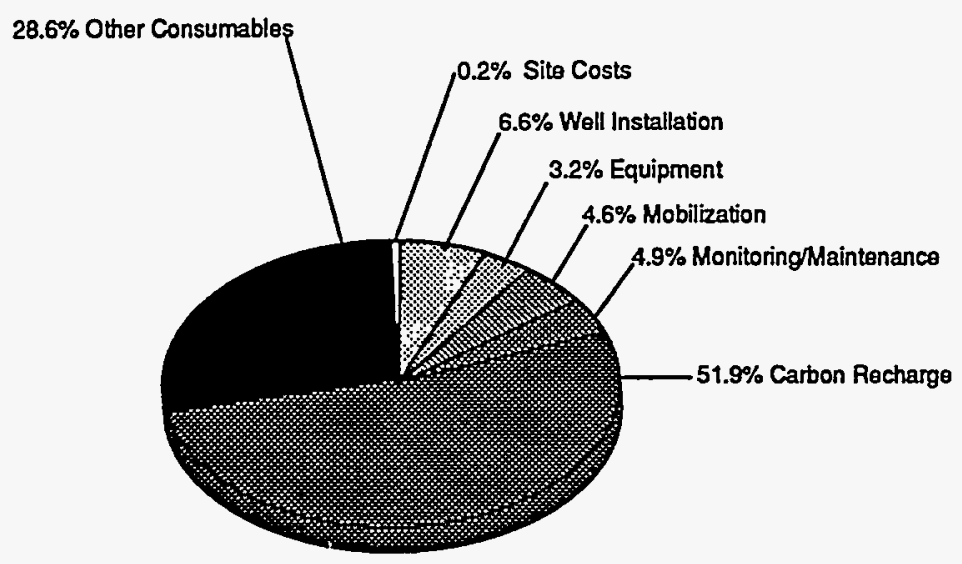

Total $\$ 15.59$

- For the same cost study, carbon adsorption was included for offgas treatment. However, a more highly engineered offgas treatment system can be expected to reduce the annual costs substantially.

\section{Cost Analysis for Horizontal Well Installation}

- Costs for installation of horizontal wells is much higher than costs for installation of vertical wells (approximately 10 times greater using the petroleum industry, 35 foot radius top-drive technique; approximately $\$ 360$ per foot).

- Some horizontal drilling techniques can be expected to be far less expensive, particulariy at shallower depths.

- The $\mathbf{4 0}$ to $\mathbf{5 0}$ foot depth indicated a critical distinction between drilling technologies for horizontal wells.

- Shallower than $\mathbf{4 0}$ to 50 , feet the utility industry compaction or river crossing techniques may be used with a cost as low as $\$ 50$ per foot.

- For depths greater than $\mathbf{4 0}$ to $\mathbf{5 0}$ feet, the petroleum industry technology and its hybrid petroleum/utility river crossing technology can be used. Costs for the deeper horizontal wells range from $\$ 360$ per foot up to $\$ 700$ per foot.

- As drilling companies gain experience with horizontal wells, the costs are expected to decrease.

- Despite the high drilling costs, if carbon adsorption is used as the off-gas treatment, it contributes the largest part to the total remedial system cost. 


\section{REGULATORY/INSTITUTIONAL ISSUES}

- The M-Area settling basin and excavated sections of the process sewer line were remediated through a RCRA closure completed in 1990, and certified by the State of South Carolina in 1991.

- Permitting for the demonstrations, including the South Carolina Department of Health and Environmental Control (SCDHEC) Air Quality Control (AQC) permit waiver and Underground Injection Control (UIC) permits, had expired as of September, 1993.

- Future remediation and demonstration activities will require National Environmental Policy Act (NEPA) review and appropriate SCDHEC permits.

- For remedial activities, the M-Area HWMF RCRA Part B Permit must be reviewed to determine if a permit modification is necessary.

- Any future vacuum extraction will not require UIC permitting, however, if either in situ sir stripping or in situ bioremediation is conducted, UIC issues need to be addressed. UIC permits are issued by South Carolina Board of Drinking Water Protection under the Safe Drinking Water Act.

- If future remedial activities involve bringing contaminated groundwater to the surface, a wastewater permit may be required from SCDHEC. If treated groundwater is discharged to a surface water, an NPDES permit or permit modification will be required.

- An AQC permit was not required for the demonstrations, but will be required for full scale remediation.

\section{SCHEDULE}

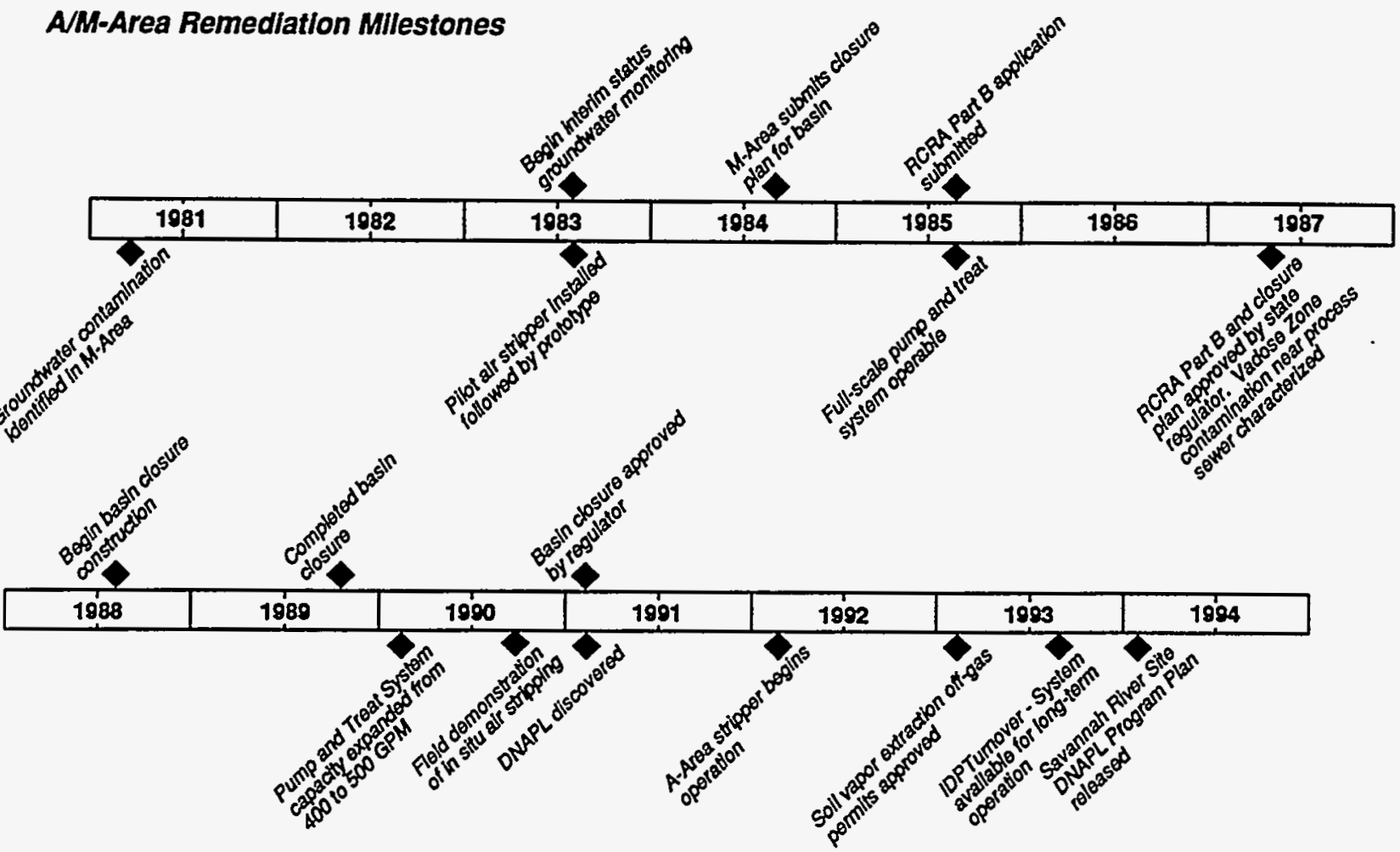




\section{Implementation Considerations}

- During installation of horizontal well 1, the drill string became stuck, and was abandoned downhole (approximately the bottom 360 feet of the well). To salvage the hole, a perforated steel tube was threaded into the borehole to act as the screen zone of the well. The result was loss of a considerable length of well screen for use in remedial efforts.

- Six pressure sensors have been installed along horizontal wells 1 and 2 to measure the efficiency of each well along its length. The measurements were spaced at approximately 60 foot intervals. Measurements indicated active extractioninjection along the entire length of the borehole. This type of monitoring is inexpensive and recommended.

- Drilling fluids, containing (at various times) bentonite, polymer, and lignosulfonate in fresh water were used to maintain borehole stability. Significant amounts of drilling fluids were lost to the formations. Methods to reduce fluid loss during horizontal drilling were investigated.

- The filter pack on all these horizontal wells is made up of natural formation solids, principally due to collapse around the borehole. This may diminish well efficiencies.

- During installation of horizontal well 5 , the well with two wellheads, two attempts were made to install the well screen. On the final attempt, fiberglass casing and 3.5 inch diameter and 0.010 inch slotted fiberglass well screen was used to alleviate polyvinyl chloride (PVC) screen failure during pull back.

- To lesson fluid loss in permeable zones observed during installation of 6 , an attempt was made to advance the washover pipe. However, the string broke when an attempt was made to retract the pipe. The abandoned washover string reduced the effective screen length from 400 feet to 230 feet.

- During well development at two of the horizontal wells, sand trapped in the borehole terminus reduced the effective screen length; one well was reduced by 5 feet, the second well was reduced by 15 feet.

- Horizontal vacuum extraction wells extract water from the vadose zone during operation - the vertical trajectory of the well must be planned to avoid plugging.

\section{Technology Limitations}

- Clay layers, because of their low permeability, are troublesome. However, these zones have significant levels of contamination. Heterogeneities in the subsurface, either due to stratigraphy or fractures, can result in preferential air flow pathways, resulting in less effective contact and remediation.

- By inducing water flow, in situ air stripping can accelerate a lateral or downward migration of contaminants in certain geologic settings. If clay layers or other geologic features constrict vertical flow, it may be necessary to use in situ air stripping in conjunction with a pump and treat system for hydraulic control.

- Due to the high cost of installing; horizontal wells, the selection of the location of the well becomes more important than for vertical wells.

\section{Future Technology Selection Considerations}

- Directional drilling of horizontal wells was demonstrated to assess its role in improving the efficiency of a remediation project. Remediation efficiency may be enhanced by increased surface area for reaction, similarity of borehole and contaminant plume geometry, borehole access to areas beneath existing facilities, and the ability to drill areas along facility boundaries to control plume migration. Direct comparison of vertical and horizontal vacuum extraction during the program confirmed the improvements from using horizontal wells.

- Successful in situ air stripping requires good contact between injected air and contaminated soils and groundwater. An optimal geologic setting would have moderate to high saturated soil permeability, a homogenous saturated zone, and sufficient saturated thickness. Vadose zone characteristics would be high permeability and homogeneity. Air stripping would be more effective in course-grained soil. 


\section{Future Technology Selection Considerations (Continued)}

- For in situ air stripping to be effective, the contaminants of concern must be strippable, that is mobile in and between all phases. Contaminants must have a dimensionless Henry's Law Constants greater than 0.01 , vapor pressures greater than $70.1 \mathrm{mmHg}\left(\right.$ at $25^{\circ} \mathrm{C}$ ), and soil/water partition coefficients ( $\left.K_{\infty d}\right)$ less than 1000 to be physically removable. Most light hydrocarbons and chlorinated solvents satisfy these conditions.

- Horizontal wells may provide for better contact with linearly-shaped contaminant plumes. In situ air stripping may be more effective with relatively thin plumes of contaminants.

This analysis was prepared by:

Stone \& Webster Environmental

Technology \& Services

245 Summer Street

Boston, MA 02210

Contact: Bruno Brodfeld (617) 589-2767

Assistance was provided by the

WESTINGHOUSE SAVANNAH RIVER COMPANY which suppliod koy information and reviowed report drafts.

for:

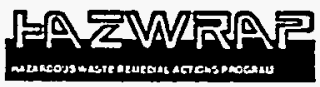

HAZARDOUS WASTE REMEDIAL ACTIONS PROGRAM Environmental Restoration and Wasto Management Programs

Cak Ridge, Tennessee $37831-7606$ managed by

MARTIN MARIETTA ENERGY SYSTEMS

for the

U.S. Department of Energy

under Contract DE-ACO5-84OR-21400

This analysis was funded by:

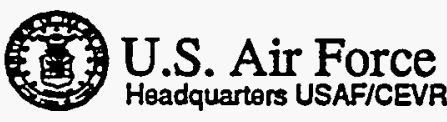

-.

\section{CERTIFICATION}

This analysis accurately reflects the performance and costs of the remediation:

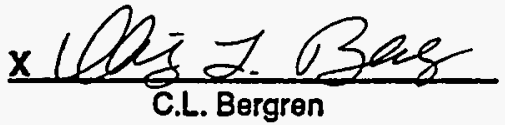

Westinghouse Savannah River Company

Environmental Restoration Department Manager Northern Ground Water Facilities

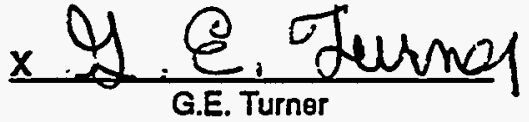

G.E. Turner

Department of Energy

Savannah River Operations Office

Environmental Restoration Division

Environmental Specialist 


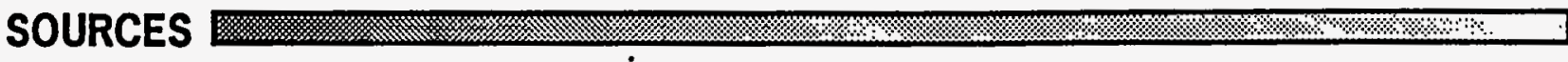

Major Sources For Each Section

Site Characteristics:

Treatment System:

Performance:

Cost:

Regulatory/lnstitutional Issues:

Schedule:

Lessons Learned:
Source \#s (from list below) 2, 3, 7 and 8

Source \#s 1, 2, 6 and 7

Source \#s 2 and 4

Source \# 4

Source \# 2 and 4

Source \#s 2, 4 and 8

Source \#s 2, 4 and 5

\section{Chronological List of Sources and Additional References}

1. Personal communications with C.A. Eddy Dilek, Westinghouse Savannah River Company, April 1994.

2. "Tumover Plan for the Integrated Demonstration Project for Cleanup of Contaminants in Soils and Groundwater at Non-Aid Sites", SRS, Science Applications International Corporation, September 7, 1993.

3. C.A. Eddy Dilek, et. al., "Post Test Evaluation of the Geology, Geochemistry, Microbiology, and Hydrogeology of the In Situ Air Stripping Demonstration Site at the Savannah River Site", Westinghouse Savannah River Company, July 1993.

4. J.D. Schroeder, et. al., "In Situ Air Stripping: Cost Effectiveness of a Remediation Technology Field Tested at the Savannah River Integrated Demonstration Site"; Los Alamos National Laboratory, June 1992.

5. "Cleanup of VOCs in Non-Arid Soils - The Savannah River Integrated Demonstration", U.S. DOE, WSRC-MS91-290, Rev. 1, 1991.

6. Looney, B. B., T. C. Hazen, D.S. Kaback, and C. A. Eddy, "Full Scale Field Test of the In Situ Air Stripping Process at the Savannah River Integrated Demonstration Test Site" (U), Westinghouse Savannah River Company, WSRC-RD-91-22, June 29, 1991.

7. Eddy, C. A., B. B. Looney, J. M. Dougherty, T. C. Hazen, and D. S. Kaback, "Characterization of the Geology, Geochemistry, Hydrology and Microbiology of the In-Situ Air Stripping Demonstration Site at the Savannah River Site" (U), Westinghouse Savannah River Company, WSRC-RD-91-21, May 1, 1991.

8. Preliminary Technical Data Summary M-Area Groundwater Cleanup Facility, DuPont - Savannah River Laboratory, October 1982. 


\section{TECHNOLOGY APPLICATION ANALYSIS}

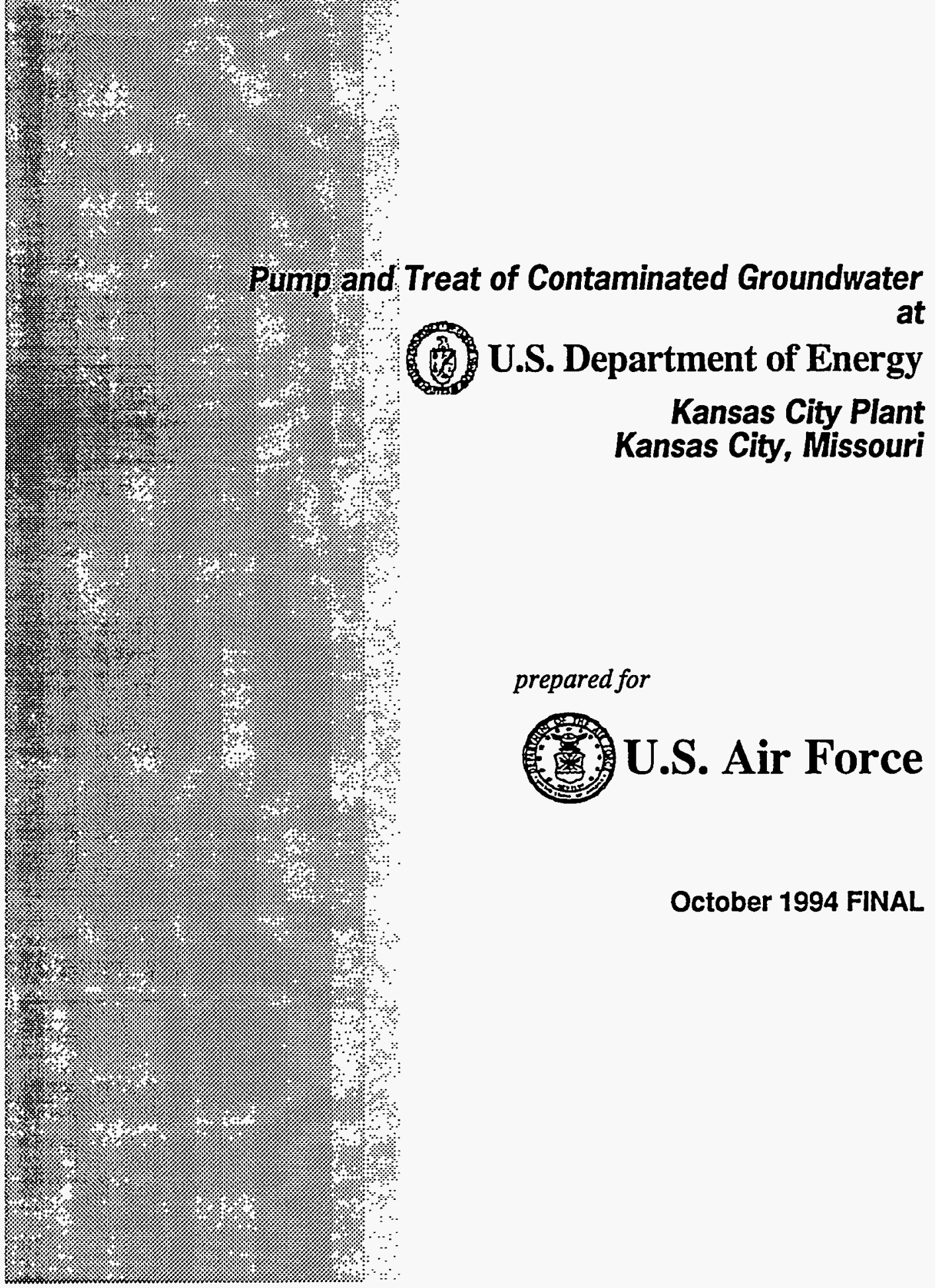


U.S. Department of Energy Kansas Clty Plant (KCP) A RCRA Corrective Action Site Kansas City, Missouri

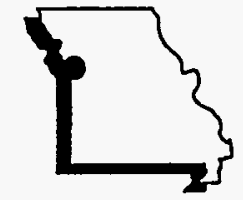

TECHNOLOGY APPLICATION

Page 1 of $13=$
This analysis covers an effort to pump and treat groundwater contaminated with volatile organic compounds (VOCs) by above ground advanced oxidation processes (AOPS). The treatment began in May 1988 and is currently ongoing. This analysis covers performance through February 1994.

\section{STTE CHARACTERISTICS}

\section{- Site History/Release Characteristics}

- The KCP is located within the Bannister Federal Complex approximately 13 miles south of downtown Kansas City, Missouri. The complex is bordered on the east by the Blue River and on the south by Indian Creek.

- Constructed in 1942 as an aircraft engine manufacturing facility, the KCP is part of the U.S. Department of Energy's (DOE) Albuquerque Operations Office. The Atomic Energy Commission, predecessor to the DOE, began production of components for nuclear weapons at the KCP in 1949. Subsequent defense related research and manufacturing operations resulted in the release of contaminants to the subsurface.

- A series of hydrogeologic investigations initiated in the early/mid 1980 s revealed elevated contaminant concentrations (primarily chlorinated VOCs) in soil and groundwater.

- A groundwater pump and treat system, the subject of this report, started operation in May 1988. That system was designed as an interim remedial measure to prevent further migration of VOC-contaminated groundwater while additional RCRA Facility Investigation (RFI) and Corrective Measures Study (CMS) efforts to define final site remedial measures were being performed. A low intensity Ultraviolet (UV)/Ozone $\left(\mathrm{O}_{3}\right) / \mathrm{Hydrogen}$ Peroxide $\left(\mathrm{H}_{2} \mathrm{O}_{2}\right)$ treatment system operated until May 1993 when it was replaced by a high intensity $U V / H_{2} \mathrm{O}_{2}$ system. The initial system was a demonstration of first-generation AOP technology; the replacement system is considered second-generation technology.

\section{Contaminants of Concern}

Contaminants identified as being of greatest concerm in grounctwater at the KCP are:

$$
\begin{aligned}
& \text { Tetrachloroethene } \\
& \text { Trichloroethene } \\
& 1,2 \text {-dichloroethenes } \\
& \text { Vinyl chloride }
\end{aligned}
$$

(PCE)

Other contaminants detected in soil or groundwater include aromatic and halogenated VOCs, petroleum hydrocarbons, PCBs and selected metals.

Arsenic, present at concentrations higher than drinking water standards, was determined to be

\begin{tabular}{|c|c|c|c|c|c|}
\hline Properties* & Units & PCE & TCE & 1,2-DCEs** & Chim \\
\hline Density & - & 1.62 & 1.46 & $1.25 / 1.27$ & 0.91 \\
\hline Vapor Pressure & $\mathrm{mmH}$ & 952 & 281 & 7 & 245 \\
\hline $\begin{array}{l}\text { Henry's Law } \\
\text { Constant }\end{array}$ & atmem $\mathrm{m}^{3} / \mathrm{mole}$ & 0.0259 & 0.0091 & $\begin{array}{l}0.0066 \\
0.0076\end{array}$ & 0.0144 \\
\hline Wator Solubility & $\mathrm{mgn}$ & 150 & 1,100 & $2,250 / 3,3500$ & 2,670 \\
\hline $\begin{array}{l}\text { Octanol -Water } \\
\text { Partition } \\
\text { Coefficient } K_{\text {ow }}\end{array}$ & - & 398 & 240 & $3 / 5$ & 24 \\
\hline $\begin{array}{l}\text { Organic Carbon } \\
\text { Partition } \\
\text { Coefficient } K_{\infty}\end{array}$ & - & 364 & 126 & $49 / 59$ & 57 \\
\hline - Properties at 2 & $0^{\circ} \mathrm{C}$ & & \multicolumn{3}{|c|}{ - Data presented for both cis and trans-isomers. } \\
\hline
\end{tabular}
the result of natural geochemical processes.

\section{Contaminant Properties}

Properties of contaminants focused upon during remediation are:

\section{Nature \& Extent of Contamination}

- Characterization of the nature and extent of contamination at the KCP evolved over a number of years of investigation and interim remediation. Thirty-seven solid waste management units were found to have contributed to three primary areas of groundwater contamination known as: the TCE Still Area, the Underground Tank Farm Area, and the Northeast Area/Outfall 001 Area.

- Groundwater contamination is largely confined within the KCP limits. However, chlorinated VOCs have migrated with groundwater along a backfilled stream channel to the Blue River northeast of the KCP.

- The vertical distribution and concentrations of VOCs in soil and groundwater suggest the potential presence of dense non-aqueous phase liquid (DNAPL) in several areas which contribute to groundwater contamination.

- The presence of numerous subsurface utilities/utility trenches, including building footing tile drains, have a significant impact on contaminant migration at the KCP site. These utilities act as sources of recharge water, preferential migration pathways, and collectors for contaminated groundwater. 
Remedial investigation field activities at the site have included:

- Borings and subsurface soil sampling - Monitoring well installation and groundwater sampling

- Groundwater elevation measurements

- Goophysical testing

- Hydraulic test

- Borehole packer testing

- Surface water sampling and elevation

measurements

- Groundwater modeling

Data from $\sim 200$ soil borings and $\sim 190$ monitoring/extraction wells were used to develop an understanding of subsurface conditions, including contaminant migration. Solected data from site studies have been used in this report to depict site conditions.
- Water source/sink assessment

\section{Site Layout (Plan View)}

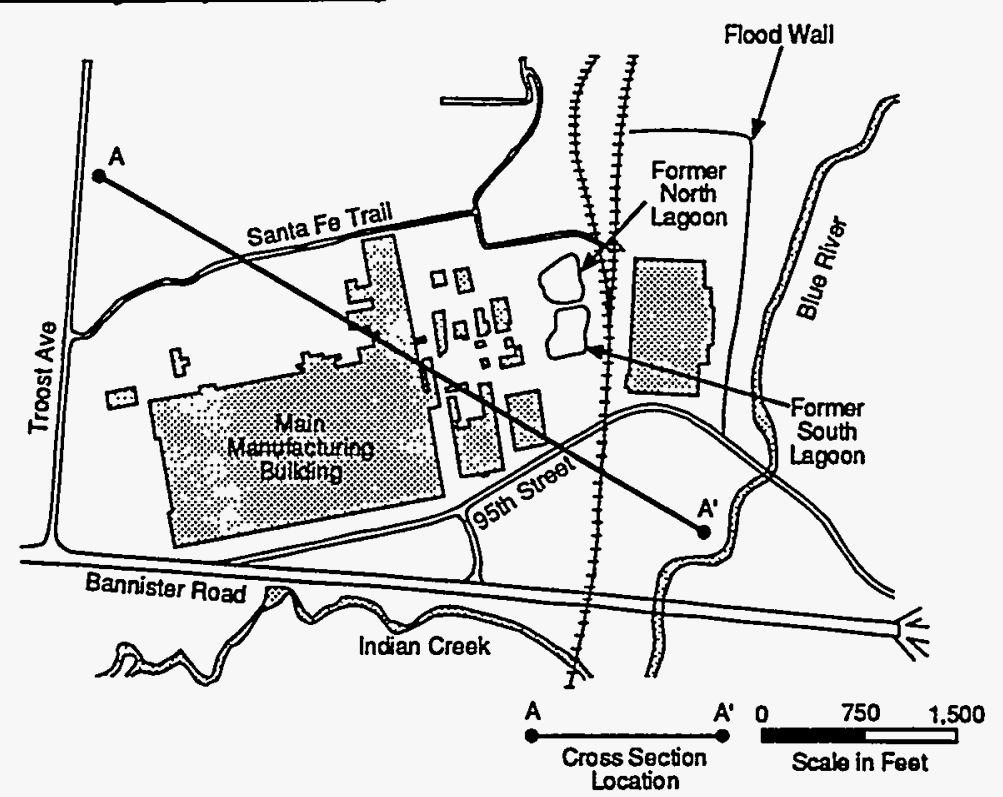

Horizontal Distribution of VOCs in Groundwater Generalized Representation (Plan View)

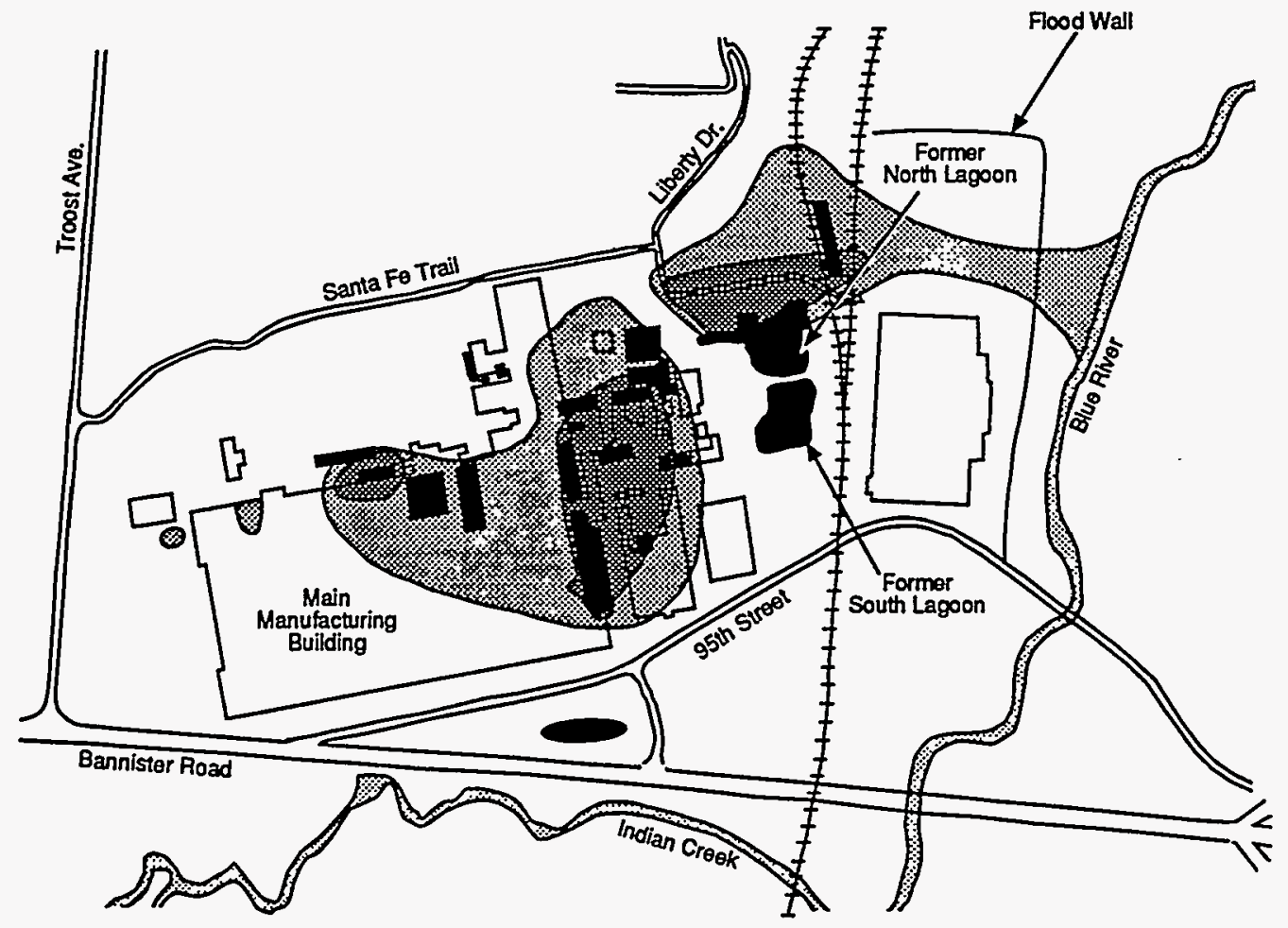

Scale in Feet

Groundwater Plume 5 ugl Total VOCs
Groundwate $>1,000$ ugh
Total Vods

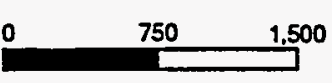




\section{Contaminant Locations and Geologic Profiles (Continued)}

Vertical Distribution of VOCs in Groundwater

- In general, concentrations of prime contaminants of concern in groundwater increase with depth in overburden soils at the KCP site. Dense non-aqueous - phase liquid(s) (DNAPL) may be present in some areas. The figure below, illustrating TCE concentrations in groundwater at one of the 3 primary contamination areas (the TCE Still Area), is representative of the vertical distribution of chlorinated VOCs at the KCP site.

- Alluvial deposits at the KCP site are under lain by bedrock consisting of alternating layers of sandstone and shale. A thin layer of sandstone (< 10 feet thick) immediately beneath the alluvium pinches out beneath the site. Packer testing performed on the shale indicated it was relatively impermeable. No bedrock migration of VOCs has been observed.

- Because the bedrock surface dips in the opposite direction as alluvial groundwater flow, additional monitoring wells were completed within the shallow sandstone at the request of EPA to monitor for the potential migration of VOCs. No VOCs or dissolved-phase contamination have been detected in these wells. Additionally, contaminant transport modeling predicted that VOCs (if present) would migrate at an average rate of $<1$ foot per year under worst-case conditions in the sandstone.
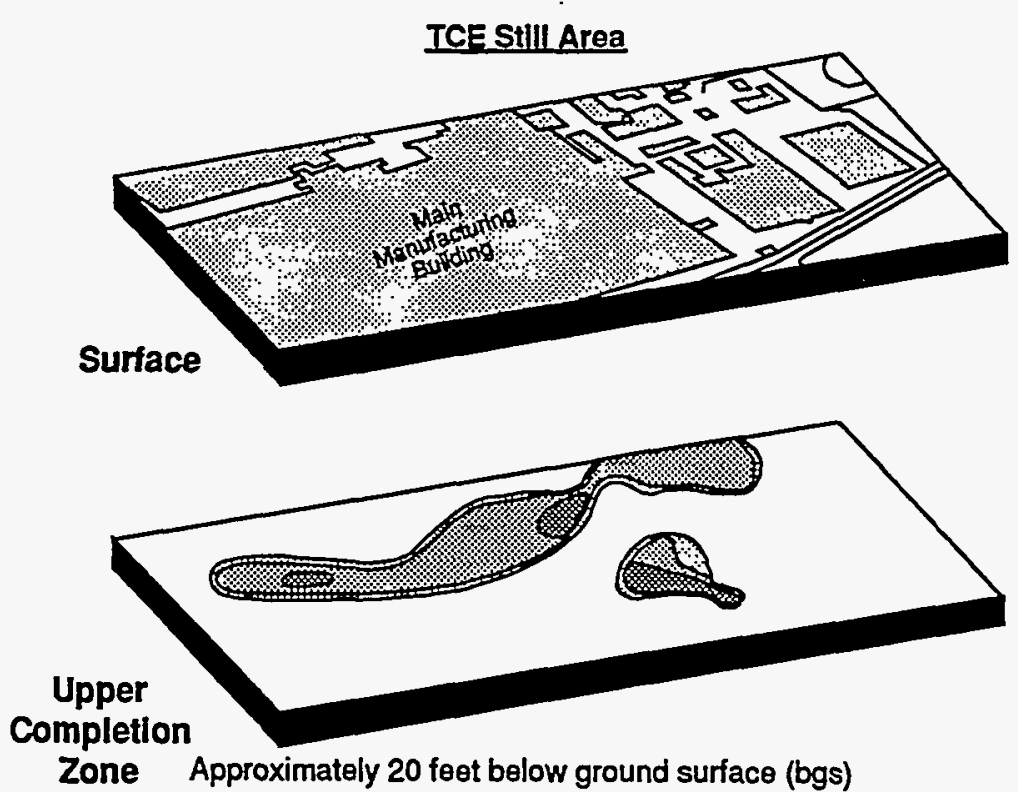

Zone Approximately 20 feet below ground surface (bgs)

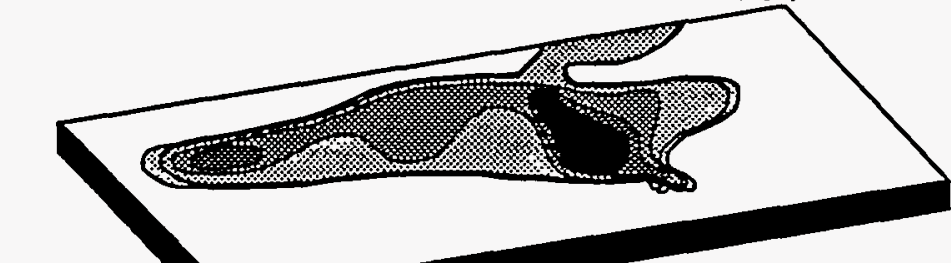

Lower

Completion

Zone Approximately 40 feet bgs
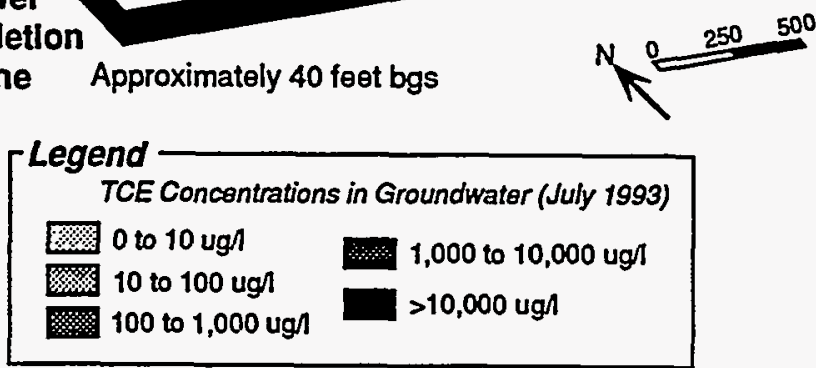

\section{Schematic Cross-Section of Bedrock and Alluvium at KCP}

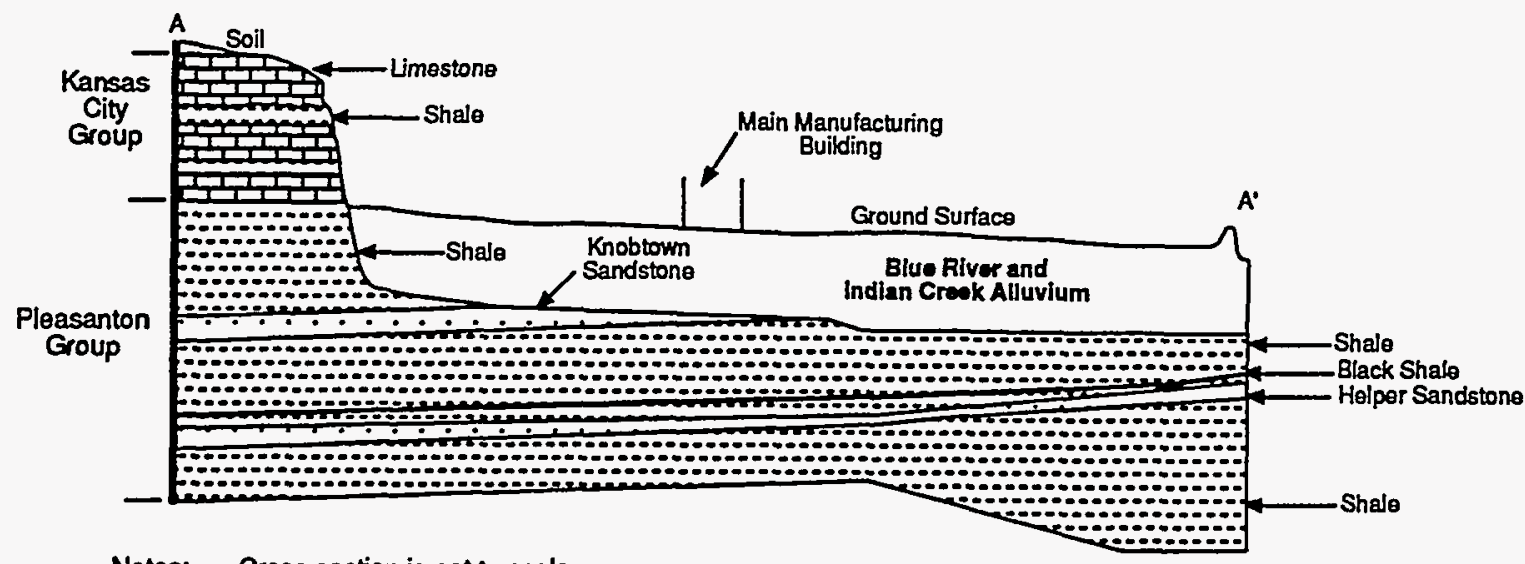

Notes: Cross section is not to scale.

Cross section location shown on site map (page 2). 


\title{
Location of Old Blue River Channel (Plan View)
}

The former Blue River channel, now filled, has a hydraulic conductivity an order of magnitude greater than the surrounding soil. This former river channel is serving as a preferential pathway for migration of contaminated groundwater from the Northeast Area/001 Outfall to the current location of the Blue River.

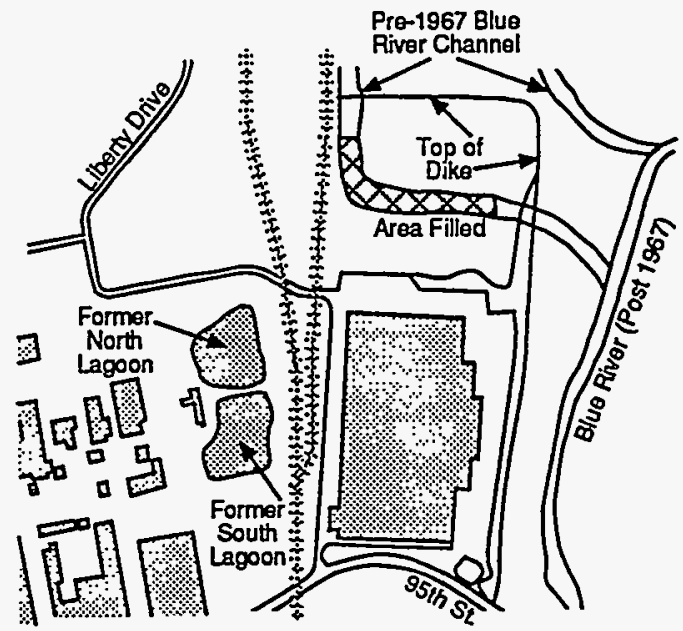

\section{Groundwater Sinks and Sources}

\begin{abstract}
Several site structures (in addition to the extraction wells and interceptor trench) serve as sinks/collectors for groundrater on the KCP site and impact contaminant migration. Groundwater drains include: the 001 Outfall Interceptor system [ $\sim 6,000$ gallons per day (GPD)], which is a collection system to prevent groundwater infiltration into an NPDES storm sewer, a sump for the building southwest of the former South Lagoon, building footer drains, and possibly the plant sewer lines. Building drains control the surtace of the water table in the vicinity of the Main Manufacturing Building.

In addition to recharge due to infiltrating precipitation, it is believed that leaking underground water and steam lines could be serving as a source of water to the subsurface. The KCP has initiated a study to quantify artificial sinks and sources of water in the subsurface at the KCP site.
\end{abstract}

\section{Site Conditions}

- The KCP is situated in the Blue River Valley about 800 feet above Mean Sea Level (MSL) and is in the 100-year flood plain of the both the Blue River and Indian Creek. However, a 500 year event floodwall protects the site.

- Approximately $46 \%$ of the site is covered by grass or gravel and is available for recharge. The site receives $\sim 34$ inches of precipitation per year.

- The topography of the complex is flat-lying except where it drops $~ 30$ feet along the Blue River and Indian Creek and where it rises $~ 50$ feet north of the KCP site.

- The Pennsylvanian bedrock (shales) in the vicinity of the KCP is noted for its uniformity. There are no structural features such as faults, that affect the KCP site. No fractures were observed in bedrock (shale) cores performed at the KCP site.

- The surface of the bedrock at the KCP site slopes to the east, reflecting surface topography. However, the slope or dip of individual layers (sandstones and shales) is to the west. Site lithologic logs indicate the presence of $\sim 1$ to 3 feet variation in the elevation of the bedrock surface.

- Groundwater flow at the KCP site is primarily to the east and discharges to the Blue River and Indian Creek. A portion of the KCP site groundwater flow is to the south.

Key Aquifer Properties

Aquifer parameters for the alluvial deposits at the KCP site have been estimated as:

Property

Porosity

Hydraulic Gradient

Horizontal Hydraulic Conductivity"

Groundwater Velocity

Storage Coefficient**

$\begin{array}{ccc}\text { Units } & \text { IankFarm } & \text { South Lagoon } \\ \% & 20 & 20 \\ \mathrm{ft} / \mathrm{ft} & 0.002 & 0.008\end{array}$

ftday

ft/yr

-
2.3

8.4

0.002
1.1

16

0.0005
Northeast Area

20

0.007 to 0.02

1.5

19 to 55

0.002

- Based on pumping test data. Conductivities calculated from bail and slug test data were $\sim$ one order of magnitude lower.

- Low values are reflective of the fine-grained nature of the aquifer materials.

The horizontal hydraulic conductivity of the shallow (knobtown) sandstone is 0.04 to $0.005 \mathrm{ft}$ day. The underlying shale is impermeable to water. 


\section{REMEDIATION SYSTEM}

\section{Overall Process Schematic}

\section{Extraction Well Network and Trench}

Replacement Treatment System

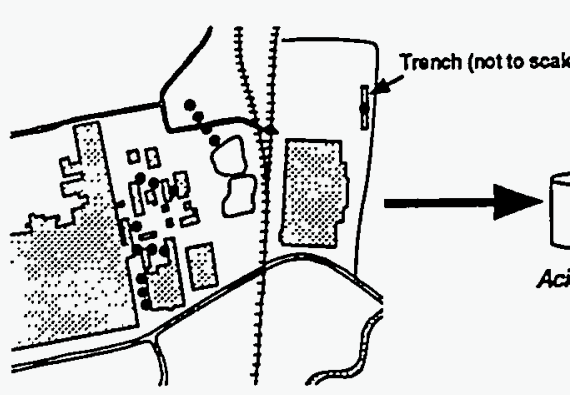

Acidification to solubilize inorganic metals, bag filtration, (UV/peroxide) oxidation of organic contaminants in one of two reactors, and subsequent neutralization.
Discharge to Sanitary Sewer
Fourteen extraction wells and one trench installed in three phases $(1987,1988$, and 1989).

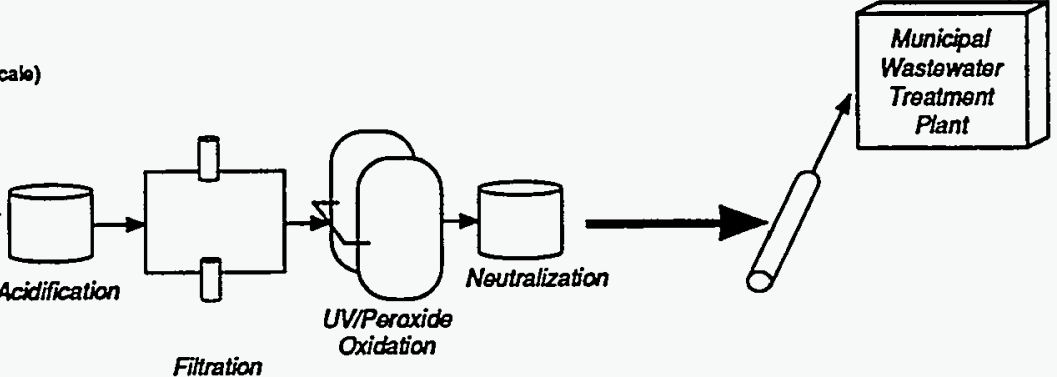

\section{Extraction Well Network}
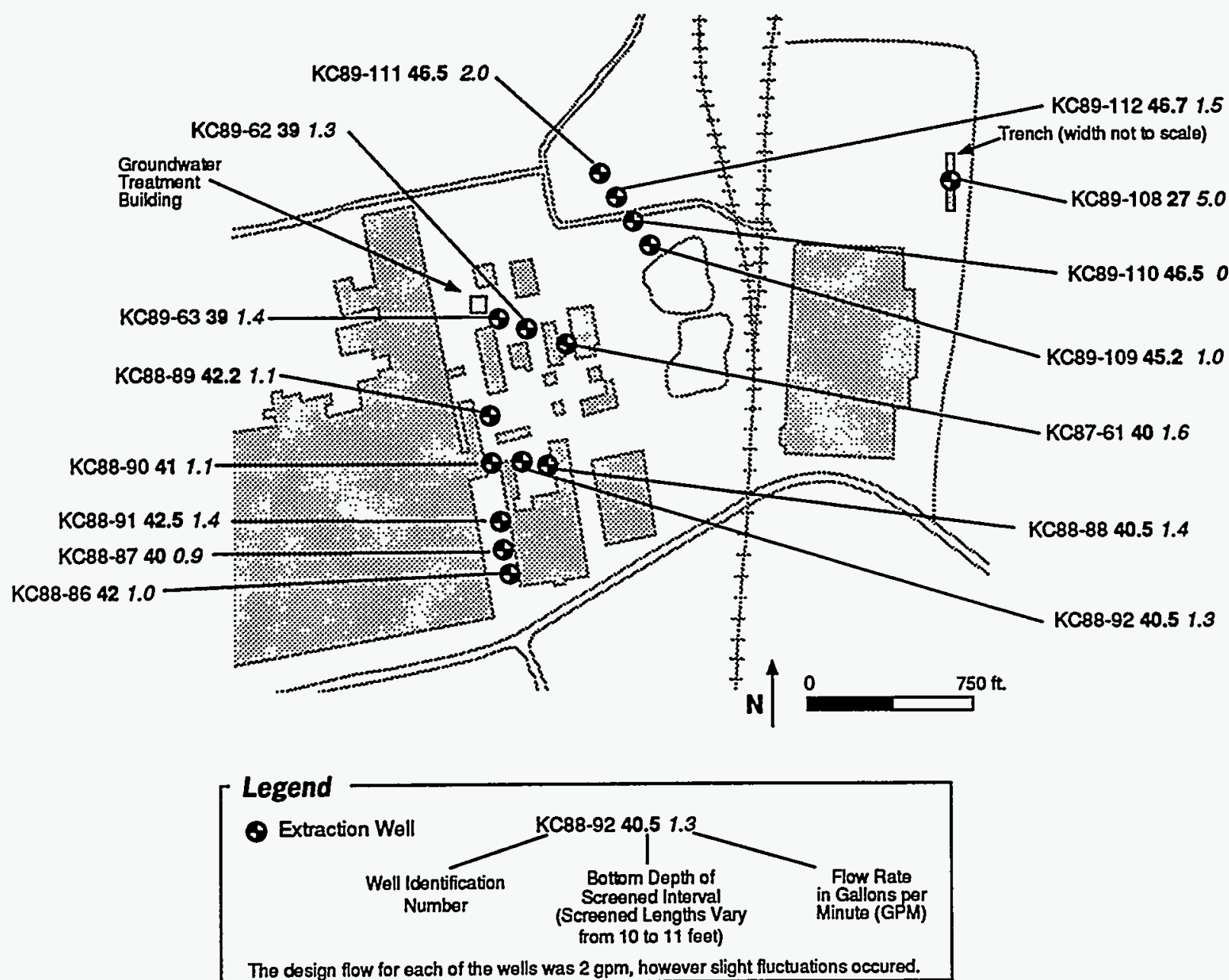
Extraction Well Detail

Typical extraction well (KCBg-112)

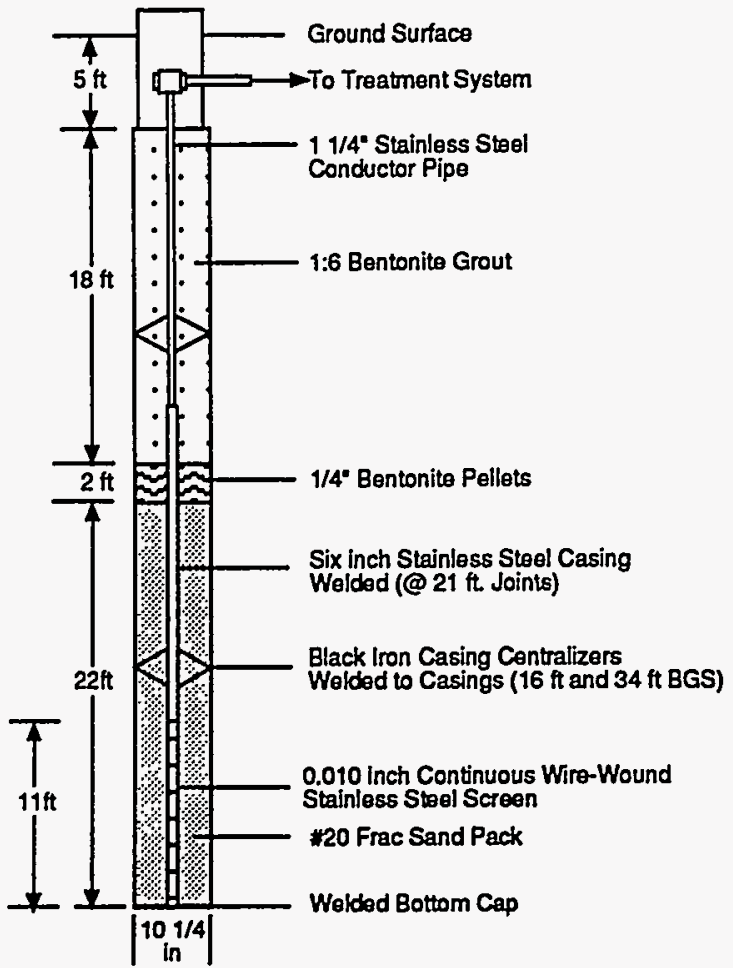

NOTES: 1.) Some extraction wells completed with subsurface vaults 2.) Submersible pumps with stainless stoel impellers in esch well
Interceptor Trench Schematic

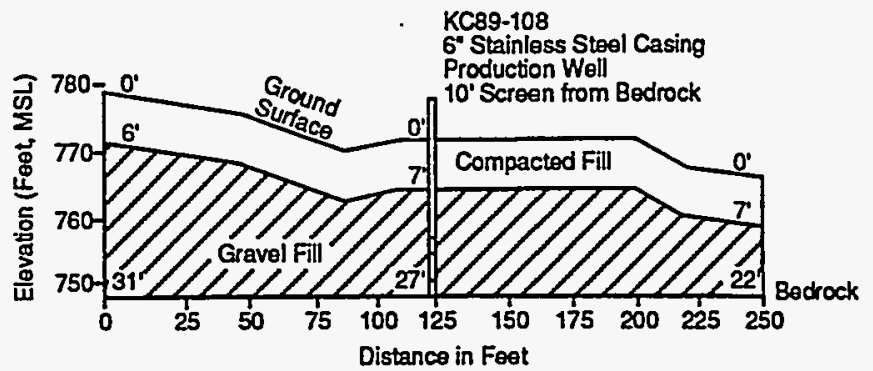

Key Design Criteria

- Hydraulic containment of VOC-contaminated groundwater

- Handle range of flow rates to allow for operational flexibility

- Destruction of organic contaminants in extracted groundwater rather than transfer to another media

- Redundant treatment capability to maintain hydraulic containment in the event of unanticipated breakdown, and to provide for treating increased flow rates during futurefinal site remediation

\section{Key Monitored Operating Parameters}

- Groundwater elevations

- Groundwater VOC concentrations

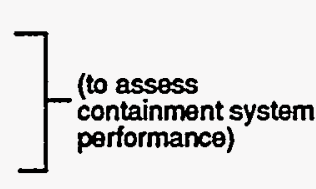

- Water flow rates

- Temperature, pressure, and pH

- UV and $\mathrm{H}_{2} \mathrm{O}_{2}$ dosage

- Filter pressures

- Influent/effluent contaminant concentrations (to assess treatment - systom operation and effectiveness

\section{Treatment System Schematic}

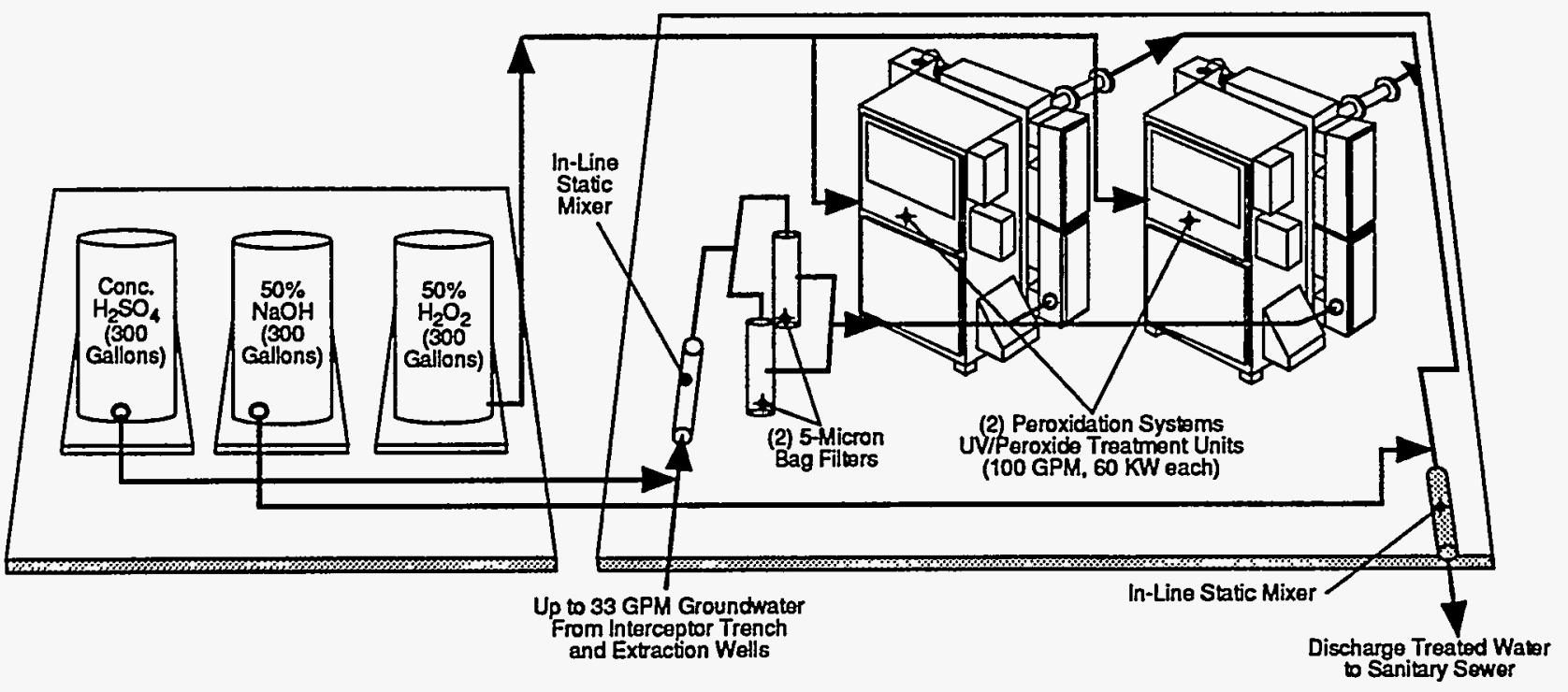




\section{PERFORMANCE}

\section{Performance Objectives}

- Prevent further migration of VOC-contaminated groundwater from 3 areas of identified contamination

- Design and operate treatment system to decrease VOC concentrations in extracted groundwater to below sewer discharge limits

\section{Remedial Action History/Plan}

Remediation at the KCP site is being implemented in a phased manner. The following groundwater-related interim remedial actions have been performed to date:

1988 Initiated pumping of groundwater (6 GPM) from Underground Tank Farm Area and treatment with $\mathrm{UV} / \mathrm{O}_{3} / \mathrm{H}_{2} \mathrm{O}_{2}$ system as interim measure and to demonstrate treatment technology

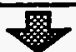

1990 Treatment of additional 14 GPM from TCE Still Area and 13 GPM from Northeast Area/001 Outfall using the same treatment system with additional Aqueous-Phase Granular Activated Carbon (GAC) polishing

1993/1994 Second-generation $\mathrm{UV} / \mathrm{H}_{2} \mathrm{O}_{2}$ treatment system installed to provide capacity for treating an additional 30 GPM (approximate) of groundwater from the 001 Outfall Area, and to provide additional operational and environmental benefits

\section{Overall Performance Summary}

Conclusions drawn after 5 (plus) years of operating the interim pump and treat system are summarized below:

- The extraction system appears to have been effective in substantially containing VOC-contaminated groundwater emanating from the KCP site. The KCP expects to begin extracting up to an additional $30 \mathrm{GPM}$ of VOC-contaminated groundwater to prevent its infiltration into the 001 Outfall storm sewer line during 1994.

- The concentrations of VOCs in groundwater and the extent of contamination has not changed considerably in the TCE Still Area, Underground Tank Farm Area or the Northeast Area/001 Outfall since initiating the Interim Remedial Action.

- While the initial AOP treatment system met discharge limits, ozone leaks, the need to treat air emissions and significant downtime required for maintenance contributed to the decision to change to the high-intensity $U V / H_{2} \mathrm{O}_{2} A O P$. The new AOP system has also operated within discharge limits.

\section{Operational Performance}

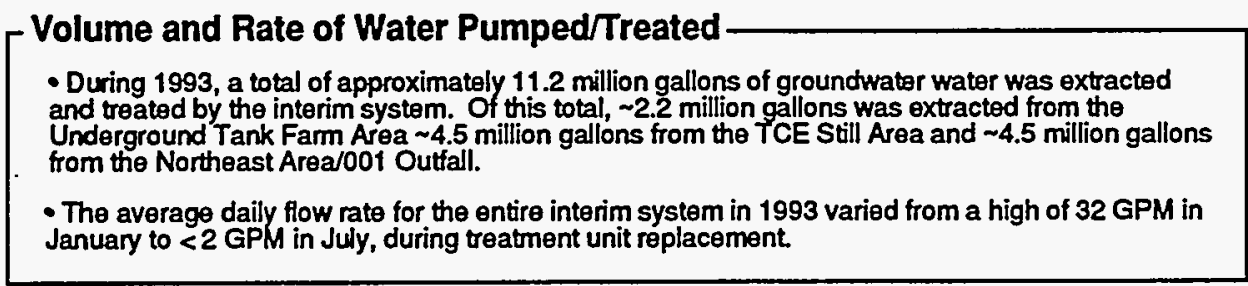

\section{System Downtlme}

- Numerous equipment malfunctions and a significant amount of downtime occurred during the first 15 months (May 1988 - July 1989) of continuous operation of th $U V / \mathrm{O}_{3} / \mathrm{H}_{2} \mathrm{O}_{2}$ system. The system operated $>65 \%$ of the time in 1988 except during September when it was shut down for equipment modifications. The interim system operated $61 \%$ of the time in 1989 except during June when it was down for servicing modifications by the manufacturer. Except during downtime periods for construction, equipment, modifications and frozen pipes, and the UV/O $\mathrm{O}_{3} \mathrm{H}_{2} \mathrm{O}_{2}$ system operated $>90 \%$ of the time from 1990 until May 1993 when it was replaced by the high intensity $\mathrm{UV} / \mathrm{H}_{2} \mathrm{O}_{2}$ system.

- The replacement $\mathrm{UV} / \mathrm{H}_{2} \mathrm{O}_{2}$ system commenced continuous operation in August/September 1993. This treatment system has operated $>95 \%$ of the time. Much of the maintenance that required the prior treatment system to be shut down can now be performed while the replacement system remains operational. 


\section{Hydrodynamic Performance}

- A modeling evaluation performed in May 1992 concluded that the extraction system was substantially containing the three primary groundwater VOC plumes at the KCP site. The planned addition of supplemental extraction wells near Outfall 001 is intended to decrease infiltration of contaminated groundwater into storm sewer lines to comply with NPDES permit effluent standards.

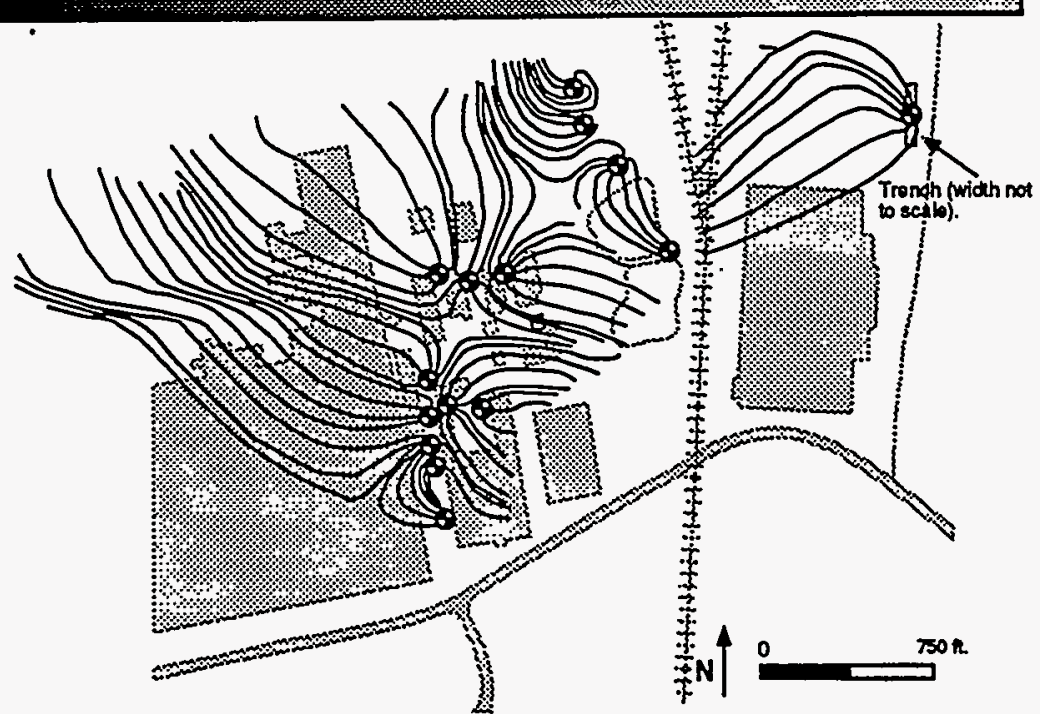

\section{Effect on In Situ Contaminant Concentrations}

While the pump and treat system has removed a substantial mass of VOCs from the subsurface, statistically significant changes of in situ grounowater VOC concentrations have not occurred.

\section{Treatment System Performance}

- The original $\mathrm{UV} / \mathrm{O}_{3} / \mathrm{H}_{2} \mathrm{O}_{2}$ treatment system was replaced with the high intensity $\mathrm{UV} / \mathrm{H}_{2} \mathrm{O}_{2}$ in May 1993 to provide capacity to treat an additional 30 GPM from the 001 Outfall Area. Despite the on-going maintenance problems, the $\mathrm{UV} / \mathrm{O}_{3} / \mathrm{H}_{2} \mathrm{O}_{2}$ treatment system routinely met permit discharge limits at a flow rate $\sim 6$ GPM from 1988 until 1990. The sewer discharge limit for total organic halogens was exceeded on 2 occasions in 1990 as a result of the adding of $\sim 27$ GPM of groundwater extracted from the TCE Still Area and the Outfall 001/Northeast Area. The original system was designed to handle only 25 GPM of water containing VOCs at concentrations higher than predicted by an interim Corrective Measure Study. Aqueous-phase granular activated carbon (GAC) polishing of the $U V / \mathrm{O}_{3} / \mathrm{H}_{2} \mathrm{O} U$ init effluent was added in the late 1990 to remove residual organics prior to discharge. An in-line filter was installed and backwashing instituted to extend the life of the GAC by removing iron and manganese that precipitated following oxidation in the AOP reactor.

- Following successful completion of a rigorous acceptance testing program of the replacement $U V / \mathrm{H}_{2} \mathrm{O}_{2}$ system during late 1992, the system was placed into operation during May 1993. As illustrated in the following graph, total VOC concentrations in the replacement system effluent have been well below the sewer discharge limit. The on-going maintenance problems experienced with the initial system have been eliminated.

\section{UV/Peroxide Treatment System Performance}

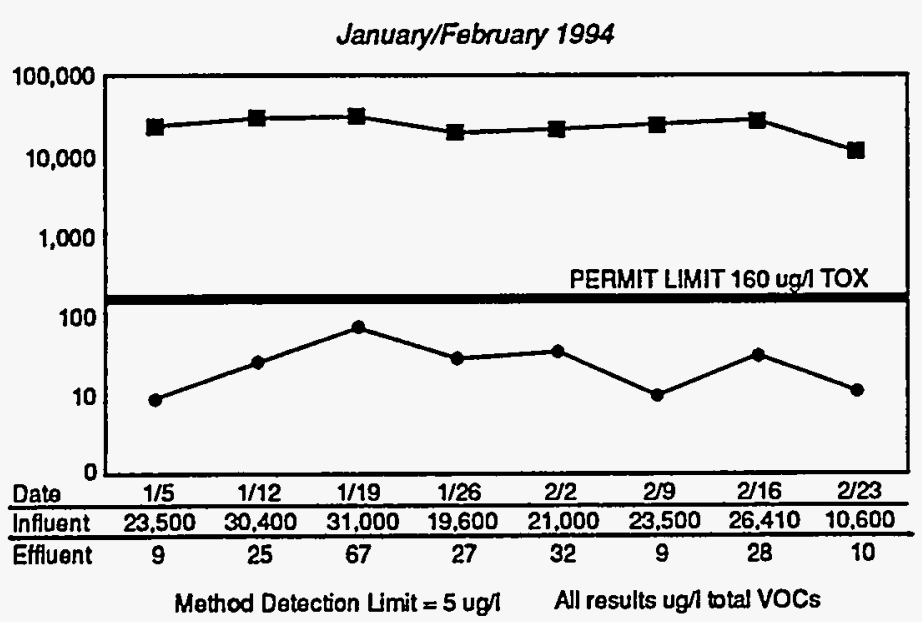

- The initial UV/O $\mathrm{O}_{3} / \mathrm{H}_{2} \mathrm{O}_{2}$ system destroyed $94.6 \%$ VOCs; $-3.7 \%$ were emitted to ambient air and $\sim 1.7 \%$ were discharged to the sanitary sewer system. The replacement $\mathrm{UV} / \mathrm{H}_{2} \mathrm{O}_{2}$ system destroyed $>99.95 \%$ VOCs; $\sim<0.05 \%$ are discharged to the sanitary sewer system and there are no emissions.

- The system is designed to treat up to 30,000 ug/. Influent averaged approximately 25,000 ugll.

- Up to 0.3 ug/ PCBs have been detected in the UV/ $\mathrm{H}_{2} \mathrm{O}_{2}$ treatment system influent. PCBs have not been detected in the treated groundwater discharged to the sanitary sewer. 
- Although advanced oxidation was more expensive then other alternatives such as air stripping/GAC, it was selected because of its waste minimization benefits. With advanced oxidation the contaminants are destroyed, and not transferred to another media.

- The selection of the high intensity $\mathrm{UV} / \mathrm{H}_{2} \mathrm{O}_{2}$ treatment to replace the $\mathrm{UV} / \mathrm{H}_{2} \mathrm{O}_{2}$ was due in part to cost savings associated with: eliminating GAC polishing, eliminating the need to treat air emissions, and reduced operation and maintenance labor and expenses.

- Capital and operating costs for the replacement $U V / \mathrm{H}_{2} \mathrm{O}_{2}$ system is presented below. Operating costs for treatment (including replacement parts, laboratory analysis, utilities, labor, and raw materials) calculated by Oak Ridge National Laboratory were $\$ 15.51 / 1,000$ gallons for the first-generation $\mathrm{UV} / \mathrm{O}_{3} / \mathrm{H}_{2} \mathrm{O}_{2}$ demonstration unit and are projected to be $\$ 13.80 / 1,000$ gallons for the second-generation UV/ $\mathrm{H}_{2} \mathrm{O}_{2}$ replacement units once the additional 001 Outfall extraction system commences operation. The costs presented below are based on actual costs spent from fiscal years 1987 to 1994; the cost figures are not in constant dollars.

\section{Capital Costs}

Extraction Wells, Vaults, Pumps, Piping, Trenching, Electrical Conduit, \& Utilities

$\$ 1,213,900$

Bag Filter Units (2)

Tanks (3)

Treatment Buildings (site preparation, construction, and engineering), 3 original extraction wells

Control Systems

126,000

2,300

Equipment Installation

20,000

Startup (including acceptance testing)

15,000

Total Capital Cost

$\$ 1,383,400$

\section{Operating Costs}

Electrical Power

$\$ 25,300$

Maintenance

Labor

52,200

Equipment Repair and Replacements ${ }^{a}$

3,300

Engineering Support and Project Management

44,200

Laboratory Analysis (Influent/Effluent)

78,000

Monitoring Well Analysis

110,000

Consumables

Hydrogen Peroxide 3,600 gallons/year @ \$4.00/gallon

14,400

Sulfuric Acid 3,600 gallons/year @ \$1.09/gallon

3,900

Caustic 7,200 gallons/year @ \$1.91/gallon

13,800

Bag Filters

700

Extraction Pump and Motor Assembly Replacement (2/year)

1,200

Transport and Disposal of Spent Filters and Personal Protective Equipment

500

Extraction Well Rehabilitations

Chemical Treatment

5,300

Redevelopment

2,400

Total Annual Operating Cost

a Average annual cost of equipment repair and replacoment costs from 1983 to 1994, including costs associated with system start-up and the purchase of spare parts. 
REGULATORY/INSTITUTIONAL ISSUES

- The KCP Site investigation is being performed in accordance with a U.S. Environmental Protection Agency RCRA 3008 (h) Administrative Consent Order in 1989. Initial investigation efforts, and the extraction and treatment of groundwater from the Underground Tank Farm Area were performed as voluntary actions in 1988 with EPA cognizance.

- Treatment of extracted groundwater using $\mathrm{UV} / \mathrm{O}_{3} / \mathrm{H}_{2} \mathrm{O}_{2}$ was initiated in 1988 as a demonstration of one of the first fullscale operating AOP systems. A rigorous program of pilot testing and long term performance monitoring was implemented to assure regulators of the effectiveness of this treatment technique and to develop data on long-term reliability and operation and maintenance costs. The second generation $\mathrm{UV} / \mathrm{H}_{2} \mathrm{O}_{2}$ that replace the $\mathrm{UV} / \mathrm{O}_{3} / \mathrm{H}_{2} \mathrm{O}_{2}$ system in 1992 also underwent rigorous prove-in testing in accordance with a Startup Plan approved by EPA and the City of Kansas City, MO.

- Treated water is discharged to the municipal sanitary sewer system under the provisions of a wastewater discharge permit issued by the Kansas City Water and Pollution Control Department in February 1988. Discharge limits are summarized below:

$\begin{array}{lclc}\text { Parameter } & \text { Concentration (ma/L) } & \text { Parameter } & \text { Concentration(mo/L) } \\ \text { Cadmium } & 0.69 & \text { Arsenic } & 0.250 \\ \text { Chromium } & 2.77 & \text { Total Organic Halogen } & 0.16 \\ \text { Copper } & 3.38 & \text { Sulfides } & 10.0 \\ \text { Load } & 0.69 & \text { Oil and Grease } & 100 \\ \text { Nickel } & 3.98 & \text { Total Cyanide } & 2.0 \\ \text { Zinc } & 2.61 & & \\ \text { Iron } & 100.00 & & \\ \text { Manganese } & 20.00 & & \\ \text { Boron } & 1.00 & & \end{array}$

- Final cleanup goals have not yet been established for the site. Cleanup goals will be set subsequent to completing RFVCMS activities.

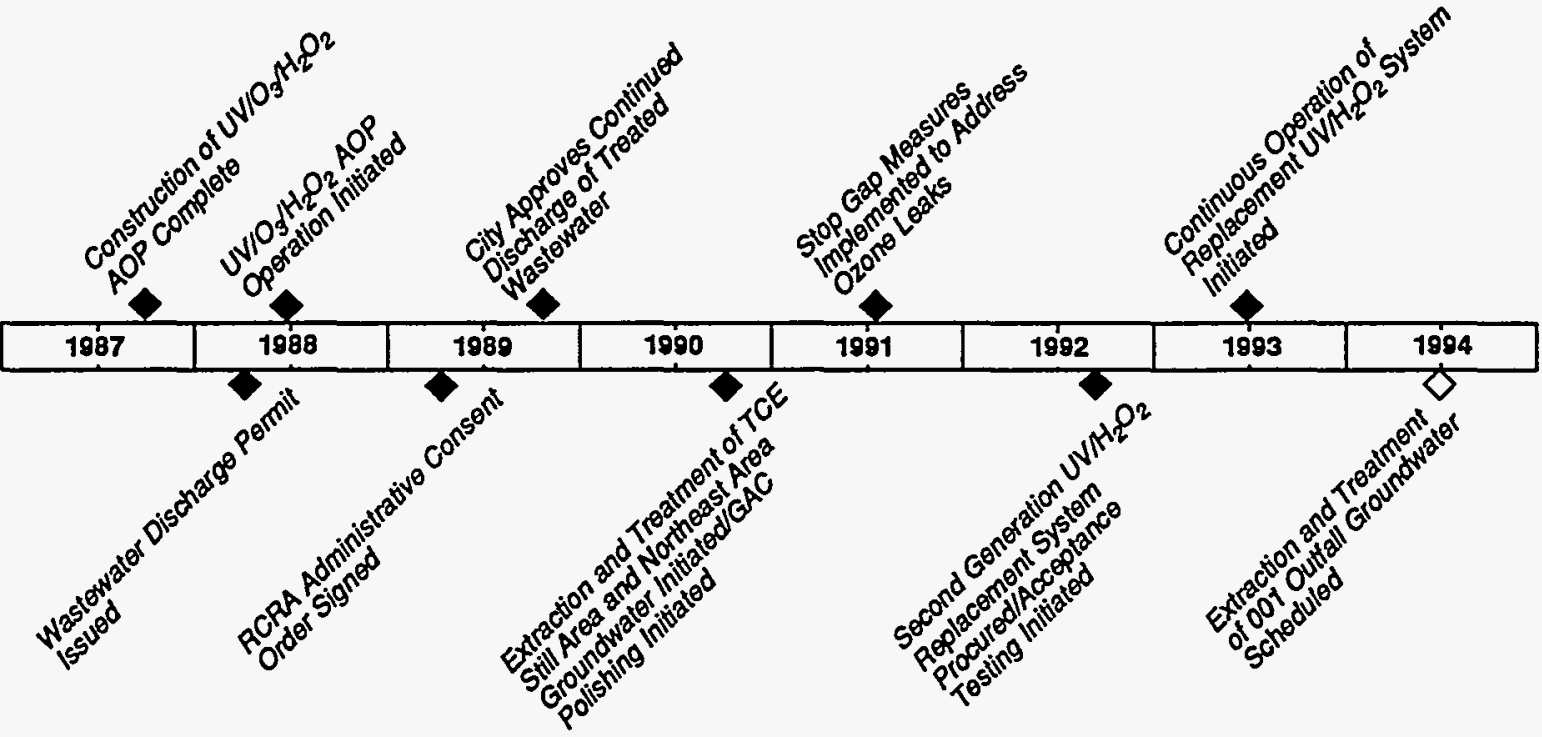

- Extraction and treatment of groundwater from near the 001 Outfall will be initiated following NEPA review and obtaining approval from a railroad to a pipe groundwater beneath an active rail line that crosses the KCP site. 


\section{Implementation Considerations}

- An understanding of the extent of contamination at this site has evolved over a decade of investigation, monitoring, and remediation. Defining the extent of contamination has focused on determining the need for remediation in specific areas of the site, selecting and designing remedies, and evaluating the effectiveness of implemented remedial actions.

- Monitoring data and modeling results suggest that predicting the rate of aquifer restoration my be complicated due to hydrogeologic variability caused by leaking underground utilities, building footing tile drains and other anthropogenic factors and the likely presence of DNAPL(s) in a number of areas of the site.

- Initiating an interim remedial action provided for hydraulic containment of VOCs dissolved in groundwater while the full extent of contamination and supplemental remedial actions are defined.

- Extraction flow rates must be manually adjusted at the individual well heads. The ability to control flows from the central treatment system building would eliminate difficulty in performing this task.

- Substantial and frequent fouling of the extraction system wells with bacterial slime and oxides of naturally-occurring iron and manganese have resulted in the need for frequent chemical treatment and redevelopment of wells, and repair/replacement pumps, pump motors and water level probes.

- Vaults and pipe conduits allow oxygenated rainwater to drain into extraction wells through vent tubes, contributing to the growth of bacterial slime and need for more frequent well treatment/redevelopment. Modifications made to minimize this concern have included installation of berms and drainage systems around selected well vaults. Measures to epoxy seal openings in the piping conduit are being investigated.

- The initial UV/O $/ \mathrm{O}_{3} / \mathrm{H}_{2} \mathrm{O}_{2}$ treatment system was not designed to adequately handle the flow rate and VOC concentrations realized with the interim containment system. The replacement $U \mathrm{UV}_{2} \mathrm{O}_{2}$ treatment system was designed to handle a wider range of flow rates and concentrations to provide operational flexibility.

- The initial UV/O $\mathrm{O}_{3} / \mathrm{H}_{2} \mathrm{O}_{2}$ treatment system experienced significant downtime for acid cleaning of filters, ozone sparger tubes and UV lamp sheathes, and GAC backwashing/changeout. The replacement system provides for $\mathrm{pH}$ adjustment prior to $\mathrm{UV} / \mathrm{H}_{2} \mathrm{O}_{2}$ treatment to minimize fouling caused in part by oxidation of inorganics.

\section{Technology Limitations}

- The initial UV/O $/ \mathrm{H}_{2} \mathrm{O}_{2}$ treatment system was a first-generation AOP technology installed and operated at the KCP for demonstration purposes. The second-generation (replacement) AOP treatment system, operational since May 1993, has performed well at a lower cost and without the on-going maintenance problems experienced with the initial demonstration system.

- The saturated hydrocarbons present at the KCP site were readily treated by both the initial $U V / \mathrm{O}_{3} / \mathrm{H}_{2} \mathrm{O}_{2}$ and the secondgeneration/replacement $\mathrm{UV} / \mathrm{H}_{2} \mathrm{O}_{2}$ systems. AOP manufacturers' literature indicates that treatment efficiencies for unsaturated hydrocarbons are much lower.

- $\mathrm{UV} / \mathrm{H}_{2} \mathrm{O}_{2}$ was selected instead of a second-generation $\mathrm{UV} / \mathrm{O}_{3} / \mathrm{H}_{2} \mathrm{O}_{2}$ AOP to replace the initial treatment system because systems that employ ozone: require more maintenance (e.g., the ozone generator and delivery system), residual ozone in the headspace of the reaction chamber is corrosive to the chamber, and catalytic oxidation is required to destroy ozone in the air discharge.

\section{Future Technology Selection Considerations}

- Greater attention should be paid to the design of extraction well systems that minimize operation and maintenance problems.

- AOP systems can destroy saturated hydrocarbons in extracted groundwater. However, designs must consider the potential for fouling with oxidized inorganics and the implementation of pretreatment measures when appropriate to ensure satisfactory performance and manageable maintenance. 
This analysis was prepared by:

Stone \& Webster Environmental

Technology \& Services

245 Summer Street

Boston, MA 02210

Contact: Bruno Brodfeld (617) 589-2767

Assistance was provided by the

ALUEDSIGNAL INC.

which supplied key information and reviewed report drafts.

for:

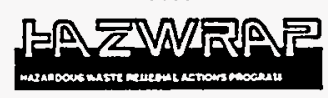

HAZARDOUS WASTE REMEDIAL ACTIONS PROGRAM

Environmental Restoration and Waste Management Programs

Oak Ridge, Tennessee 37831-7606

managed by

MARTIN MARIETTA ENERGY SYSTEMS

for the

U.S. Department of Energy

under Contract DE-AC05-84OR-21400

This analysis was funded by:

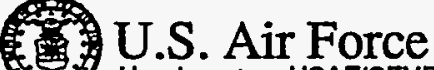

Headquarters USAFICEVR

This analysis accurately reflects the performance and costs of the remediation:

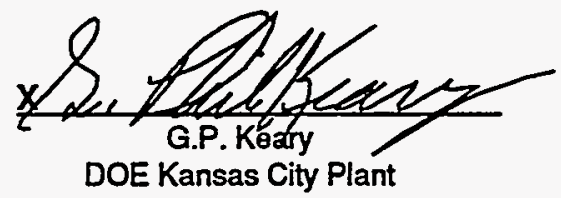

Environmental Restoration Program Manager 


\section{SOURCES}

\section{Major Sources For Each Section}

Site Characteristlcs:

Remedlation System:

Performance:

Cost:

Regulatory/netitutional lesues:

Schodule:

Lessons Learned:
Source \#s (from list below) 3, 4, 6, 7, 8, 9, and 10

Source \#s 1, 2, 3, 4, 5, 7, 8, 9, and 10

Source \#s 1, 2, 3, 4, 6, 7, 8, 9, 10, and 11

Source \#s 1, 2, 8, and 11

Source \#s 1, 3, 4, 5, 6, 9, and 11

Source \#s 1, 2, 4, 5, 6, 7, and 10

Source \#s 1, 2, 4, 6, 7, 10, and 11

\section{Chronological List of Sources and Additional References}

1. Kansas City Plant Groundwater Treatment System Overview, prepared by AlliedSignal, Inc., Undated.

2. Kansas City Plant Ultraviolet/Ozone/Hydrogen Peroxide Groundwater Treatment System Ovenview, prepared by M.E. Stites, Environment, Safety and Health Department AlliedSignal, Inc., and R.F. Hughes, Energy and Environmental Systems Division, Oak Ridge Associated Universities, Undated.

3. Tank Farm Interceptor System Evaluation and Treatment Unit Corrective Action Plan - Rev 1, April 1991.

4. Groundwater Interceptor System Evaluation, Kansas City Plant, prepared by Department of Energy, Albuquerque Operations Office, Environmental and Health Division, Environmental Programs Branch, May 1992.

5. Groundwater Treatment System Interim Measures Plan, U.S. DOE Kansas City Plant, revised August 1993.

6. TCE Still Area ACRA Facility Investigation Report - Draft, Kansas City Plant, prepared by Department of Energy, Albuquerque Operations Office, Environmental and Health Division, Environmental Programs Branch, Environmental Restoration Program, September 1993.

7. Kansas City Plant Groundwater Remediation, prepared by AlliedSignal, Inc., October 15, 1993.

8. Northeast Area/001 Outfall Corrective Measure Study - Draft, Kansas City Plant, prepared by Department of Energy, January 1994.

9. Annual Groundwater Monitoring Report for Calender Year 1993, Kansas City Plant, prepared by Department of Energy, Albuquerque Operations Office, Environmental Programs Branch, Environmental Restoration Program, March 1994.

10. Data Package Supplied by Mr. Michael E. Stites, AlliedSignal, Inc., April 25, 1994.

11. Personal Communications with Michael E. Stites and Joseph L. Baker, AlliedSignal, Inc. May and June 1994. 


\section{TECHNOLOGY APPLICATION ANALYSIS}

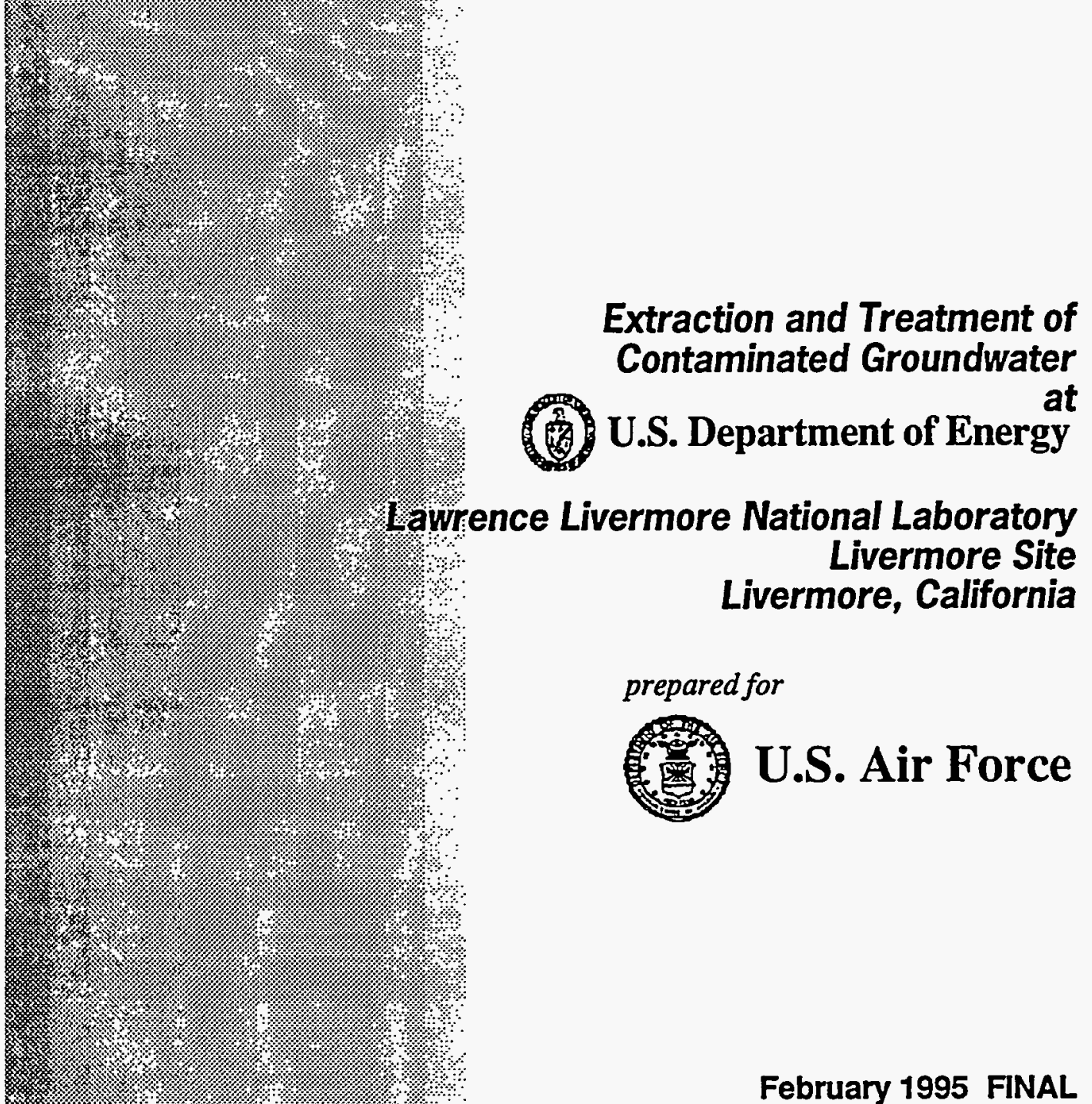


SITE

Lawrence Livermore National Laboratory (LLNL) Livermore Site Livermore, California
1. TECHNOLOGY APPLICATION

This analysis reports the use of optimized hydraulic control, source removal and advanced technologies to clean up groundwater contaminated with volatile organic compounds (VOCs), fuel hydrocarbons (FHCs) and chromium by a network of treatment facilities employing ultraviolet (UV)/oxidation, air stripping, ion exchange and granular activated carbon (GAC) technologies. Initial treatment began in 1989 and additional capacity is being phased in through an ongoing evaluation process. Vadose zone remediation efforts are not addressed in this analysis.

\section{SITE CHARACTERISTICS}

\section{Site History/Release Characteristics}

- The 800-acre LLNL site was converted from agricultural use into a flight training base and aircraft assembly and repair facility by the Navy in 1942. In 1951, the Atomic Energy Commission converted the site into a weapons design and basic physics research laboratory. Later site missions have included programs in biomedicine, energy, lasers, magnetic fusion energy, and environmental science.

- Initial releases of hazardous materials occurred in the mid to late 1940s. There is also evidence that subsequent localized spills, leaking tanks and impoundments, process cooling water and landfills released VOCs, FHCs, chromium and tritium to sediments and groundwater, primarily from 14 major areas of concern.

- In 1983, VOCs were detected by LLNL in a domestic water supply well west of the site. A regulatory order to investigate groundwater quality was issued by the state in 1984 and ultimately lead to investigation of over 350 potential release sites.

- Bottled drinking water was supplied to nearby residents beginning in 1983 and all affected supply wells were permanently sealed between 1985 and 1989 by LLNL. Selected waste pits and a landfill were excavated and backfilled in 1982/83 and 1984, respectively. The LLNL site was added to the National Priorities List in 1987.

\section{Contaminants of Concern}

\section{Vocs:}

Trichloroethylene

Perchloroethylene

1,1 \& 1,2-Dichoroethylene

1,1 \& 1,2-Dichloroethane

Carbon tetrachloride

1,1,1-Trichloroethane

Chloroform

FHCs:

Benzene

Toluene

Ethylbenzene

Xylenes

Ethylene dibromide

Metals:

Chromium

Trivalent chromium

Hexavalent Chromium

Radiological Parmotor

Tritium

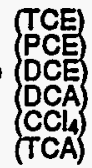

\section{(8)}

to

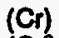

$\left(\mathrm{Cr}^{3+}\right)$

(Cr6t)

$\left({ }^{3} \mathrm{H}\right)$

\section{Contaminant Properties}

\begin{tabular}{|c|c|c|c|c|c|c|}
\hline Properties" & TCE & PCE & $1,1-D C E$ & Chloroform & $\mathrm{CCl}_{4}$ & Benzeno \\
\hline Density $\left(g / \mathrm{cm}^{3}\right)$ & 1.47 & 1.63 & 1.22 & 1.50 & 1.58 & 0.87 \\
\hline $\begin{array}{l}\text { Vapor Pressure } \\
(\mathrm{mm} \mathrm{Hg})\end{array}$ & 57.9 & 17.8 & 600 & 151 & 90.0 & 95.2 \\
\hline $\begin{array}{l}\text { Henry's Law Constant } \\
\left.\text { (atm- } \mathrm{m}^{3} / \mathrm{mole}\right)\end{array}$ & 0.0091 & 0.0259 & 0.0340 & 0.0029 & 0.0241 & 0.0056 \\
\hline Wator Solubility (mg/) & 1,100 & 150 & 2,250 & 8,200 & 757 & 1.750 \\
\hline $\begin{array}{l}\text { Octanol -Water } \\
\text { Partition } \\
\text { Coefficient; }\left(K_{O_{W}}\right)\end{array}$ & 240 & 398 & 69.2 & 93.3 & 437 & 132 \\
\hline $\begin{array}{l}\text { Organic Carton } \\
\text { Partition } \\
\text { Coefficient (Koc) }\end{array}$ & 126 & 364 & 65.0 & 47.0 & 439 & $\begin{array}{l}83.0 \\
{ }^{\circ} \mathrm{C}, 1 \mathrm{~atm}\end{array}$ \\
\hline
\end{tabular}

\section{Site Conditions}

- The ground surface slopes gently to the northwest changing in elevation from $670 \mathrm{ft}$ above mean sea level (MSL) to 570 $\mathrm{ft}$ above MSL from the southeast to northwest corners. Two intermittent streams, the Arroyo Seco and the Arroyo Las Positas, traverse the area.

- Climate is semiarid with annual precipitation around 14 inches/year.

- Land north and south of the site is zoned for industrial use, high-density urban areas are west of the site, and east of the site is primarily agricultural land.

- Municipal water supply wells in downtown Livermore approximately 1.6 miles away from the contaminant plume are the primary drinking water source for over 10,000 of Livermore's 50,000 plus residents. 


\section{Nature and Extent of Contamination}

Data below taken from Roforence 9 excopt where noted.

VOCs: - VOCs underlie approximately $85 \%$ of the LLNL site over an area of about 1.4 square miles. The VOC plume thickness varies between 30 and $100 \mathrm{ft}$ and rarely exceeds $200 \mathrm{ft}$ in depth.

- TCE and PCE are the predominant VOCs with maximum concentrations of 4800 and 1100 parts per million (ppm) respectively. TCE, PCE and chloroform account for $91 \%$ of the total quantity of dissolved VOCs. VOCs exceed 1000 parts per billion (ppb) in groundwater at only 10 of $\mathbf{3 0 0}$ monitoring wells.

- The vadose zone generally contains low residual VOC concentrations (less than $100 \mathrm{ppb}$ ) except near a pair of release sources in the southeastern part of the site where up to $6000 \mathrm{ppb}$ have been found.

FHCs: - FHCs ranging in concentration from about 1 to $16,000 \mathrm{ppb}$ in groundwater are almost exclusively found near the site of a previous gasoline leak. Horizontal migration has been limited to about $500 \mathrm{ft}$ due to low groundwater velocities. Significant vadose zone contamination in the area, up to $11,000,000 \mathrm{ppb} F \mathrm{FCs}$ have been detected in the vadose zone. Demonstration of Dynamic Underground Stripping has removed an estimated 10,000 gallons of FHCs from November 1992 to January 1994 (References 1 and 4).

Motals: - Metals from both natural conditions and facility activities have exceeded drinking water standards in sparse locations. Chromium, naturally occurring or perhaps from use as a corrosion inhibitor in cooling towers, is found in concentrations up to $160 \mathrm{ppb}$ in groundwater. No consistent plume or migration pathways have been identified for metal contaminants.

Radlological - Groundwater in the few wells where tritium is of concern would be expected to decay below federal and Parameters: state drinking water standards before the water migrates ofisite if no remediation was conducted.

\section{Contaminant Locations and Hydrogeologic Profiles}

Remedial investigation activities at LLNL involved reviow of over 350 potential release sites which were uttimately incorporated within 14 areas of concern. The source investigation methodology involved review of historical information, sample collection and drilling of over 800 subsurface borings. The site hydrogeology was characterized from:

- field boring logs

- borehole geophysical logs - hydraulic test data (over 300 tests were conducted over a 4 year investigation period) - sediment and water chemistry - subsurface data from other investigations, including seismic and soil vapor surveys

\section{Site Lavout (Plan View)}

Shadod areas incicato identified source areas of contamination.

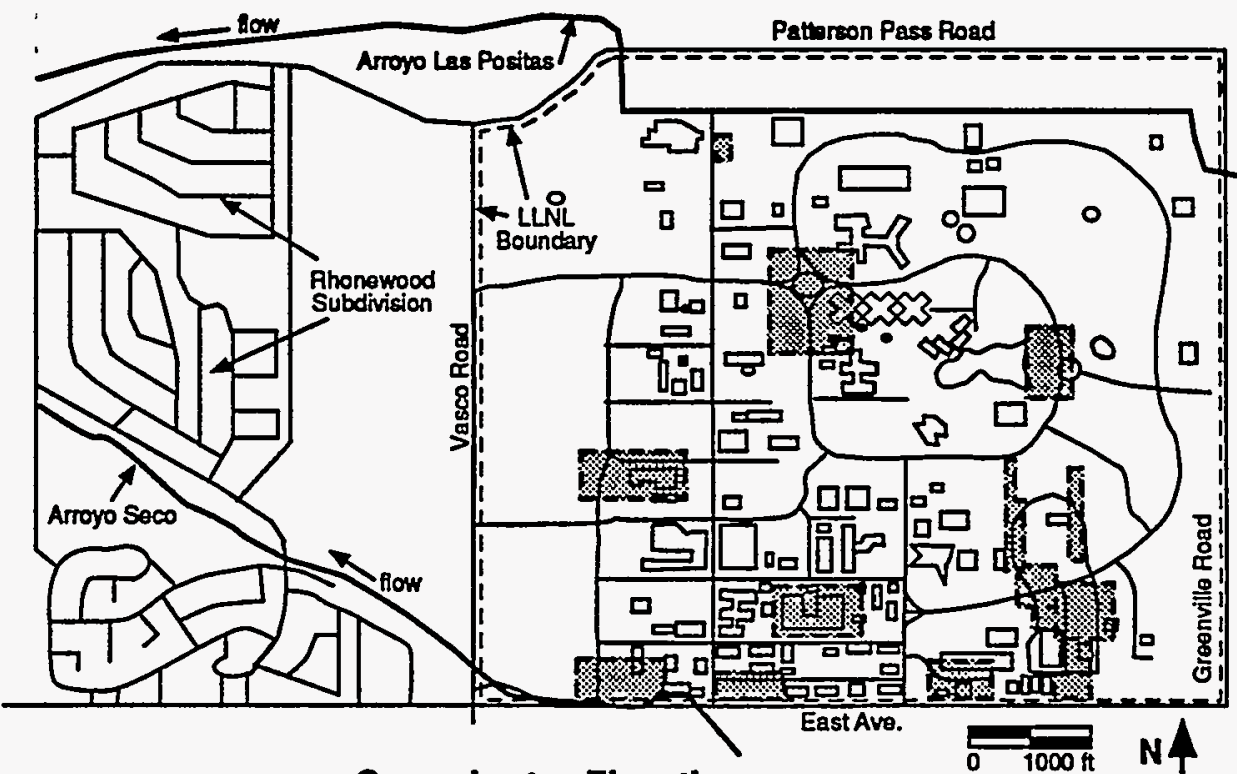

Groundwater Elevations

All elevations in ft above MSL (March 1989).
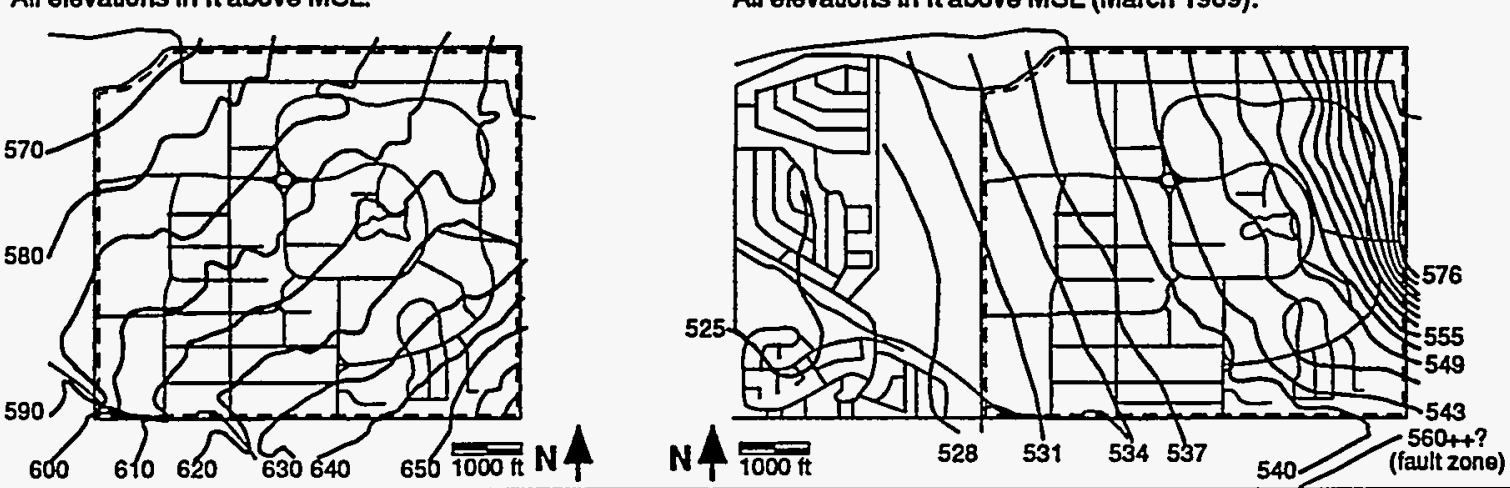


\section{Contaminant Locations and Hydrogeologic Profiles (Continued)}

Distribution of VOCs in Groundwater

Isoconcentration contour map of total VOCs

in groundwater integrated over 0-100 ft depth

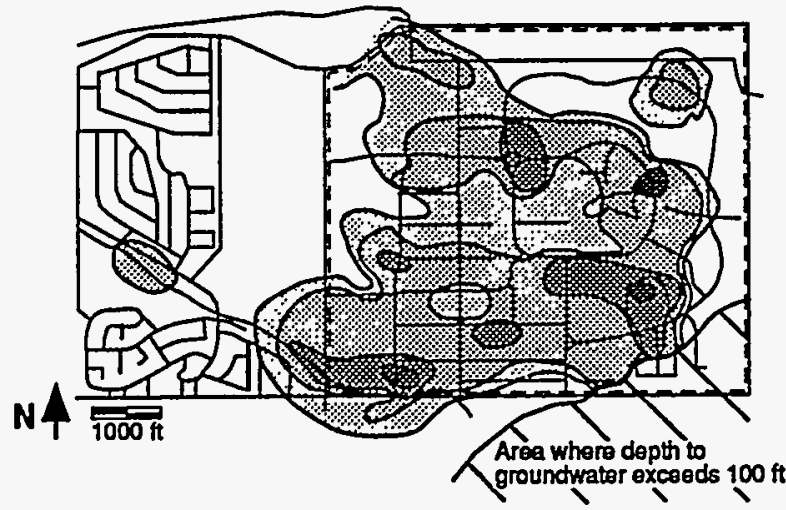

Haxdmum Pro-Remedlation Concentrattons for Selocted VOCs

All data are expressed in ppb and were obtained betwoen 3/20 and 3/91

\begin{tabular}{cccccccccc} 
TCE & PCE & 1,1-DCE & Chloroform & CC $_{4}$ & B & T & E & X & Total voCs \\
\hline 4800 & 1050 & 370 & 270 & 91 & 4600 & 4200 & 610 & 3700 & 5808
\end{tabular}
Isoconcentration contour map of total VOCs in groundwater integrated over 100-200 ft depth

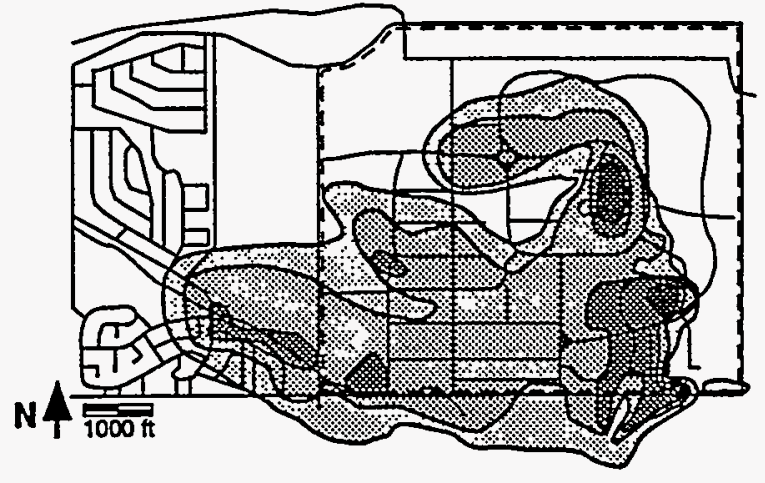

Legend

All concontrations

in ppb

1 to $10 \mathrm{ppb}$

10 to $100 \mathrm{ppb}$

100 to $1,000 \mathrm{ppb}$

$>1,000 \mathrm{ppb}$

\section{Cross-Section Indicating Areas of VOC Contamination}

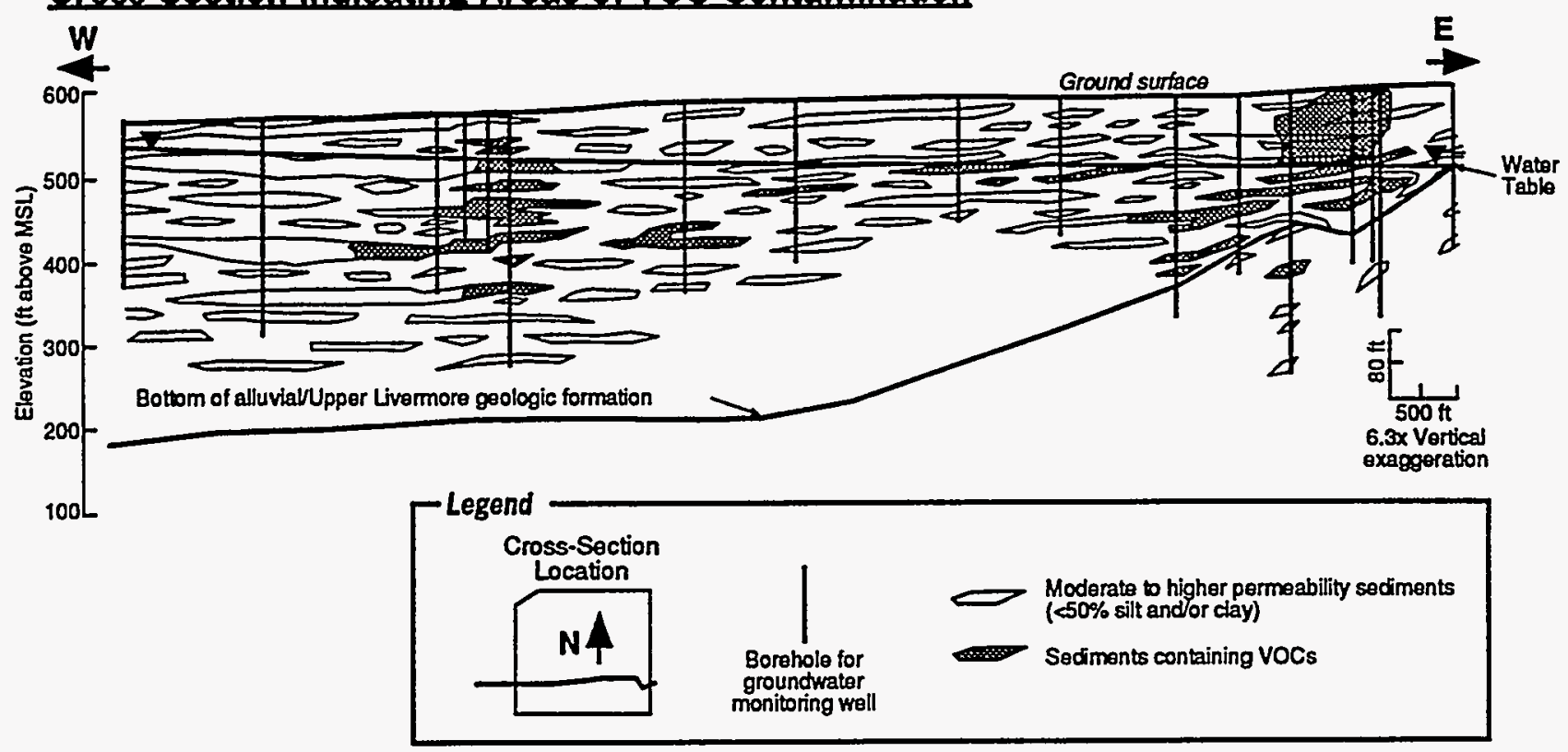




\section{Site Characterization Methodology}

Initial remedial investigation efforts at LLNL using a depth-sampling technique led to an understanding of subsurface conditions and contaminant locations. Geologic cross-sections (see page 3 ) showing locations of contaminants were constructed using these data. More recent site characterization activities have focused upon the development of a comprehensive hydrostratigraphic characterization of the site through application of a systematic methodology. This methology entails:

\section{Evaluating Independent Data Sets}

- hydraulic test results \& water levels

- geophysical well logs

- geologic core descriptions

- chemical analyses of soil \& groundwater

- high resolution seismic reflection

Defining Hydrostratigraphy

3) Generating Information Displays

- hydrostratigraphic cross-sections

- hydraulic communication maps

- structure surface maps

- isopach maps

- potentiometric surface maps

- isoconcentration maps

4 Development of a Conceptual Model for 3-D

Overall, 4 lithologic units (not shown below) and 7 hydrostratigraphic units (shown below) have been identified.

This methodology provides information for optimizing the location of extraction wells to:

- maximize mass removal rates, and

- hydraulically control plumes.

Fate and Transport SImulations

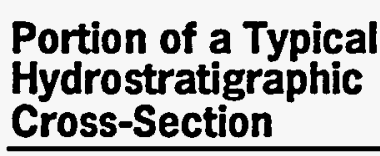




\section{Key Soil/Aquifer Characteristics}

- The site is underlain by several hundred feet of complexly interbedded alluvial and lacustrine sediments. A shallow groundwater system of predominantly heterogeneous alluvial deposits and a deeper groundwater system of fluvial and lacustrine sediments are separated by a regional confining aquitard.

- Depth to groundwater varies from about $120 \mathrm{ft}$ in the southeast corner to about $25 \mathrm{ft}$ in the northwest corner. Rainfall only appears to penetrate to the water table along the arroyo channels and other surface drainage features.

- Groundwater gradients vary from relatively steep $(0.02 \mathrm{ft} / \mathrm{ft})$ in the northeast corner of LLNL to fairly flat $(0.001$ $\mathrm{fU} / \mathrm{ft}$ ) toward the west. Average groundwater velocity without pumping is about $70 \mathrm{ft} / \mathrm{year}$.

- Regional groundwater flow is generally westward, locally stratified and primarily horizontal, but flowpaths deepen west of the site.

- Pumping tests and the distribution of VOCs indicate a high degree of horizontal subsurface communication. Lesser communication in the vertical direction and the layered alluvium prevent significant downward migration of VOCs.

- Pumping tests also revealed a wide range (spanning nearly four orders of magnitude) of hydraulic conductivities. This is typical of heterogeneous alluvial sediments.

Area-specific aquifer parameters were estimated as:

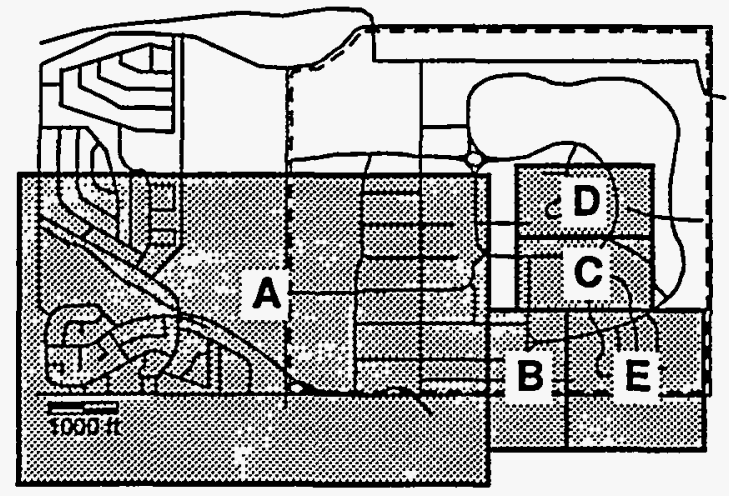

\begin{tabular}{ccccc} 
Area & $\begin{array}{c}\text { Geometric } \\
\text { of data } \\
\text { points }\end{array}$ & $\begin{array}{c}\text { Mean } \\
\text { Hydraulic } \\
\text { Conductivity } \\
{[\mathrm{ft} \text { d] }}\end{array}$ & $\begin{array}{c}\text { Hydraulic } \\
\text { Gradient }\end{array}$ & $\begin{array}{c}\text { Velocity } \\
{[\mathrm{fty}]}\end{array}$ \\
\hline A & 64 & 5.6 & 0.002 & 14 \\
B & 24 & 3.2 & 0.001 & 4 \\
C & 15 & 3.1 & 0.005 & 19 \\
D & 12 & 4.4 & 0.005 & 27 \\
E & 48 & 2.4 & 0.012 & 35
\end{tabular}

- Velocities are calculated based upon a porosity of 0.30 and are applicable only to the area specified. When considering conductivity and velocity over larger areas at $L N L$, considerably higher values are appropriate. 


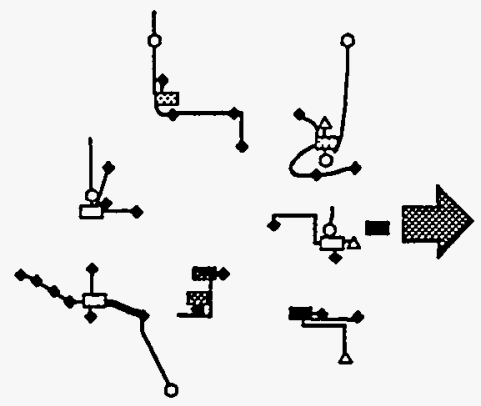

7 separate extraction well networks employing over 75 extraction \& injection wells at over 24 locations.

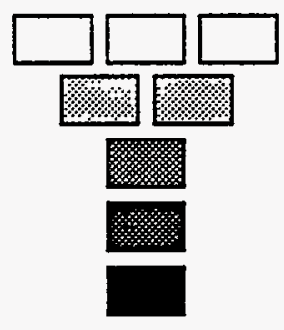

8 groundwater treatment facilities employing 5 different treatment systems (see legend at bottom of page for explanation of symbols).

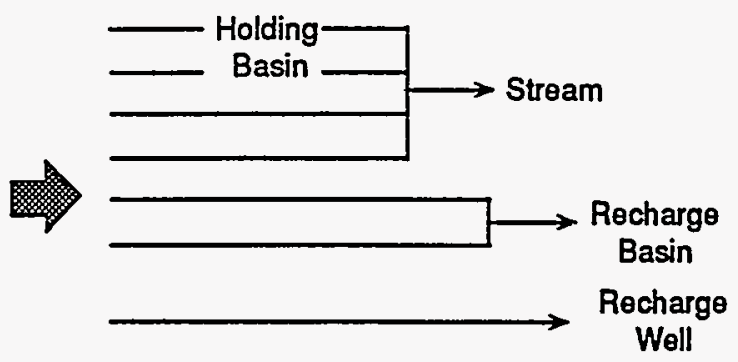

Passage through existing pipelines, drainage retention basins and trenches to either recharge points, streams, or diverted to facility irrigation and cooling systems.

\section{Extraction Well Network \& Treatment Plant Locations}

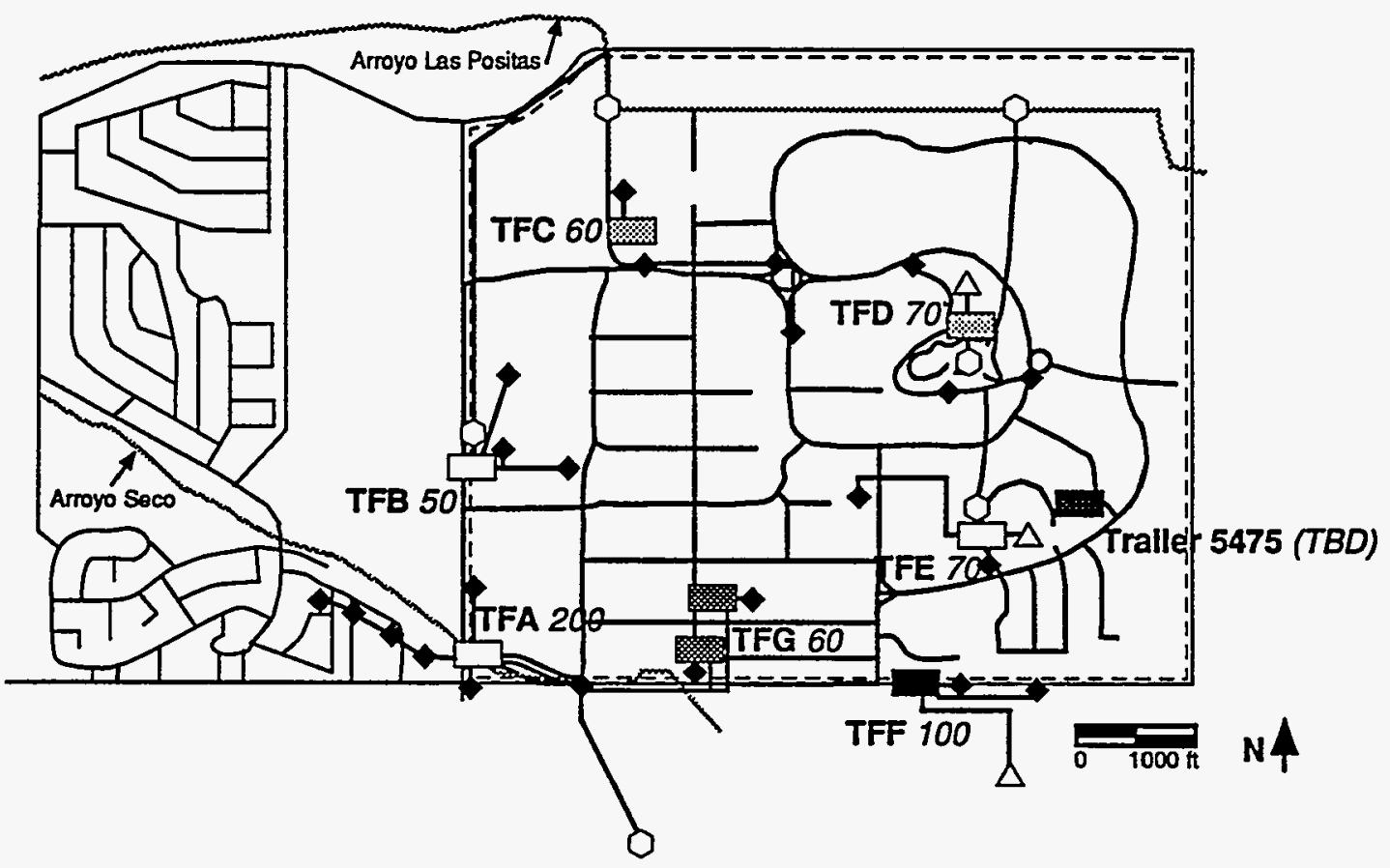

\begin{tabular}{lllllllll} 
TREATMENT FACILITY & A & $\boldsymbol{B}$ & $\boldsymbol{C}$ & $\boldsymbol{D}$ & $\boldsymbol{E}$ & $\boldsymbol{F}$ & $\boldsymbol{G}$ & $\begin{array}{c}\text { Trailer } \\
5475\end{array}$ \\
\hline \# of Extraction Locations & 7 & 3 & 4 & 3 & 2 & 2 & 2 & TBD \\
\# of Extraction Wells & 22 & 7 & 9 & 12 & 17 & 9 & TBD & TBD \\
\# of Piezometers/Monitoring Wells & 68 & 21 & 30 & 36 & 41 & 20 & TBD & TBD
\end{tabular}

Note: TBD = to be determined

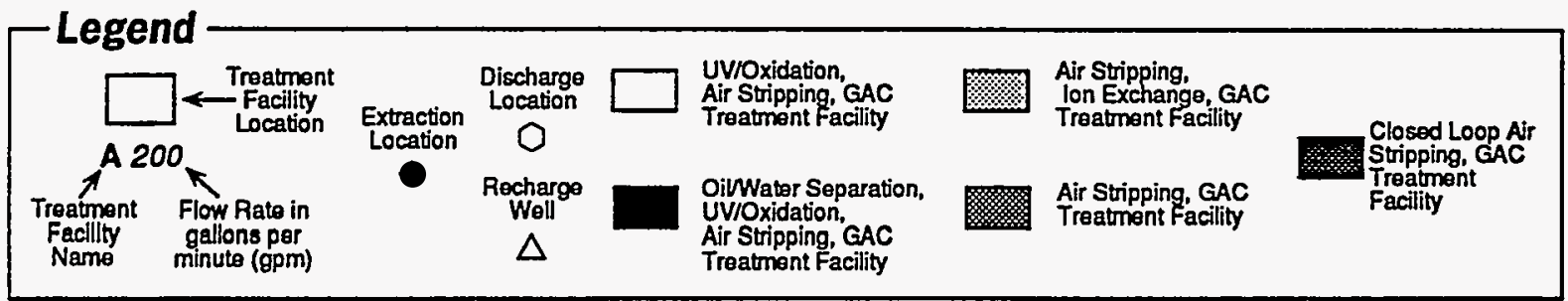




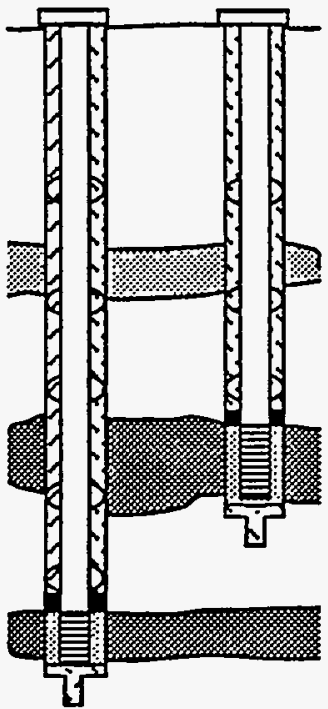

Extraction Woll Clustor with Single Scroen Wells

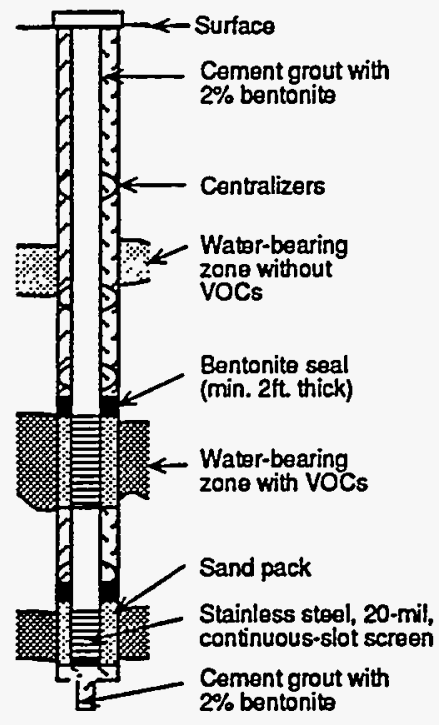

Multiple Screon Extraction Well
An extraction well design decision making process was instituted at LLNL. Decisions were based upon a systematic consideration of :

- the suitability of existing wells for extraction,

- contaminant concentration levels in groundwater and intervening fine-grained sediments, and

- order-of-magnitude differences in VOC concentrations among adjacent permeable zones.

Either existing wells are used for extraction or one or more single screen or multiple screen extraction wells are installed.

The objectives are to:

- pump permeable zones selectively and/or at different flow rates,

- assess flow and contaminant mass removal rates for individual zones, and

- avoid clogging well screens and treatment systems with fine-grained sediment in water pumped from screened silt and clay.

\section{Treatment System Overview}
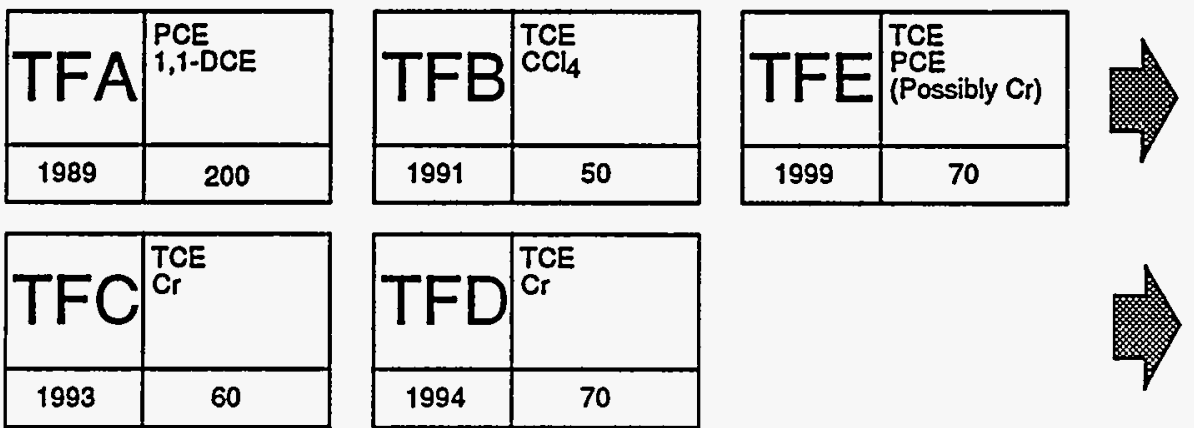

\begin{tabular}{|c|l|}
\hline TFF & $\begin{array}{l}\text { FHCS } \\
1,2-D C A \\
\text { TCE } \\
\text { (Possibly lead) }\end{array}$ \\
\hline 1993 & 100 \\
\hline
\end{tabular}

UV/Oxidation<smiles>[V][V]</smiles>

Diffuse Aeration with GAC Treatment of Offgas

Air Stripping by Diffuse
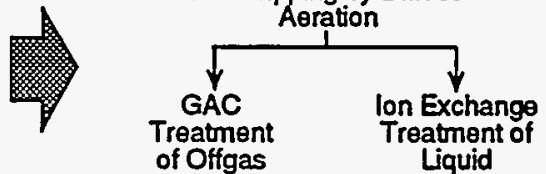

OilWater Separation

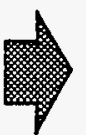

uvidxidation<smiles>[V][V]</smiles>

Diffuse Aeration with GAC

Treatment of Offgas

- Treatment Facility G, scheduled for initial operation in 1996, will likely be installed as 2 separate portable facilities to treat VOC contaminated groundwater at a total rate of $60 \mathrm{gpm}$ by air stripping followed by GAC treatment of offgases.

- The Trailer 5475 facility is scheduled for detailed design in 1997 or 1999.

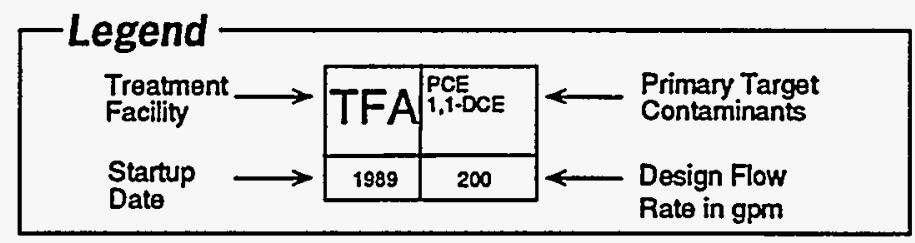


Treatment System Schematics

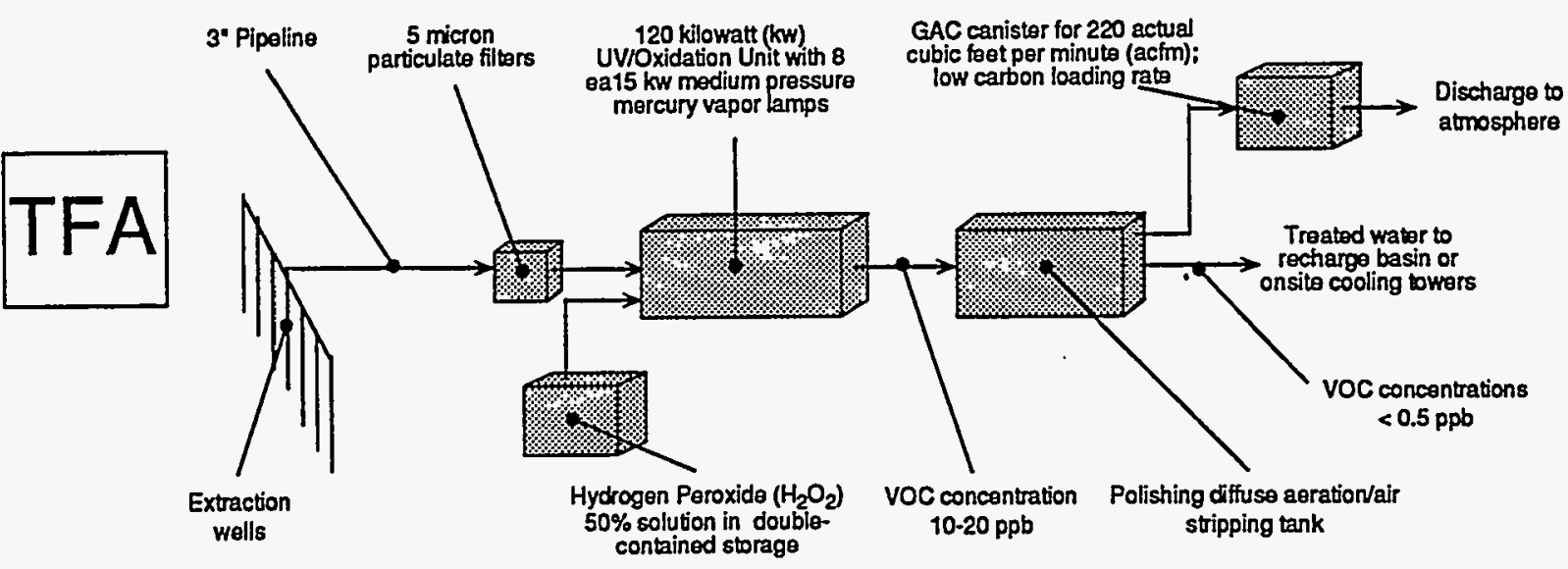

\section{T - Similar configuration to Treatment Facility A but scaled down for lower flow rates}

- Dișcharge to a drainage ditch leading to Arroyo Las Positas

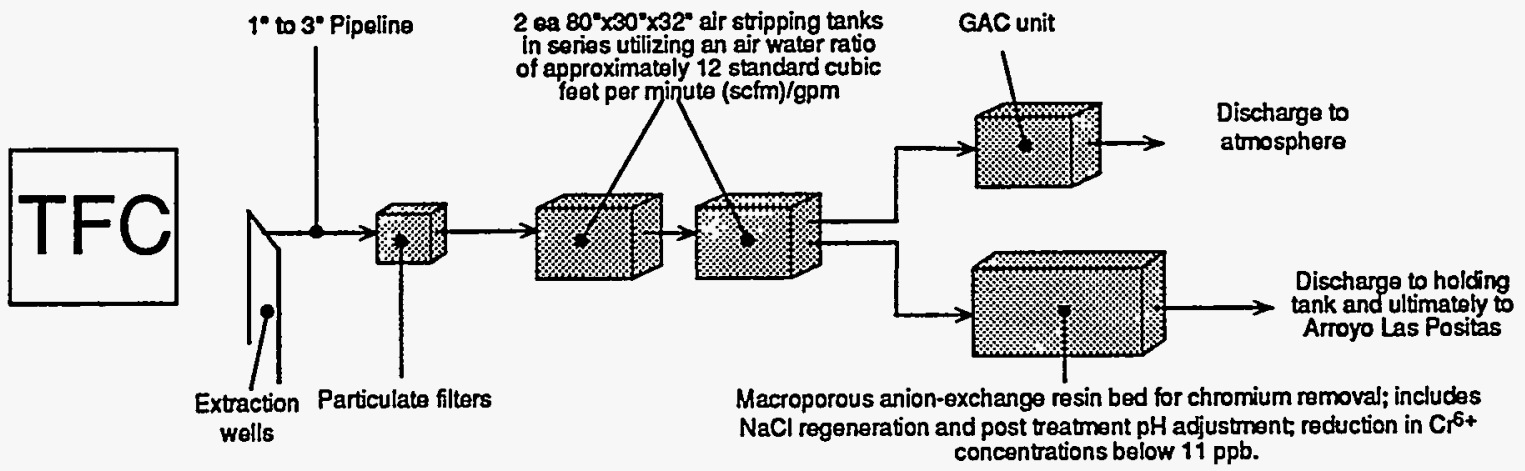

- Similar configuration to Treatment Facility C.

- A series/parallel air stripping tank arrangement involving thre日 units was selected:

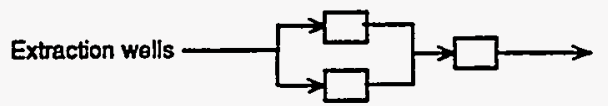

- Similar configuration to Treatment Facility A

- Potential need for add-on ion exchange treatment unit for chromium removal

- Two polishing diffuse aeration air strippers in series

- Discharge to drainage retention basin 


\section{Treatment System Schematics (continued)}

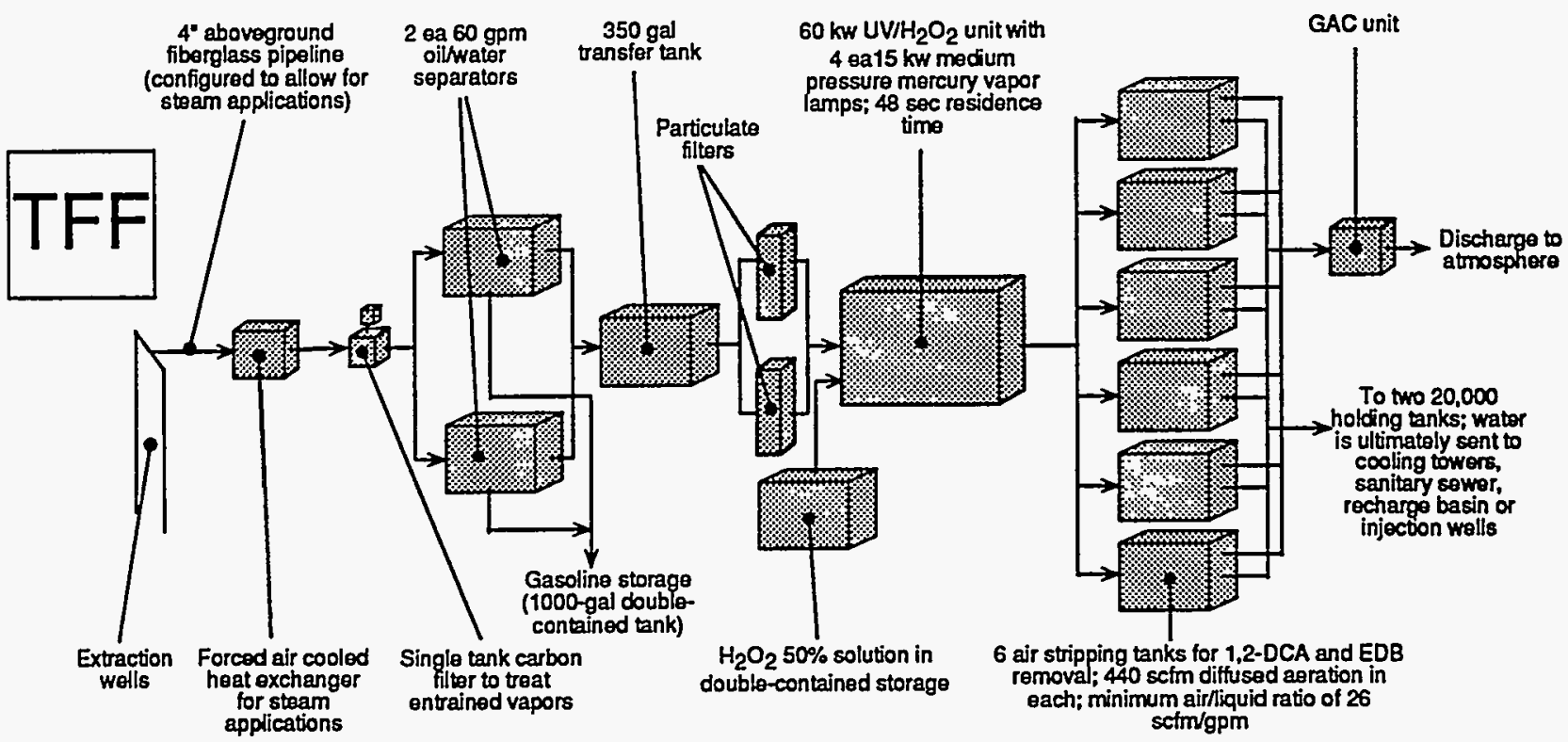

- Treatment Facility $F$ has an accompanying soil vapor extraction system and is also the site of a technology demonstration program for Dynamic Underground Stripping (Utilizing steam injection to remove gasoline).

- Treatment facilities A, B, C and D are enclosed in buildings and set atop concrete pads.

- Safety features for the facilities include automatic shutdown interlock control systems to prevent spills or discharging.

- Inorganic chemistry was major design consideration, particulary for Treatment Facilities C,D,E and F; scaling will be controlled through routine maintenance or the addition of polyphosphates.

- The initial seven treatment facility locations were selected to minimize piping requirements and provide efficient discharge routes.

- Spent GAC with VOCs is shipped offsite for regeneration or disposal. Sodium chloride solution with chromium is disposed as hazardous waste. 


\section{Performance Criteria}

The LLNL Groundwater Project is designed to satisfy numerous chemical-specific, location-specific and actionspecific requirements. However, the driving force for determination of cleanup are Federal and California Maximum Contaminant Levels (MCLs) for drinking water. The primary contaminants, PCE and TCE, have MCLs of $5 \mathrm{ppb}$. The project is also designed to:

- Prevent migration of contaminated groundwater to nearby offsite water supply wells.

- Cleanup offsite plume components.

- Achieve cleanup goals in 50 years or less.

\section{Remediation History}

The LLNL groundwater treatment program is in the early stages of implementation. Treatment facilities $A, B, C$ and $F$ have operated with some of the planned extraction wells since their startup. Treatment facility D (TFD) began operation in October 1994. More detailed performance information is becoming available. The general remediation strategy employed and preliminary data gathered to date are presented in the following "Performance" subsections.

\section{Remediation Plan}

The overall long-term environmental remediation strategy for the LLNL Livermore Site uses ground water extraction and treatment that is based on an hydraulic control philosophy including:

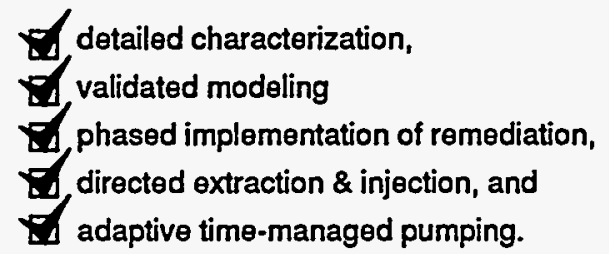

This unique approach will:

Cnable testing and optimization of extraction, injection and treatment system designs, efficiencies, and extents of hydraulic and contaminant capture prior to full-scale or widespread use;

Comploy dynamic management of wellfields and optimization of cleanup through field monitoring and modeling; and

rensure continued regulatory and community acceptance.

Dynamic management of the wellfield involves operation of individual wells either continuously, intermittently, or not at all depending upon the results of field monitoring and the estimates of models and optimization routines:

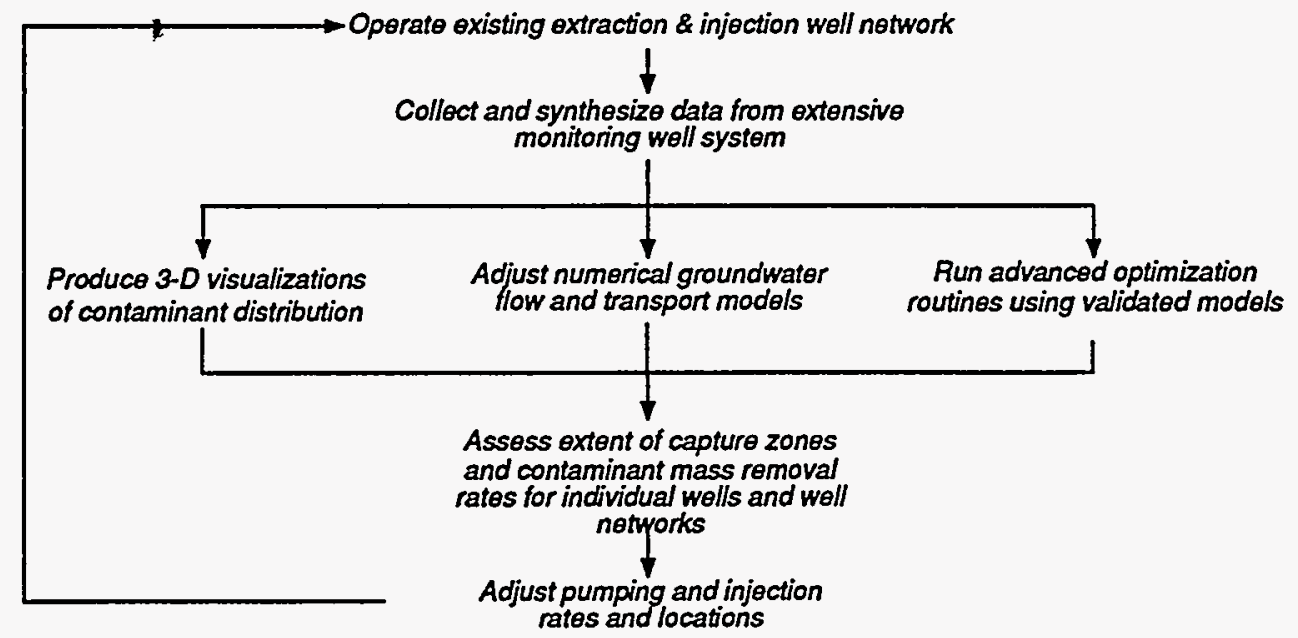




\section{System Throughput}

- TFA treated approximately 87.3 million gal from Sept 1989 to Oct 1994 and 4.2 million gal during the 3rd quarter of 1994.

- TFB treated approximately 21.2 million gal from Oct 1990 to Oct 1994.

- TFC treated approximately 1.7 million gal from Oct 1993 to Oct 1994.

- TFD teated approximately 71.1 thousand gal from Sept 1994 to Oct 1994.

- TFF treated approximately 15 million gal groundwater from Feb 1993 to Oct 1994 and 2.8 million $\mathrm{ft}^{3}$ of vapor during 3rd quarter 1994.

\section{System Downtime}

- TFA has operated almost full time since Sept 1989 to Jan 1993; TFA was shut down in May 1991 to upgrado the system from 100 to $150 \mathrm{gpm}$.

- In Jan 1992,20 ppb Crot was found in TFB effluent (discharge limit is $11 \mathrm{ppb}$ ). The system was shut down and the chromium source was determined to be a combination of naturally occurning levels in groundwater and leaching from paints coating the groundwater

Hydrodynamic Performance

TFA and TFB are expected to establish hydraulic control of the offsite portion of the VOC plume. Modeling efforts anticipate the creation of hydraulic capture zones shown at right when all treatment facilites are fully operational.

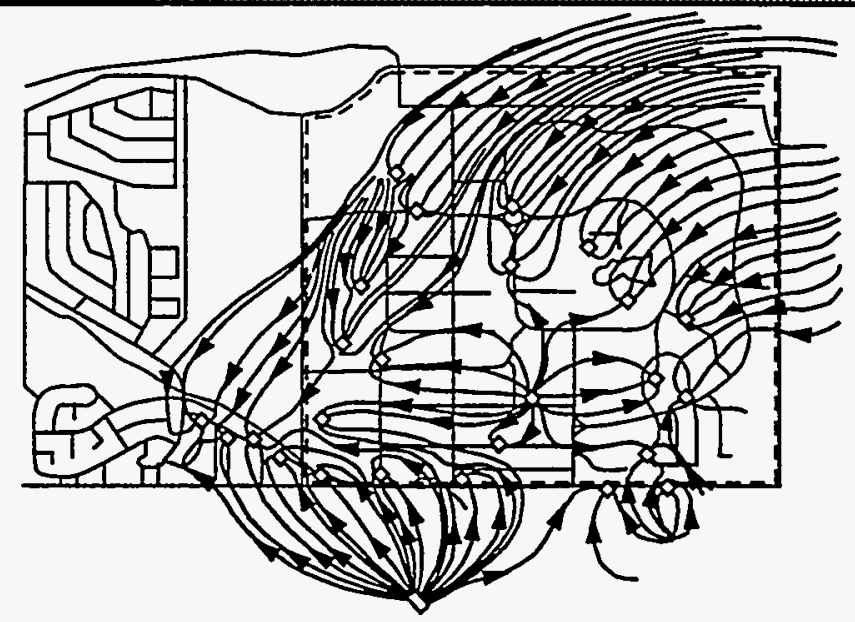

\section{Treatment Performance}

\section{Influent vs Effluent}

UV/Oxldation Unlt Treatment Efflciency Porformance results, comparing influent vs. effluent concentrations

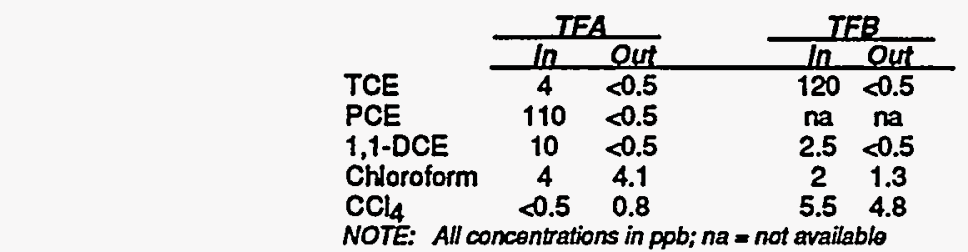

Treatment Facility Destruction Efficiency

\begin{tabular}{|c|c|c|c|c|c|c|c|c|c|c|c|}
\hline & & sign. & erage & ffuen & Conce & trations & {$[p p b]$} & & $\begin{array}{r}\text { Tre } \\
\text { Disch }\end{array}$ & $\begin{array}{l}\text { ated Effluen } \\
\text { arge Limits }\end{array}$ & {$[p p b]$} \\
\hline TCE & $\begin{array}{c}\text { TFA } \\
7\end{array}$ & $\begin{array}{l}\text { TFB } \\
300\end{array}$ & $\begin{array}{c}\text { TFC } \\
20\end{array}$ & $\begin{array}{l}\text { TFD } \\
875\end{array}$ & $\begin{array}{l}\text { TFE } \\
860\end{array}$ & $\begin{array}{l}\text { TFF } \\
200\end{array}$ & $\begin{array}{c}\text { TFG-1 } \\
38\end{array}$ & $\begin{array}{c}T F G-2 \\
17\end{array}$ & $\begin{array}{c}\text { NPDES } \\
-\end{array}$ & WDO & LWRP \\
\hline PCE & 280 & 40 & 5 & 28 & 60 & 10 & 13 & 22 & 4 & - & . \\
\hline 1,1-DCE & 12 & 10 & 2 & 11 & 20 & 10 & 11 & 1 & - & - & - \\
\hline 1,2-DCE (cis\&trans) & 4 & 3 & $=$ & 1 & 1 & - & - & 2 & - & - & - \\
\hline $1,1,1-\mathrm{TCA}$ & 5 & 1 & - & - & - & 3 & 3 & $=$ & - & - & - \\
\hline $1,1-D C A$ & 5 & 5 & - & 1 & - & - & - & - & - & - & - \\
\hline $1,2-D C A$ & - & 1 & - & 20 & 2 & 130 & - & - & - & - & - \\
\hline Chloroform & 10 & 10 & 3 & 5 & 9 & 20 & 15 & 4 & - & - & - \\
\hline $\mathrm{CCL}_{4}$ & - & 2 & - & 20 & 3 & 10 & 7 & 3 & - & - & - \\
\hline Freon 113 & 5 & 10 & 100 & 1 & 8 & 10 & 7 & 3 & - & - & - \\
\hline Freon 11 & - & - & - & 148 & - & - & - & - & - & - & - \\
\hline ED & - & - & - & - & - & 10 & - & - & 0.02 & - & - \\
\hline Benzene & - & - & - & - & - & 20,000 & - & - & 0.7 & - & - \\
\hline BTEX & - & - & - & - & - & 65,000 & - & - & - & - & 250 \\
\hline Total VOCs & 328 & 382 & 130 & 1,110 & 963 & 403 & 99 & 50 & 5 & 5 & 1000 \\
\hline Load & - & - & - & - & - & 30 & - & - & 5.6 & 500 & 200 \\
\hline Crt & - & 20 & 30 & 11 & 4 & - & 21 & 9 & 11 & 500 & - \\
\hline $\mathrm{Cr}$ & - & 20 & 30 & 11 & 4 & - & 21 & 9 & 50 & $1,700,000$ & 620 \\
\hline
\end{tabular}

NOTE: $\quad \because=$ not part of design basis; negligible anticipated influent; NPDES = National Pollution Discharge Elimination System permit; WDO = state Wasto Discharge Order Requirement; LWRP = Livermore Water Reclamation Plant requirement. 


\section{Treatment Performance (continued)}

Effects on Plume

Current agreements specify that all treatment facilities will be operated until in situ VOC concentrations are below MCLs for 2 years. Final closure will be described in the future Compliance Monitoring Plan.

Contaminant Concentrations vs Time at Influent

At TFA, influent PCE concentrations have been reduced from $900 \mathrm{ppb}$ to $150 \mathrm{ppb}$ since startup.

Contaminant Mass Removal

Information on the total volume of VOCs removed by each treatment facility has only recently been collected as the facilities have become more fully operational. From start of operation through September 1994 mass removal data were:

\begin{tabular}{ccc}
$\begin{array}{c}\text { Treatment } \\
\text { Facility }\end{array}$ & VOC Mass & Ave. Extraction Rate \\
Removed & as of Sept 1994 \\
\hline TFA & $44.4 \mathrm{~kg}$ & $150 \mathrm{gpm}$ \\
TFB & $8.5 \mathrm{~kg}$ & $20 \mathrm{gpm}$ \\
TFC & $0.9 \mathrm{~kg}$ & $22 \mathrm{gpm}$ \\
TFD & $0.04 \mathrm{~kg}$ & $8 \mathrm{gpm}$ \\
TFF & 10,200 gal of liquid equivalent gasoline & $50 \mathrm{gpm}$
\end{tabular}


- Remedial design reports were issued in 1993 and 1994 for Treatment Facilities (TF) A, B, C, D, E and F. The cost data below are from these reports. The data reflect actual costs for design and construction of TFA and TFB and represent projected costs in 1993 dollars for TFC, TFD, TFE and TFF.

- Technology evaluations, preliminary designs, final designs and most of the construction effort for the LLNL groundwater treatment project were performed by LLNL personnel. When necessary, subcontractors were competitively procured for specialized construction assignments. The costs below reflect the internal costs of design and construction activities performed by LLNL staff.

\section{Capital Costs}

TFA (1)

Building (including piping \& power) $\$ 472,500$

Recharge basin, access road \& fence $\quad 116,500$

Polishing tank \& installation $\quad 20,000$

UV unit for 100 GPM rate (60 kw) $\quad 63,000$

UV unit for 150 GPM rate (120 kw) $\quad 150,000$

UV upgrade design \& installation $\quad \begin{array}{r}73,700 \\ \quad \$ 895,700\end{array}$

$\$ 895,700$
TFD (2)

Building (including design, construction, piping \& power)

Process equipment

lon-exchange unit \& equipment 18,000

Activation cost

Material procurement charge $(9.7 \%)$

40,000

16,500

$\$ 1,406,500$
TFB (1)

Building (induding design \& inspection) $\$ 3,500$

Piping \& power to well heads $\quad 5,000$

$60 \mathrm{kw}$ UV/Oxidation unit $\quad 80,000$

Electrical modification $\quad 9,200$

Influent pipeline modifications $\quad 23,200$

$\$ 446,400$

TFC (2)

Building (including design, construction, piping \& powr)

Air stripper \& associated equipment

Ar striper \& associated equipment $\quad 130,000$

lon-exchange unit \& equipment $\quad 162,000$

Activation cost

40,000

Material procurement charge $(9.7 \%) \quad 28,324$

$\$ 1,440,324$

TFE (2)

Building (including dasign, construction, piping \& power)

$60 \mathrm{kw}$ UV/Oxidation unit

Process equipment

$\$ 1,000,000$

140,000

lon-exchange unit

75,000

60,000

Activation cost

40,000

Material procurement charge $(9.7 \%)$

TFF (2)

TFF piping \& power

Process equipment

Vapor modification (for stoam

underground stripping demonstration) $\quad 159,900$

Discharge pipeline

Activation (construction support only)
$\$ 1,341,700$

$\$ 1,511,700$

400,000

87,000

80,000

$\$ 2,238,600$

\section{Operating Costs}

\begin{tabular}{lcccccc} 
& TFA (1) & TFB(1) & TFC(2) & TFO(2) & TFE(2) & TFF(2) \\
\hline Labor & $\$ 80,000$ & $\$ 80,000$ & $\$ 610,000$ & $\$ 610,000$ & $\$ 590,000$ & $\$ 700,000$ \\
Materials & 50,000 & 50,000 & 210,000 & 210,000 & 210,000 & 100,000 \\
Maintenance Contract & 34,000 & 20,000 & - & - & - & - \\
LLNL Overhead & - & - & 110,000 & 110,000 & 100,000 & 100,000 \\
\hline \hline Total & $\$ 164,000$ & $\$ 150,000$ & $\$ 930,000$ & $\$ 930,000$ & $\$ 900,000$ & $\$ 900,000$
\end{tabular}

NOTES (1) - TFA \& TFB capital and operating costs were determined prior to current project management system and are not inclusive of all costs. (2) - The TFC, TFD, TFE and TFF cost accounting methods attempt to include all internal UNL costs associated with operation and maintenance.

- Labor cost estimates for TFC through TFF include hydrogeologists, chemists, engineers, technicians, analysts, LLNL hazardous waste management specialists and plant engineering support. This labor requirement is expected to steadily decrease over the 53-year projected time of operation (83\% effort for years 6-10, 67\% for years $11-15$ and $50 \%$ effort for years $15-53$ ). 


\section{REGULATORY/INSTITUTIONAL ISSUES}

- All facilities comply with the Bay Area Air Quality Management District standards for VOC release. Groundwater discharges to the storm sewer are also controlled by National Pcllutant Discharge Elimination System (NPDES) requirements (currently TFB, TFC and TFD). Groundwater discharges to the recharge basin are controlled by the San Francisco Bay Regional Water Quality Control Board (RWQCB) Waste Discharge Order Requirements (currently TFA). Groundwater discharge to the sanitary sewer is controlled by Livermore Water Reclamation Plant (LWRP) requirements (currently TFF).

- An active and ongoing public involvement program has served to coordinate discussions and commentary from an interested and concerned local population.

- An extensive and detailed quantitative risk assessment involving fate and transport modeling of contaminants was performed for the LLNL Livermore Site. The best estimate of noncarcinogenic risk produced a Hazard Index $(\mathrm{HI})$ of 1.6E-3 indicating little potential for chronic health effects. However, an EPA health conservative (worst case) risk assessment method produced cancer risks as high as 1E-3 and HI's equalling 1 which exceeds EPA's acceptable cancer risk range at Superfund sites of $1 \mathrm{E}-4$ to $1 \mathrm{E}-6$ and indicate the potential for chronic health effects. The best estimate of the maximum incremental risk of developing cancer was 2E-7 from a lifetime exposure to VOCs in downtown Livermore well water. No members of the public are currently exposed to VOCs from the use of wells near LLNL.

\section{Cleanup Criterla}

Currently, treatment systems will be operated until groundwater concentrations of target contaminants are below MCLs for two years. Final closure will be discussed in the Future Compliance Monitoring Plan.

\section{SCHEDULE}

Major Mllestones
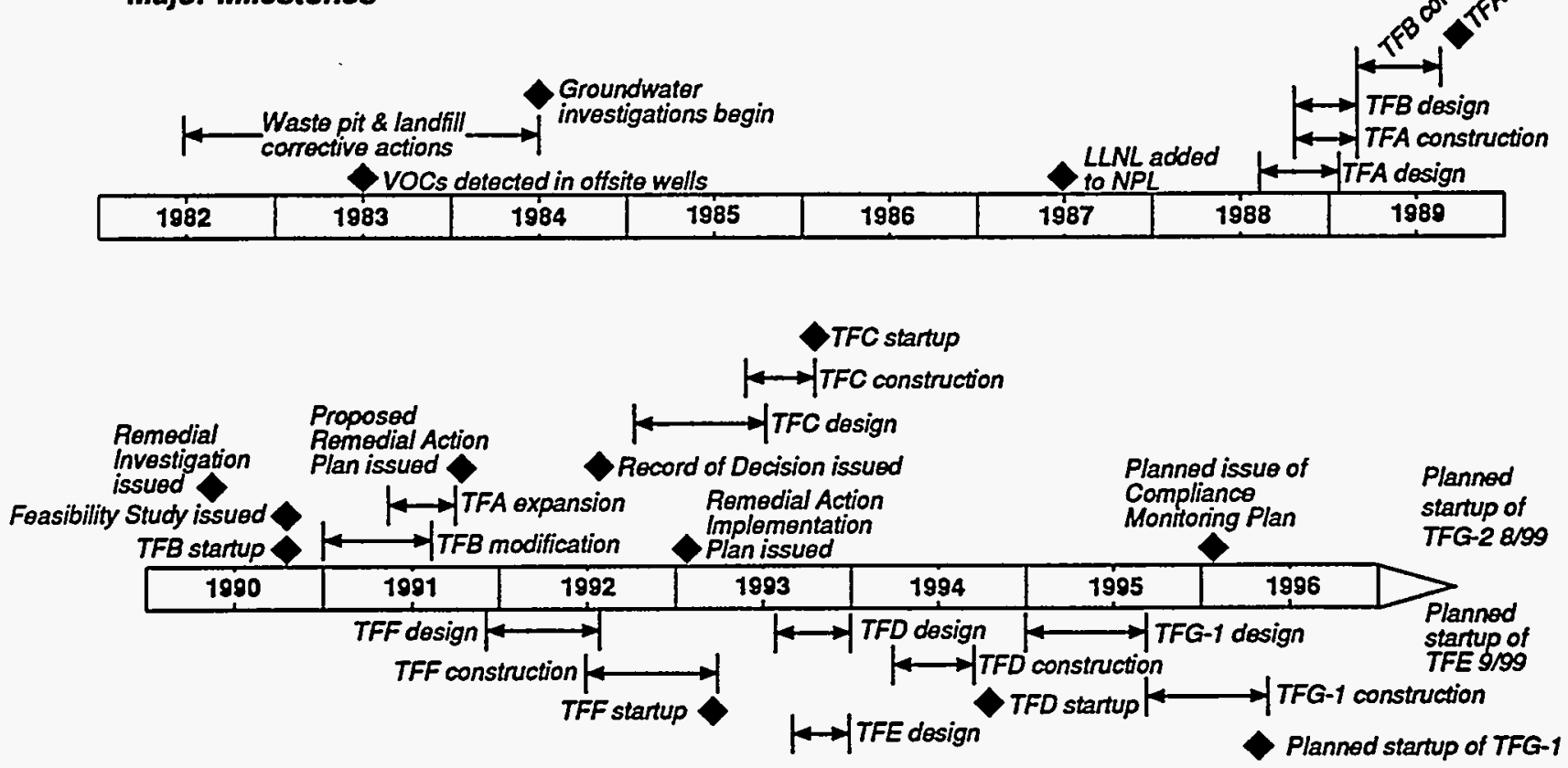
LESSONS LEARNED

Implementation Considerations

- Comprehensive subsurface site characterization efforts have provided significant project benefits. They have allowed for optimal placement of extraction wells to maximize contaminant removal rates and provide hydraulic control of plumes. The methodology is cost-effective in light of the high cost of misplaced wells.

- Conducting pilot-scale or field treatability tests for standard groundwater treatment unit operations proved useful in design and construction of treatment systems. Air stripping VOCs also removes carbon dioxide which causes calcium carbonate scaling and a rise in pH. Measures to prevent or reduce scaling were tested for effectiveness prior to full-scale implementation. Addition of carbon dioxide slowed scaling. However, addition of polyphosphate eliminated scaling at TFF. Polyphosphate will be used at the other facilities as needed.

- Transparent piping at the ion-exchange resin treatment units for Cre+ removal were a design upgrade that allowed for easier verification of system conditions during operation.

- Phased implementation of treatment system capacity was compatible with the ne日d for maintaining operability. Integration of geologic and engineering design for facilities and pipelines is essential to construct high performance systems cost-effectively.

\section{Technology Limitations}

- To maintain high UV VOC destruction efficiency, UV lamps must be cleaned to prevent buildup of mineral coatings from inorganic groundwater components.

- $\mathrm{H}_{2} \mathrm{O}_{2}$ concentration at TFB was increased from 30 to $100 \mathrm{ppm}$ to reduce $\mathrm{Cr}+$ which has a low discharge limit, to $\mathrm{Cr}^{3+}$, which has a higher discharge limit. Residual levels of $\mathrm{H}_{2} \mathrm{O}_{2}$ exiting the UVIOxidation unit at TFB may be the cause of low fish survivability tests of TFB effluent. Liquid-phase GAC treatment to keep $\mathrm{H}_{2} \mathrm{O}_{2}$ levels below $10 \mathrm{ppm}$ was successfully bench-tested and will be installed after the UV/Oxidation unit.

- Current projections of cleanup duration exceed 50 years. Even with anticipated reductions in project staffing requirements, long-term operation and maintenance costs dominate project economics.

\section{Future Technology Selection Considerations}

- Treatment configurations can be employed to treat mixtures of chlorinated alkanes and alkenes, FHCs, and metals. UV/Oxidation treatment is effective on alkenes but ineffective on alkanes. Followup treatment with an air stripping process removes residual alkanes. Simple air stripping, while not a destruction technology, may be preferable in some instances. lon-exchange resin treatment as a final polishing effort to remove metals was a straightforward addition to other treatment trains.

- The open and ongoing dialog with regulators and the local community has greatly contributed to the project's progress. LLNL personnel share all data and discuss work-in-progress with regulators during monthly and quarterly scheduled meetings as well as at seminars and workshops convened on an as-needed basis. The approach has secured early concurrence from regulators during ongoing technology-related decision making.

- A rigid Record of Decision (ROD) may have created obstacles to ongoing remediation strategy planning efforts in some instances. A more flexible ROD might allow improvements in the remediation approach which arise during the long project time frame to be implemented more easily. Flexibility was an important issue in maintaining consistency with anticipated funding levels and project priorities.

- Flexibility of remedial strategy and technology selection was especially important in light of shifts in project priorities. Over time, greater emphasis has been placed on offsite plume margin control compared to onsite source controlvcleanup to meet budget requirements and to address community concerns. 


\section{ANALYSIS PREPARATION}

This analysis was prepared by:

Stone \& Webster Environmental

Technology \& Services

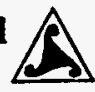

245 Summer Street

Boston, MA 02210

Contact: Bruno Brodfeld (617) 589-2767

Assistance was provided by the

LAWRENCE LIVERMORE NATIONAL LABORATORY

ENVIRONMENTAL RESTORATION DIVISION

which supplied key information and reviewed report drafts.

for:

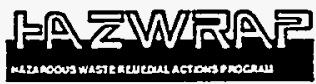

HAZARDOUS WASTE REMEDIALACTIONS PROGRAM

Environmental Restoration and Waste Management Programs

Oak Ridge, Tennessee 37831-7606

managed by

MARTIN MARIETTA ENERGY SYSTEMS

for the

U.S. Department of Energy

under Contract DE-AC05-84OR-21400

This analysis was funded by:

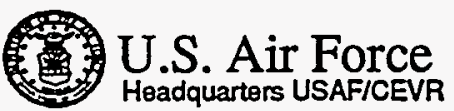

This analysis accurately reflects the performance and costs of the remediation:

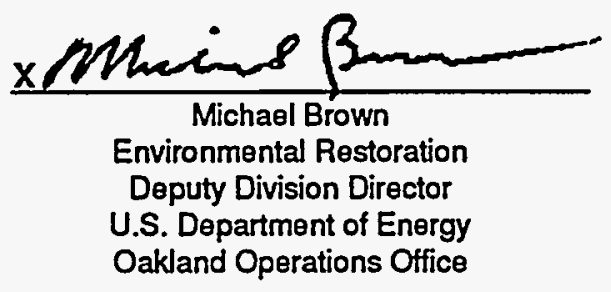


Major Sources For Each Section

Site Characteristics:

Treatment System:

Performance:

Cost:

Regulatory/Institutional lssues:

Schedule:

Lessons Learned:
Source \#s (from list below) 1, 3, 9,11 and 12

Source \#s 5, 6, 7, 8 and 9

Source \#s 4, 5, 6 and 7

Source \#s 5, 6 and 7

Source \#s 1, 4 and 8

Source \# 8

Source \#s 1, 2, 3 and 4

\section{Chronological List of Sources and Additional References}

1. Personal communications with Bob Bainer, Lawrence Livermore National Laboratory, Environmental Restoration Division, (510) 422-4635, November 1994.

2. Personal communications with John Ziagos, Lawrence Livermore National Laboratory, Environmental Restoration Division, (510) 422-5479, October 1994.

3. Personal communications with Richard Blake, Lawrence Livermore National Laboratory, Environmental Restoration Division, (510) 422-9910, November 1994.

4. Hoffman, J., M. Dresen, R. Bainer, E. Folsom, B. Qualheim, and J. Zlagos (Eds.) (1994), LLNL Ground Water Project - Quarterty Progress Report September 1994, Lawrence Livermore National Laboratory, Livermore, CA. (UCRL-AR-115640-94-3).

5. Berg, L.L., M.D. Dresen, E.N. Folsom, J.K Macdonaid, R.O. Devany, R.W. Bainer, R.G. Blake and J. Ziagos (Eds.) (1994), Remedial Design Report No. 3 for Treatment Facilities D and E, Lawrence Livermore National Laboratory, Livermore Site, Lawrence Livermore National Laboratory, Livermore, CA. (UCRL-AR-113880).

6. Berg, L.L., M.D. Dresen, E.N. Folsom, J.K Macdonald, R.O. Devany, and J. Ziagos (Eds.) (1993), Remedial Design Report No. 2 for Treatment Facilities C and F, Lawrence Livemore National Laboratory, Livermore Site, Lawrence Livermore National Laboratory, Livermore, CA. (UCRL-AR-112814).

7. Boegel, A.J., M.D. Dresen, E.N. Folsom, P. Thiry, J.P. Ziagos, L.L. Berg, and J.K Macdonald (Eds.) (1993), Remedial Design Report No. 1 for Treatment Facilities $A$ and B, Lawrence Livermore National Laboratory, Livermore Site, Lawrence Livermore National Laboratory, Livermore, CA. (UCRL-AR-110576).

8. Dresen, M.D., J.P. Ziagos, A.J. Boegel, E.M. Nichols, and J.K Macdonald (Eds.) (1993), Remedial Action Implementation Plan for the LLNL Livermore Site, Livermore, California, Lawrence Livermore National Laboratory, Livermore, CA. (UCRL-AR-110532).

9. U.S. Department of Energy (DOE) (1992), Record of Decision for the Lawrence Livermore National Laboratory Livermore Site, Lawrence Livermore National Laboratory, Livermore, CA. (UCRL-AR-109105).

10. U.S. Department of Energy (DOE) (1991), Proposed Remedial Action Plan for the Lawrence Livermore National Laboratory Livermore Site, Livermore, California, Lawrence Livermore National Laboratory, Livermore, CA. (UCRL-AR-105577).

11. Isherwood, W.F., C.H. Hall and M.D. Dresen (Eds.) (1990), CERCLA Feasibility Study for the LLNL Livermore Site, (including errata of October 1991), Lawrence Livermore National Laboratory, Livermore, CA. (UCRL-AR110532).

12. Thorpe, R.K., W.F. Isherwood, M.D. Dresen, and C.P Webster-Scholten (Eds.) (1990), CERCLA Remedial Investigation Report for the LLNL Livermore Site, Lawrence Livermore National Laboratory, Livermore, CA. (UCAR-10299). 
TECHNOLOGY APPLICATION ANALYSIS

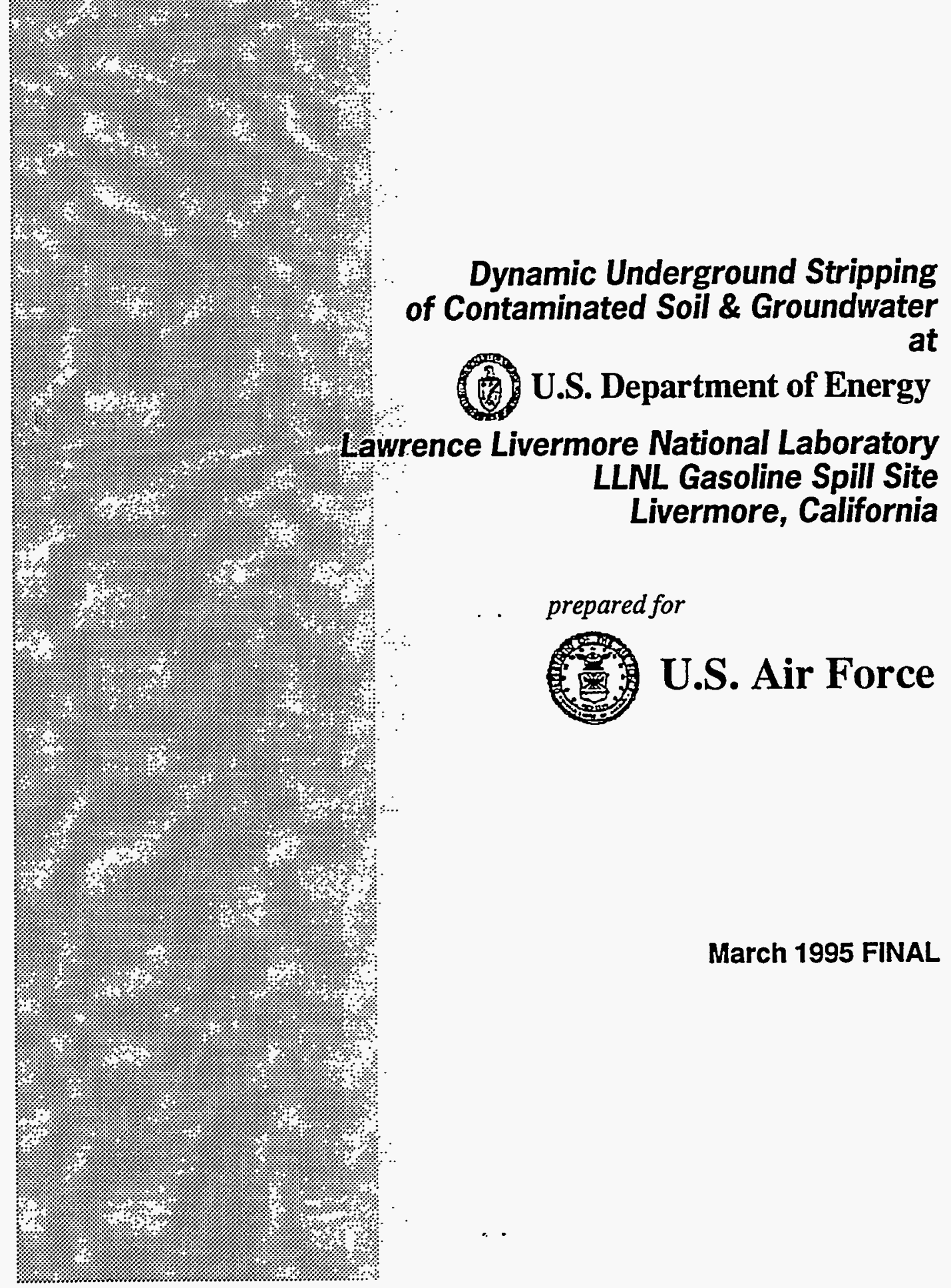


SITE

Lawrence Livermore National Laboratory (LLNL)

LLNL Gasoline Spill Site Livermore, California
NTECHNOLOGY APPLICATION

This analysis reports on the use of Dynamic Underground Stripping (DUS) technology to remediate soil and groundwater above and below the water table contaminated with fuel hydrocarbons (FHCs) from a former gasoline spill. DUS employs a combination of steam injection with vacuum extraction, electrical heating, and underground imaging.

\section{SITE CHARACTERISTICS}

\section{Site History/Release Characteristics}

- The 800 acre LLNL site was converted from agricultural use into a flight training base and aircraft assembly and repair facility by the Navy in 1942. In 1951, the Atomic Energy Commission converted the site into a weapons design and basic physics research laboratory. Later site missions have included programs in biomedicine, energy, lasers, magnetic fusion energy, and environmental science.

- Initial releases of hazardous materials occurred in the mid to late 1940s. There is also evidence that subsequent localized spills, leaking tanks and impoundments, process cooling water and landfills released VOCs, FHCs, lead, chromium and tritium to sediments and groundwater primarily from 14 major areas of concern.

- Between 1952 and 1979, based upon inventory records, as much as 17,000 gallons of leaded gasoline was released from underground storage tanks (USTs) in an area now designated the Gasoline Spill Area (GSA).

- Corrective actions taken since 1988 at the GSA have included the removal and sand filling of four USTs, installation of a gas skimmer which removed 100-150 gal of gasoline, soil vapor extraction of about 1900 gal, and intermittent use of a groundwater pump \& treat system using UV/H2O2 treatment. A large subsurface micobiological population indicates that indigenous microbes have metabolized additional gasoline constituents.

\section{Contaminants of Concern}

Contaminants of concern focused on during the remediation are:

Benzene
Toluene
Ethylbenzene
Xylene
1,2-Dichloroethane

Low levels of other chlorinated solvents are also present in the GSA but were not specifically targeted by DUS remediation efforts.

\section{Contaminant Properties}

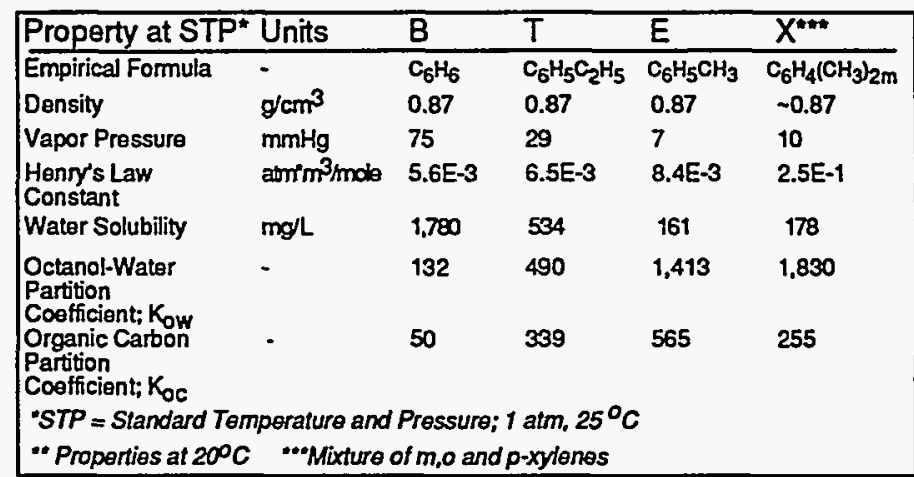

\section{Site Conditions}

- The GSA occupies an approximately $11 / 4$ acre level area at the southern edge of LLNL. The site was formerly a gasoline filling station for use by LLNL vehicles.

- Climate is semiarid with annual precipitation around 14 inches/year.

- Land north and south of the site is zoned for industrial use, high-density urban areas are west of the site and the east side is primarily agricultural. Immediately south of the GSA are facilities owned and operated by Sandia National Laboratory. 


\section{Nature and Extent of Contamination}

- The mass of FHC as gasoline prior to any remediation efforts was estimated based upon soil and groundwater sampling to be approximately $16,000-17,000$ gal: 6,000 in the vadose $20 n e, 10,000-11,000$ in saturated sediments and 100 dissolved in groundwater. Mass volume estimates made immediately prior to application of DUS identified approximately $6,500 \mathrm{gal}$ of gasoline within the treatment zone.

- Concentrations of gasoline were as high as 5,100 ppm in saturated sediments near the center of the vadose zone indicating the likelihood of free phase gasoline. The free phase was trapped within low-permeability sediments by a groundwater table that has risen 10 to $30 \mathrm{ft}$ since the time of the main portion of the release (1979).

- FHC concentrations exceed $10 \mathrm{ppm}$ only in the immediate vicinity of the release point with concentrations decreasing to $1 \mathrm{ppm}$ and $100 \mathrm{ppb}$ at $35.40 \mathrm{ft}$ and 40-45 ft respectively. Benzene levels above $1 \mathrm{ppb}$ (California Maximum Contaminant Level (MCL) is now $0.5 \mathrm{ppb}$ ) are found within $300 \mathrm{ft}$. FHCs are not present below a depth of $150 \mathrm{ft}$.

- Fuel was trapped below the water table by a $20 \mathrm{ft}$ rise in groundwater elevations in the late 1970's from cessation of agricultural pumping.

\section{Contaminant Locations and Hydrogeologic Profiles}

The GSA has been extensively studied since 1984. Over 70 subsurface borings and monitoring wells revealing the areas geologic, physical and chemical characteristics have been completed. Short \& long term drawdown, injection and extraction tests were conducted to assess hydraulic properties. Pneumatic data derived from soil vapor extraction efforts has also been collected.

\section{Site Layout (Plan View)}

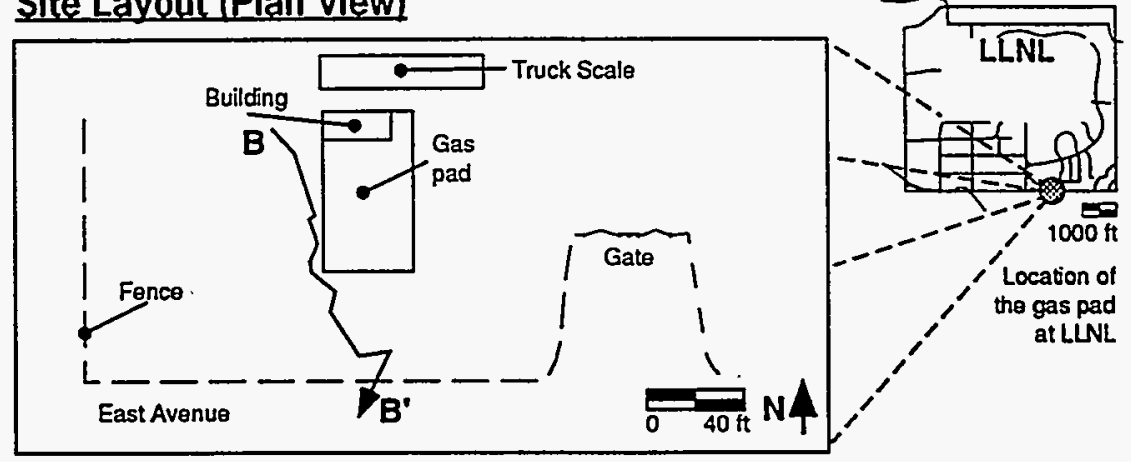

\section{Cross-Sectional View}

4 Hydrogeologic units and 7 hydrostratigraphic layers have been identified along cross-section B-B' shown in the plan view above. A FHC concentration profile along this same cross-section is provided in the "Performance" section on $p .9$.

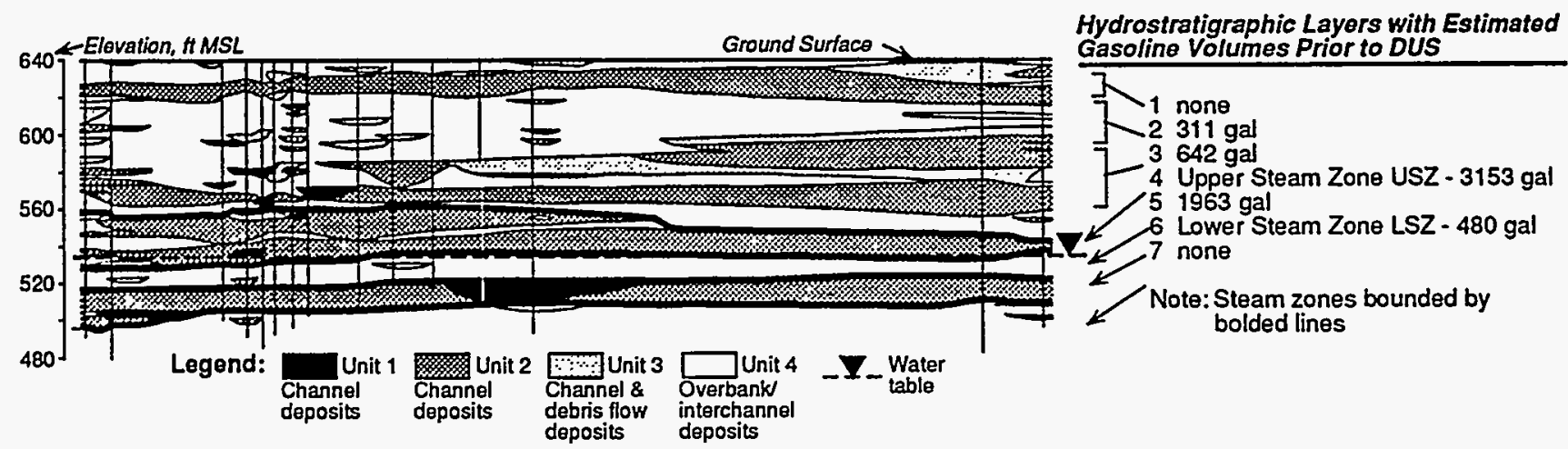

Hydrogeologic Unit Characterization

Hydraulic

Conductivity interpreted

\# Range [gpd/ft2] Permeability

$\begin{array}{lll}15 \text { to } 1070 & \text { Very high to high }\end{array}$ (mean=280)

213 to 1000

316 to 170

$4<5$ to 18
Moderate to low

(mean=116)

\section{Hydrostratigraphic Layer Characterization}

1 5-15 ft thick interval of coarse-grained high-permeability sandy gravels and gravelly sands $230 \mathrm{ft}$ thick, laterally continuous interval of clayey silts to silty clays

3 very heterogeneous zone of elongated lenses of channel sands and gravels interbedded with intervals of silty clays and clayey silts from 50 to $80 \mathrm{ft}$ depth; forms aquitard over USZ 4 partially saturated water-bearing zone composed of a heterogenous mix of high to low permeability sandy to clayey gravels and gravelly to silty sands, 80 to $100 \mathrm{ft}$ depth

5 low-permeability silty clays and clayey silts; forms barrier between the USZ and LSZ

6 high-permeability laterally continuous gravelly sands and sandy gravels; ave $11 \mathrm{ft}$ thick

7 laterally continuous sequence of silty clays to clayey silts at least $15 \mathrm{ft}$ below base of LSZ

NOTE: The 2 steam zones appear to be hydraulically isolated from adjacent aquifers, are relatively permeable and contain the most elevated FHC concentrations. 


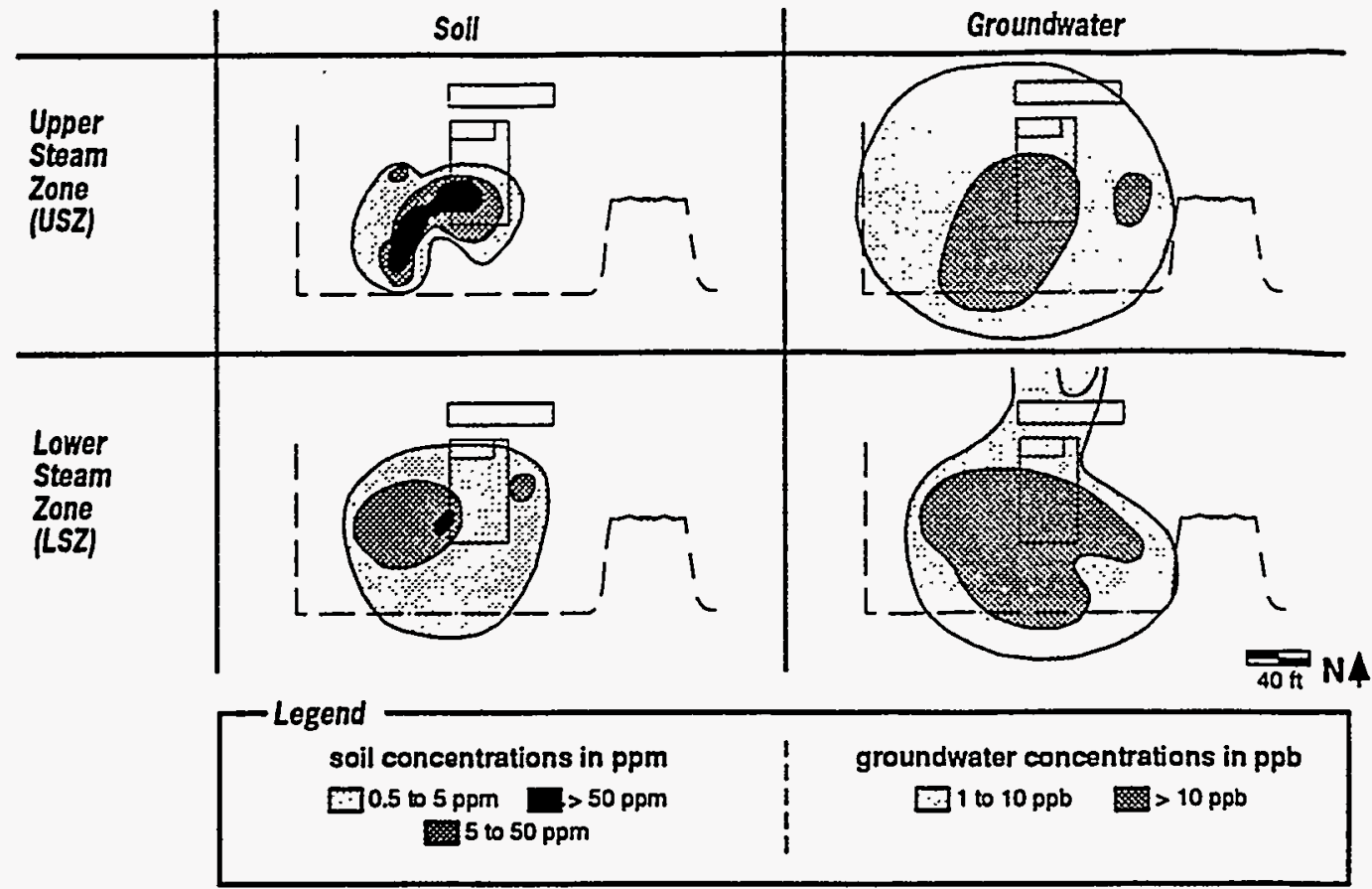

\section{Key Soil/Aquifer Characteristics}

- The site is underlain by several hundred feet of complexly interbedded alluvial and lacustrine sediments. A shallow groundwater system of predominantly heterogeneous alluvial deposits and a deeper groundwater system of fluvial and lacustrine sediments are divided by a confining aquitard.

- Depth to groundwater varies from about $120 \mathrm{ft}$ in the southeast corner of LLNL to about $25 \mathrm{ft}$ in the northwest corner. Depth to groundwater in the GSA is approximately 100 to $120 \mathrm{ft}$.

- Regional groundwater flow is generally westward, locally stratified and primarily horizontal.

- Pumping tests and the distribution of contaminants at LLNL indicate a high degree of horizontal subsurface communication. Minimal observed communication in the vertical direction and the layered alluvium prevent significant downward migration of contaminants.

- Physical parameters measured on sediment cores from 60 to $150 \mathrm{ft}$ depths within the center of the GSA were:

$\begin{array}{lllll}\text { Bulk Density } & 1.44-1.87 & \text { Particle Density } & 2.50-2.94 & \text { Organic Carbon [\%] } \\ \text { pH } & 7.01-7.91 & \text { Sorption constant, Kd } 0.03-0.58 & \text { Cation Exchange Capacity [meq/100g] } & <0.01-0.46 \\ \text { Porosity } & 0.29-0.45 & & \end{array}$

- In addition to GSA hydrogeologic unit data presented on p.2, aquifer parameters for other areas at LLNL have been estimated as:

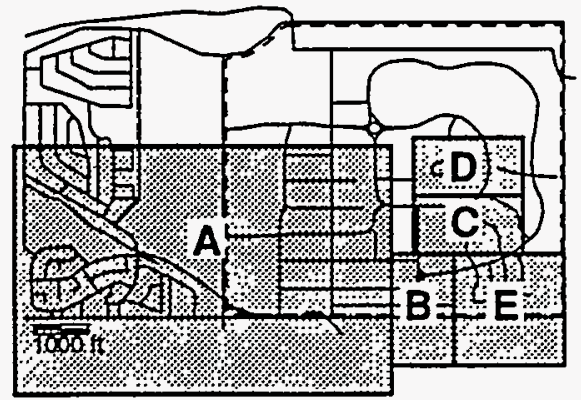

\begin{tabular}{ccccc} 
Area & $\begin{array}{c}\text { Number } \\
\text { of data } \\
\text { points }\end{array}$ & $\begin{array}{c}\text { Hydraulic } \\
\text { Conductivity } \\
\text { [it/d] }\end{array}$ & $\begin{array}{c}\text { Hydraulic } \\
\text { Gradient }\end{array}$ & $\begin{array}{c}\text { Velocity } \\
\text { [ft/y] }\end{array}$ \\
\hline A & 64 & 5.6 & 0.002 & 14 \\
B & 24 & 3.2 & 0.001 & 4 \\
C & 15 & 3.1 & 0.005 & 19 \\
D & 12 & 4.4 & 0.005 & 27 \\
E & 48 & 2.4 & 0.012 & 35
\end{tabular}

- Velocities are calculated based upon a porosity of 0.30 and are applicable only to the area specified. When considering conductivity and velocity over larger areas at LLNL. considerably higher values are appropriate. 


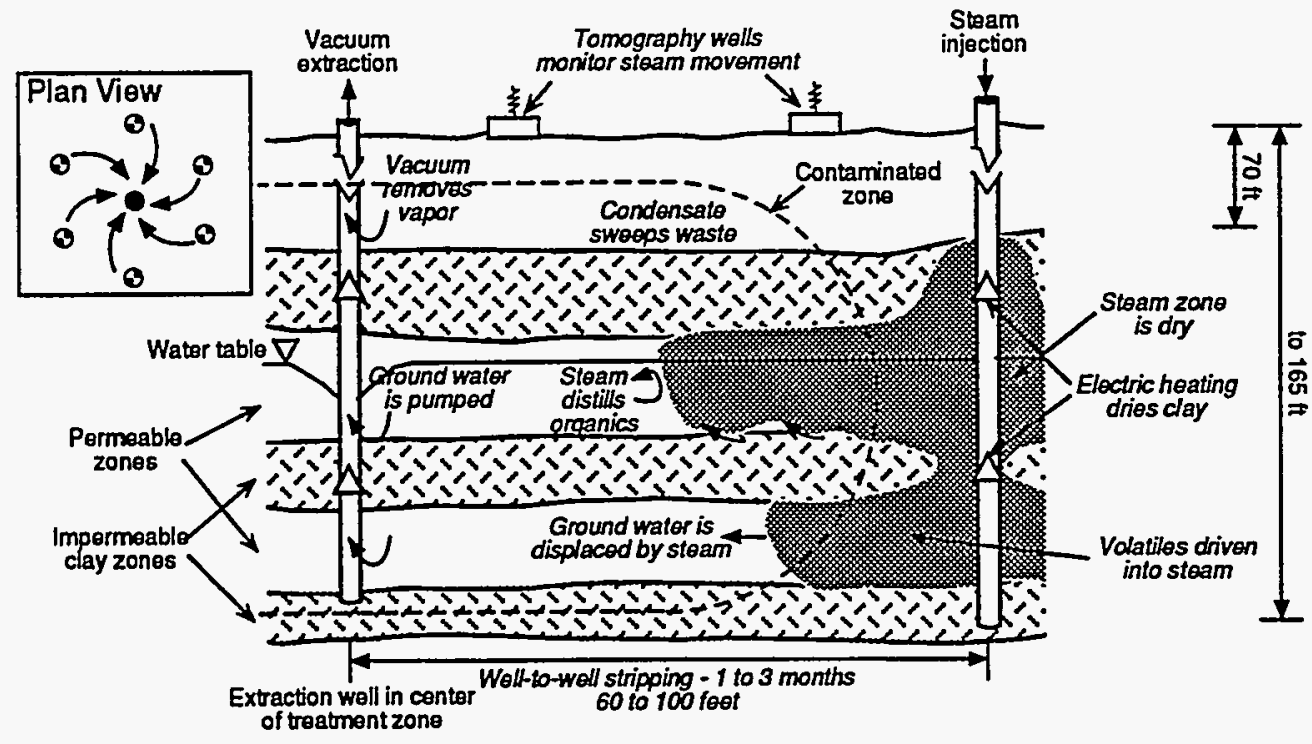

\section{System Configuration}

口

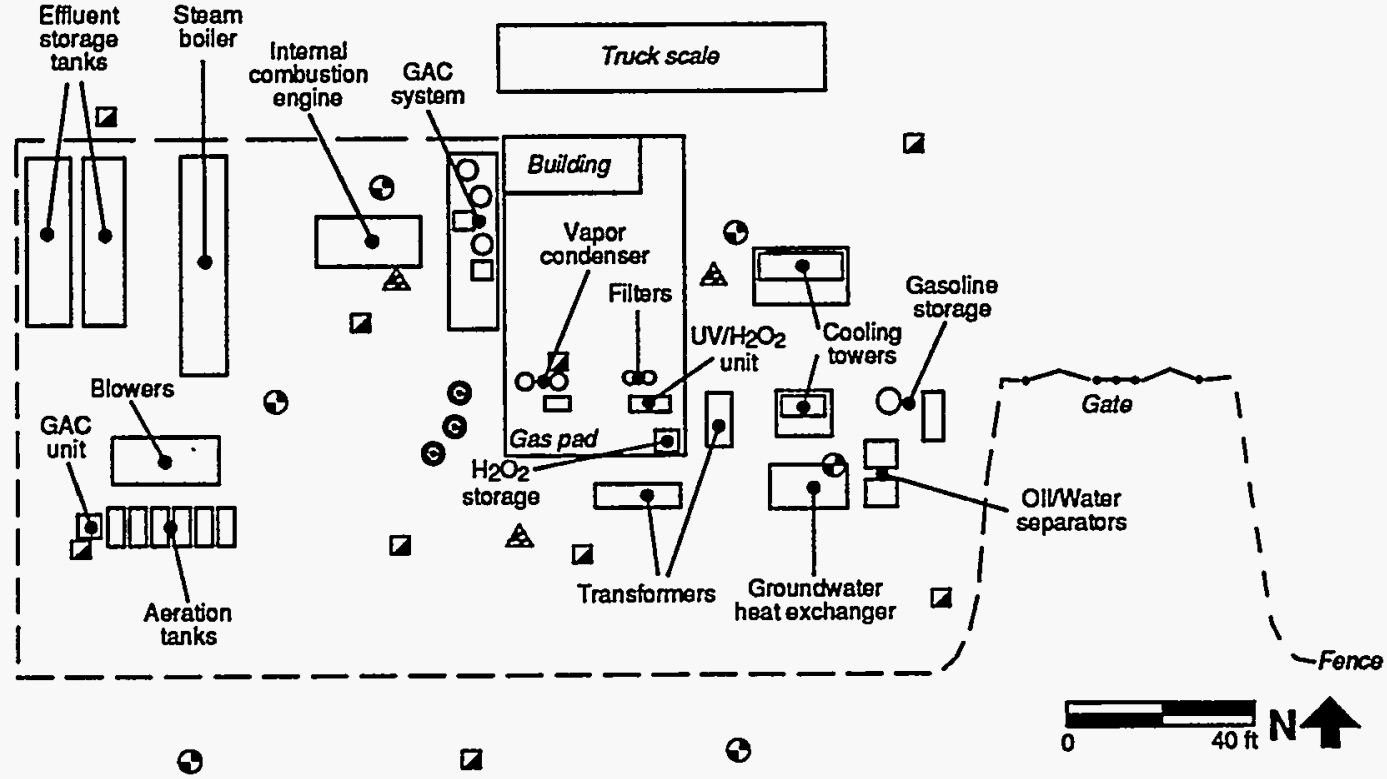

NOTE: 21 Titmeters (not shown) were also utilized. Additional subsurface borings \& groundwater monitoring wells aro present from initial \& ongoing characterization activitios.

- Legend
(a) Extraction
Injection
Electrical 

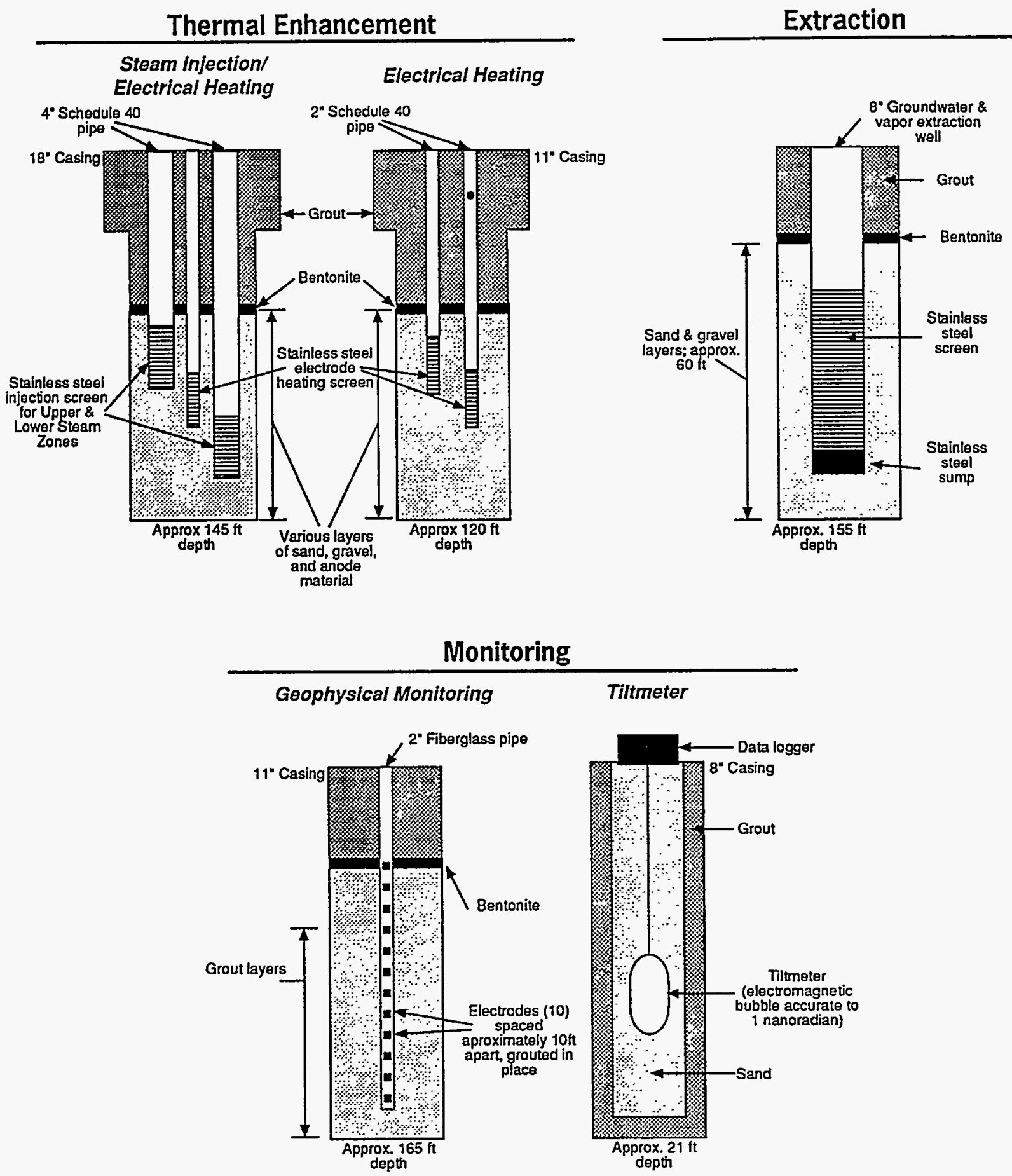

Tiltmeter

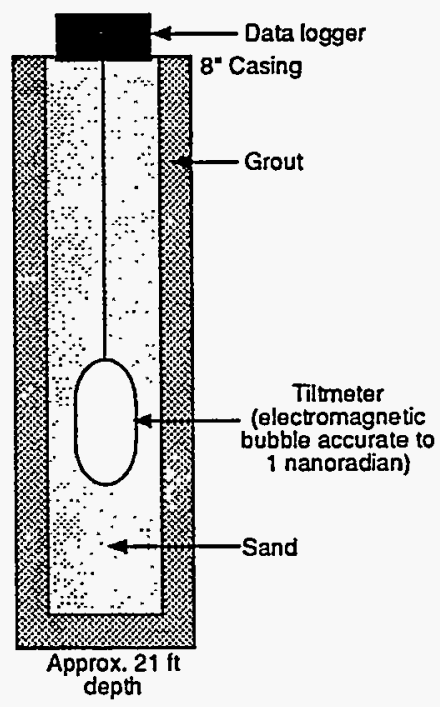

Thermocouples (not shown) are present in the monitoring, steam injection and electric heating wolls All drawings not to scale 


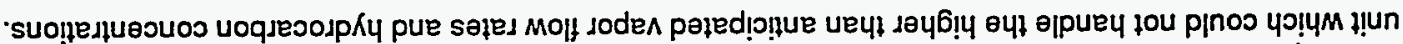

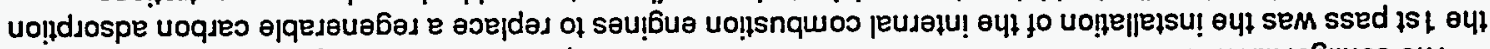

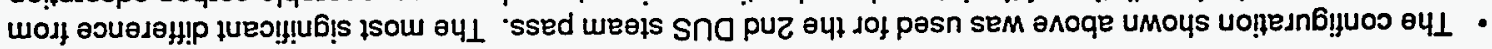

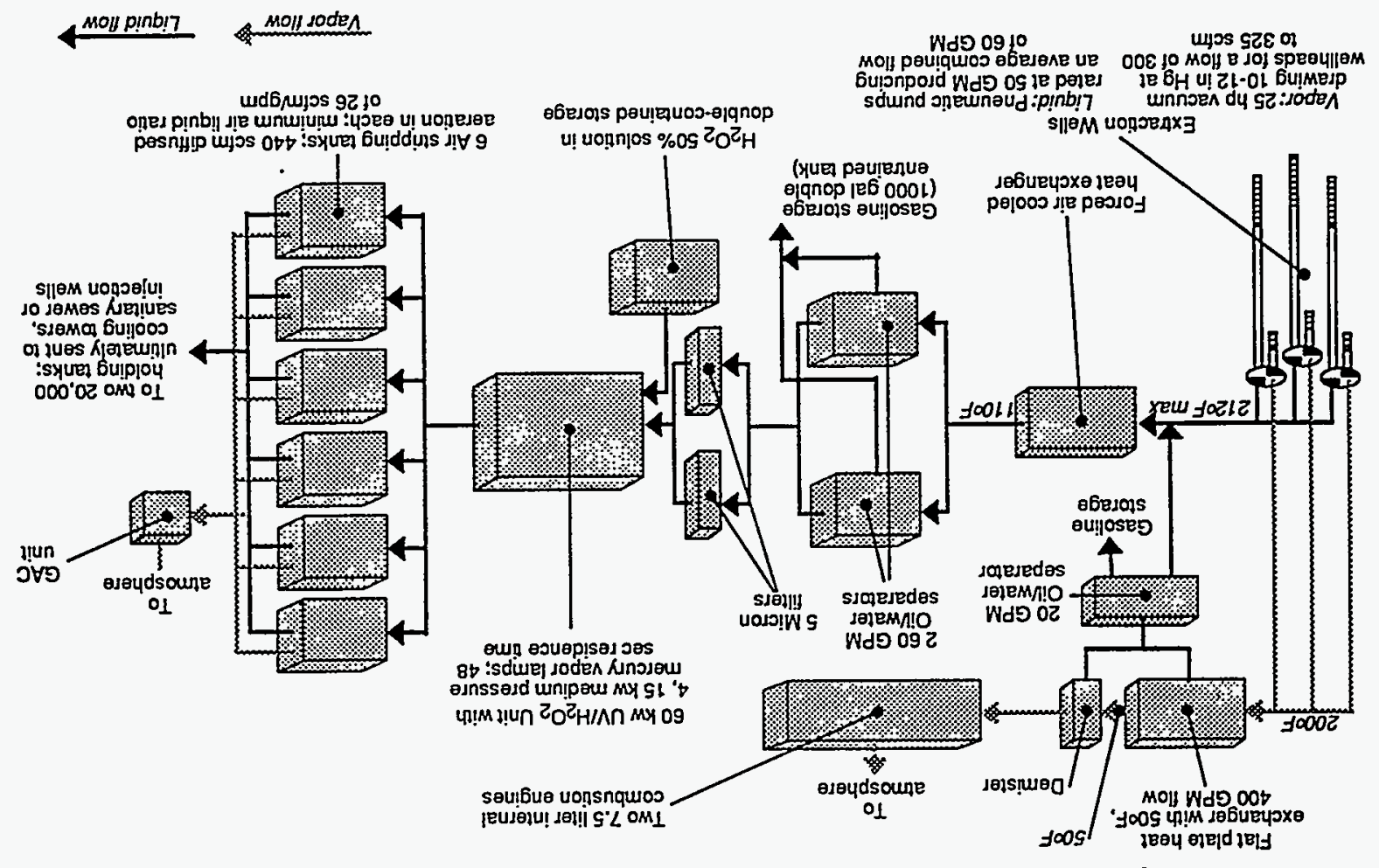

quәud!nb

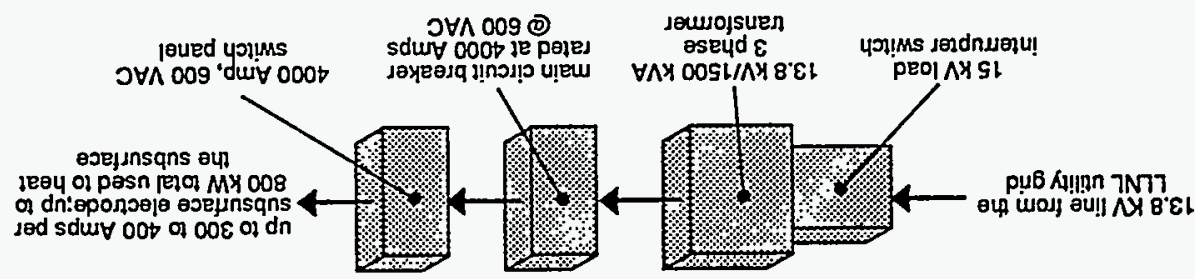

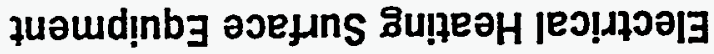

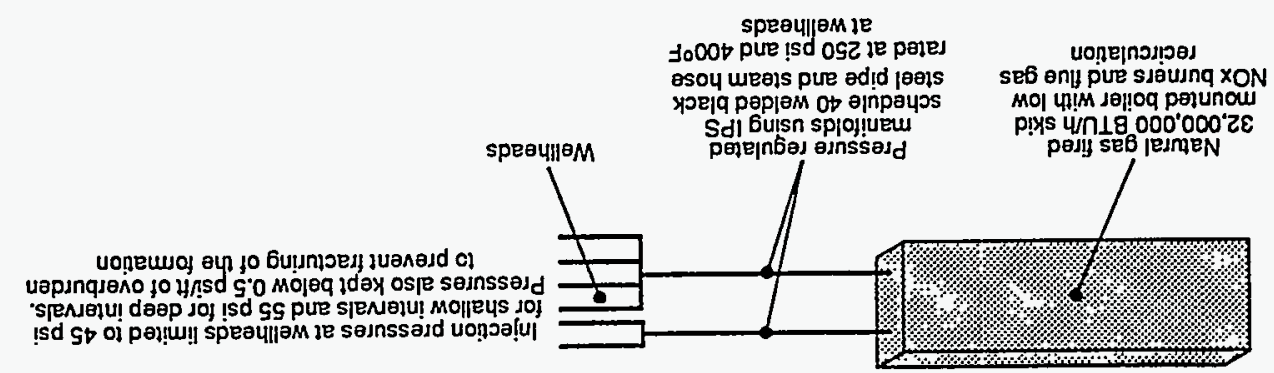

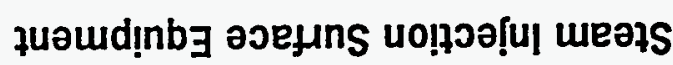




\section{\%ERFORMANCE}

ectives

Performance Objectives

- Satisfying research objectives of each DUS technology demonstration phase

- Avoiding uncontrolled mobilization of contamination

- Removing as much gasoline as possible from the treatment zone [achievement of site cleanup goals (including an MCL of $0.5 \mathrm{ppb}$ for benzene) were not specified objectives]

\section{Demonstration Overview}

DUS activities at LLNL occurred in a series of demonstration efforts:

\section{PHASE}

Clean Site Demonstration

DUS Demonstration Electrical Heating Phase

DUS Demonstration 1st Pass Steaming Phaso

DUS Demonstration 2nd Pass Stoaming Phase

\section{OBJECTIVES/APPROACH}

- To field test the DUS process on an uncontaminated site with well characterized geology

- To heat less permeable contaminated zones

- Continuously steam treatment zone over a 5 week period to remove gasoline

- Intermittently steam and vacuum extract treatment zone over 6 weeks to remove gasoline

- Operate continuously to remove residual contamination

- Test process modifications such as altering injection/extraction locations \& air sparging

- Reheat electrically

- Allow for simultaneous electrical heating \& process monitoring with installation of fiber-optic transmission system

\section{KEY RESULTS}

- Determination of steam injections, electric heating \& monitoring well design improvements

- Identification of improved operating strategy of electric heating prior to steaming

- Soil layers raised from $70^{\circ} \mathrm{F}$ to $160^{\circ} \mathrm{F}$

- Over $1700 \mathrm{gal}$ of gasoline removed

- Over 4900 gal of gasoline removed - Most soils within treatment zone exceed $212^{\circ} \mathrm{F}$; residual contamination (estimated at 750 gal) and an unsteamed area ("cold spot", $170^{\circ} \mathrm{F}$, remained)

- Remainder of free product removed - Over 1000 gal of gasoline removed - Improved understanding of electrical heating process - less effective with groundwater pumping and recharge - Sparging tests demonstrated value of modeling \& use of tracer gases

\section{- Treatment Plan}

A generalized approach to implementing DUS includes

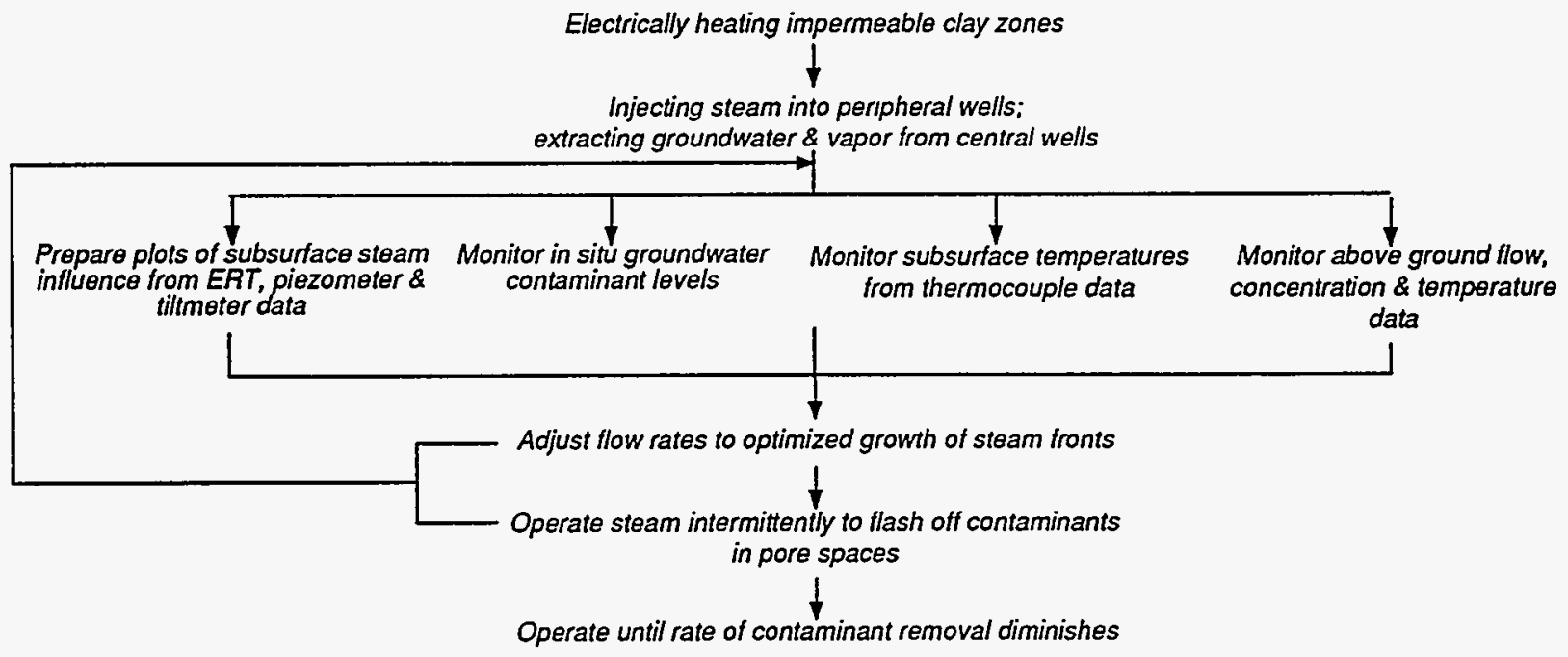




\section{Operational Performance}

- A significant percentage of the field activities occurred in a shakedown mode where various processes were debugged and optimized. In addition, distinct demonstration phases used different equipment configurations. Therefore, long-term routine operational performance data is not available.

- Operational difficulties encountered included biofouling especially from microorganisms destroyed by steaming, scaling and deposits on sensors, clogging from fines brought to the surface and difficulties in maintaining the cycling, pressure varying, high temperature process.

\section{In Situ Heating Performance}

- At total of 100,000 yd3 was heated at least to $2000 \mathrm{~F}$ (boiling point at applied vacuum).

- The growth of the hot zone was monitored by electrical resistance tomagraphy (ERT) and a network of temperature probes and tiltmeters.

- A variety of data was used to prepare multiple representations of heating effects:

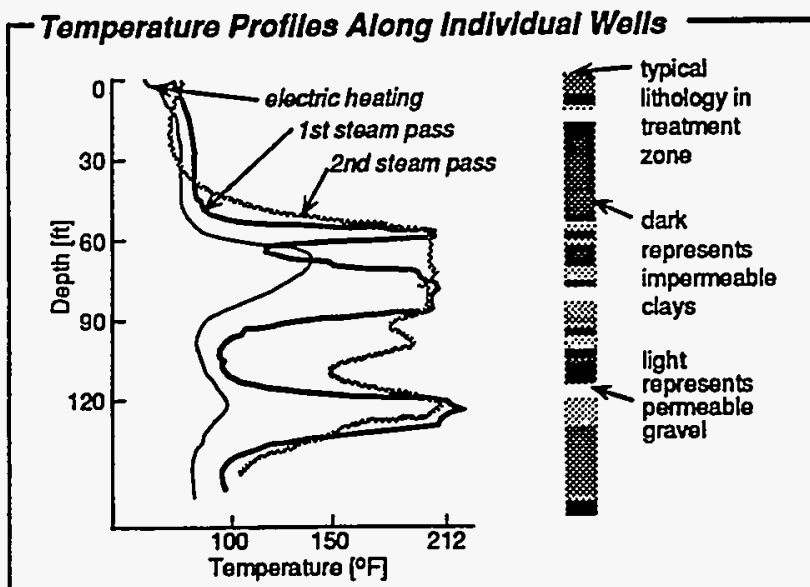

- More permeable layers heat first.

- Heating ultimately effective throughout treatment zone.

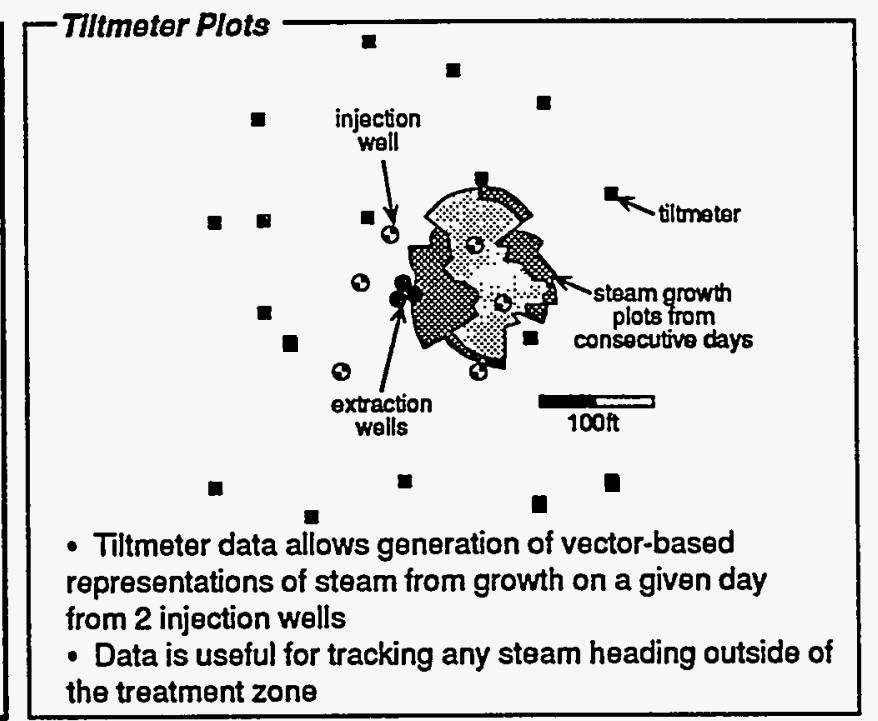

\section{Electrical Resistance Tomagraphy Imaging}

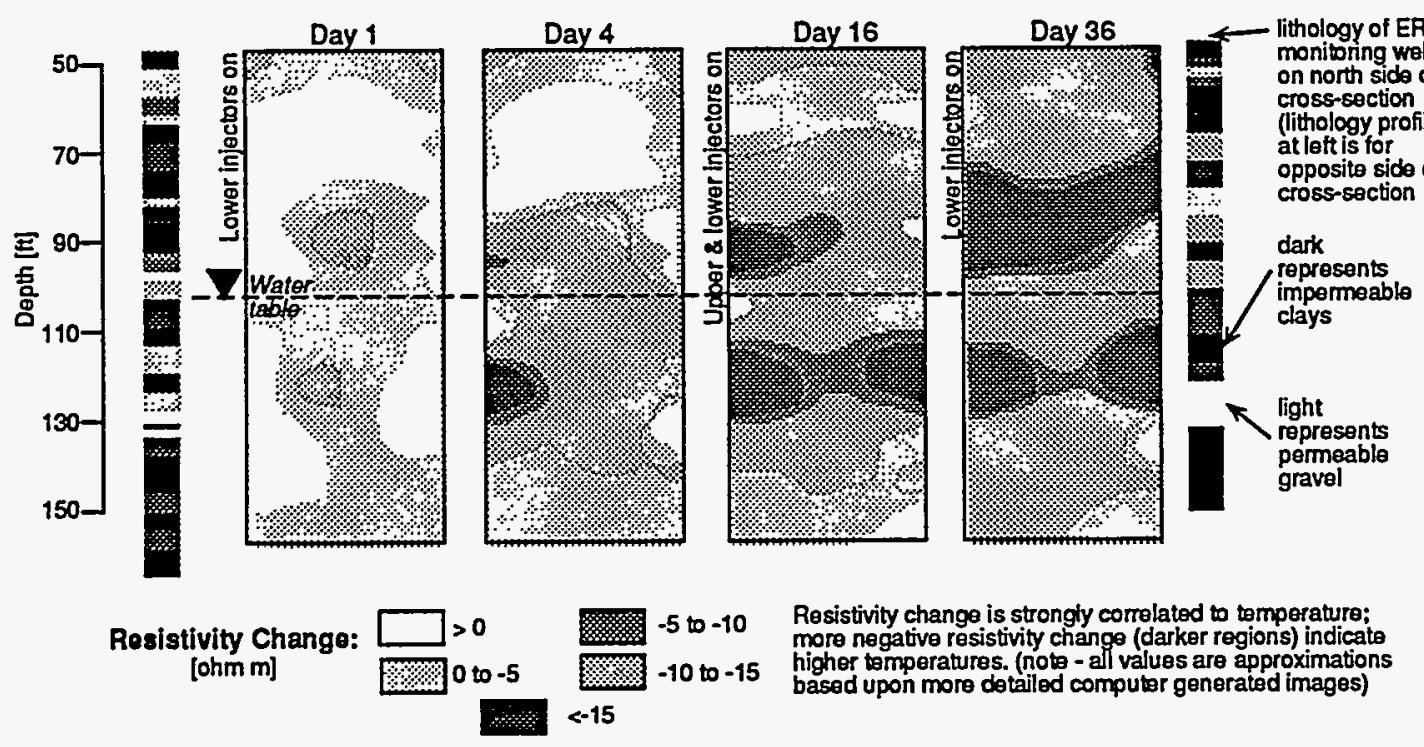

- ERT images provide a continuous representation of steam passage between 2 electrode-equipped boreholes.

- The process allows identification of "cold spots" and provides data on efforts to provide uniform heating. 
In Situ Heating Performance (Continued)

Temperature Proflles Along Individual Well's

- Impermeable layers maintained temperature increases

- Permeable layers were cooled by groundwater pumping especially at peripheral wells due to infiltration of groundwater from outside the treatment zone

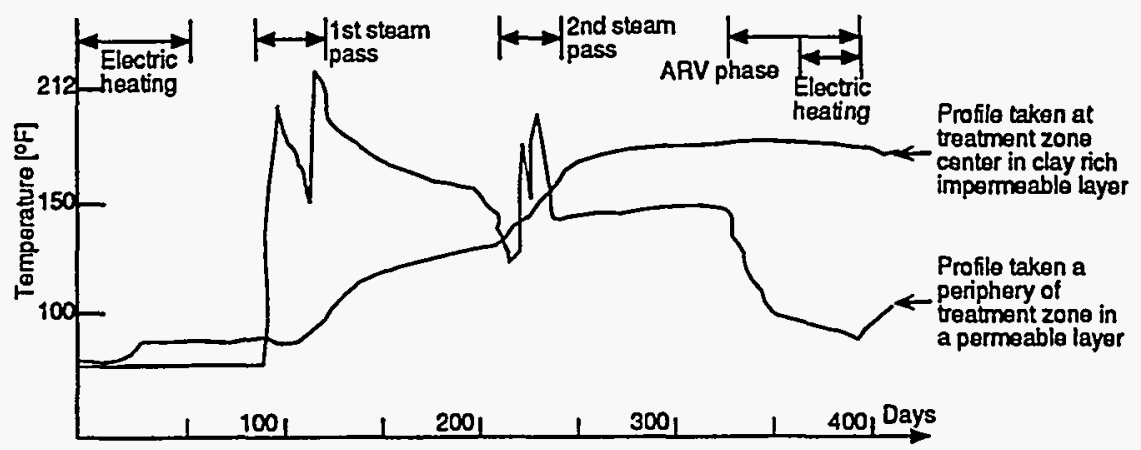

\section{Hydrodynamic Performance}

- The GSA was an ideal spot for demonstration of DUS due to its low groundwater velocities. This kept contamination confined to a relatively small area. The plots at right illustrate that BTEX concentrations at locations at the periphery of the treatment zone declined during the demonstration.
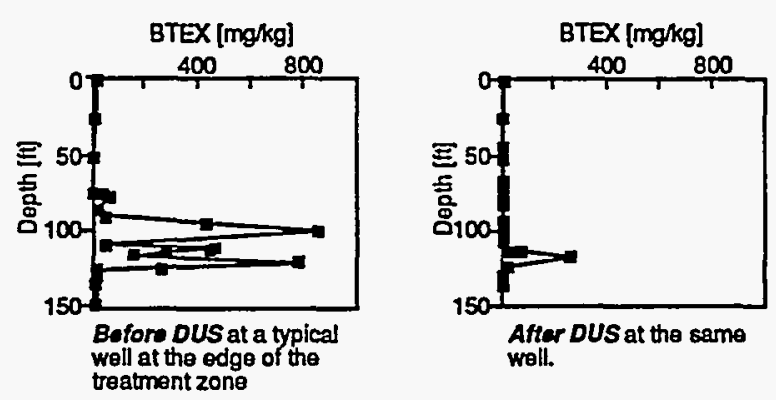

\section{Effects on Site Physical/Chemical/Biological Characteristics}

- No unanticipated bulk changes in physical or chemical soil and groundwater parameters were observed.

- Biological characterizations before and after DUS revealed that viable (although different) microbial populations capable of degrading gasoline were present; the treatment zone was not sterilized.

\section{Treatment Performance}

\section{Effects on Plume}

Estimated Total Fuel Hydrocarbon concentrations before and after the second steam pass of DUS are shown below:
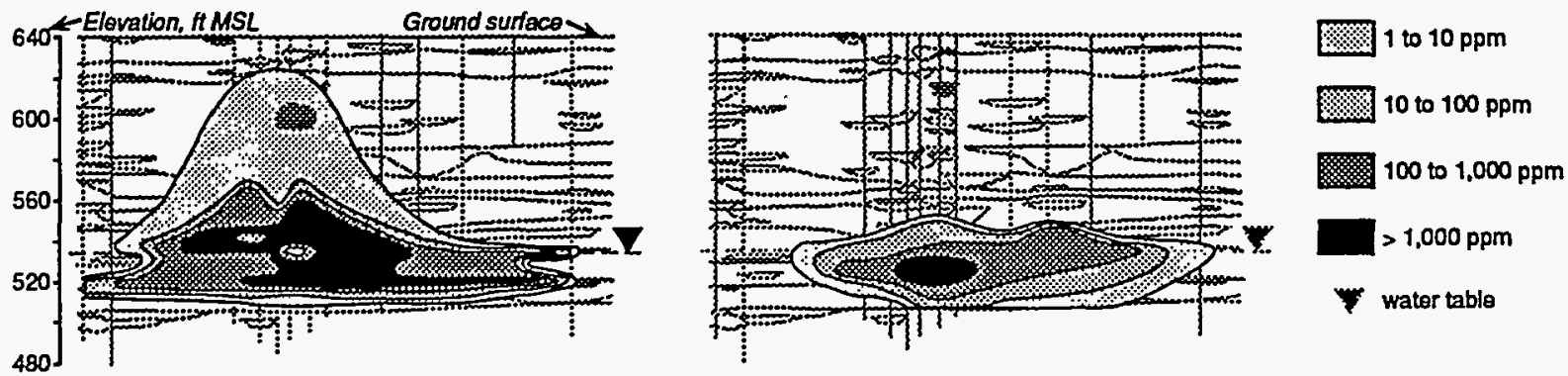

- No spreading observed; contamination drawn to center of treatment zone.

- Continued operation removed an additional 1000 gallons.

- The ability of DUS to remove contaminants sorbed to soils was illustrated by a marked rise in benzene and total gasoline concentrations in groundwater during DUS. At one groundwater monitoring well in the treatment zone, concentrations of $C 6$ to $C 12$ hydrocarbons were below 30 ppm since 1987, but during DUS these concentrations rose to nearly $150 \mathrm{ppm}$ before dropping to levels below those found before DUS. 


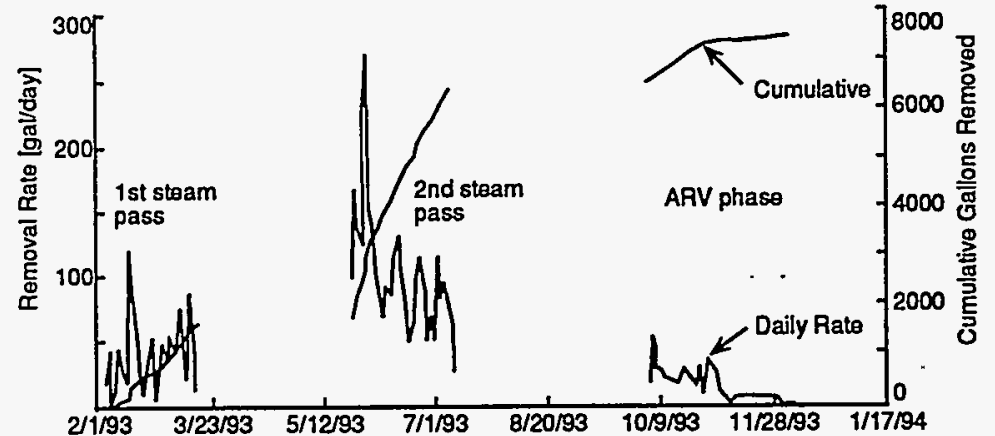

- During the DUS 1st steam pass, $74 \%$ of the 1683 gallons removed were collected by the vapor stream GAC unit. An additional 17\% condensed in the vapor stream and the remaining $9 \%$ was dissolved in groundwater.

- During the 2 nd steam pass, $77 \%$ was burned by the internal combustion engines, $21 \%$ was condensed and $1 \%$ was dissolved.

\section{Above Ground Treatment Plant Performance}

$U \mathrm{~V} / \mathrm{H}_{2} \mathrm{O}_{2}$ - Destruction efficiencies during the last half of the 1 st steam pass were less than $40 \%$ but

Unit adjustments maintained an efficiency over $90 \%$ during the last half of the second steam pass.

- Free gasoline product was found in the unit after the 1 st steam pass.

GACIICE

- The GAC unit was undersized for the vapor flows encountered."

Units

- The ICE unit could also have been larger but nevertheless performed successfully. Dilution air was necessary since hydrocarbon concentrations were above the explosive limit.

- Majority of contaminant was removed in the vapor phase. 
Project costs were obtained from LLNL from a variety of sources. The cost sections below detail costs based upon overall funding received from the Department of Energy, program management planning documents, capital costs for individual equipment components, and actual operating costs incurred during the 2 nd steam pass (which is most representative of operating costs for future applications). In addition, LLNL has prepared an estimate of potential cost savings if DUS were applied at the same site in the future with the benefit of lessons learned and without research-oriented activities. A summary of that estimate is also presented.

DUS costs were compared to estimated costs of applying alternative technologies at the GSA:

$\begin{array}{lrl}\text { DUS } & \$ 10-11 \mathrm{M} & \text { (clean up in } 9 \text { months) } \\ \text { DUS with lessons learned (see next page) } & 6 \mathrm{M} & \text { (clean up in } 6 \text { months) } \\ \text { Soil excavation \& removal } & 30 \mathrm{M} & \text { (clean up in 1 year) }\end{array}$

Pump \& treat with soil vapor extraction 25M (clean up over 30 years)

\section{Overall Program Costs}

Construction through 1 st Steam Pass
2nd Steam Pass
ARV Phase

Construction through 1 st Steam Pass

ARV Phase
$\$ 7.240 \mathrm{M}$

$2.200 \mathrm{M}$

$1.000 \mathrm{M}$

Note: Costs inciuch all research \& developmentcosts associatod

\section{Program Costs Through 1st Steam Pass \& Selected Capital Cost Components}

Program Costs: The following program elements were taken from planning documents. Actual costs were approximately $5 \%$ lower:

\section{Project Management}

Management

Post analysis \& report writing

Review \& write safety plans

Permitting

Equipment design

$$
\begin{array}{r}
\$ 225,000 \\
335,000 \\
70,000 \\
65,000 \\
200,000 \\
\$ 896,000
\end{array}
$$

\section{Process Monitoring}

Design

ERT \& thermal

Tiltmeter

Hydraulic testing
Characterization \& Compliance Monitoring

Drilling phase sampling $\$ 315,000$

Pre-electrical heating sampling $\quad 35,000$

Pre-steam sampling 20,000

Post-steam sampling (4 new wells) $\quad 50,000$

Compliance monitoring $\quad 10,000$

During experiment sampling $\quad 25,000$

$\$ 50,000$

270,000

70,000

$\underline{55,000}$

$\$ 445,000$

Selected Component Costs: The following capital cost items include overlaps with the program cost elements shown above:

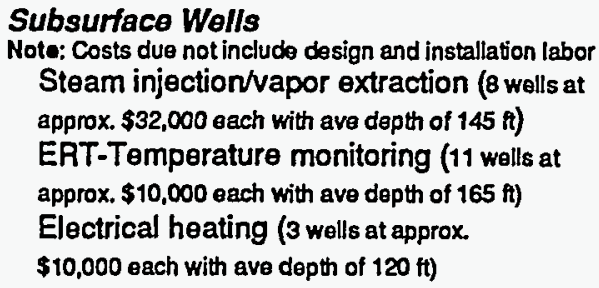

Electrical Heating Surface Equipment

Note: Costs due not include design and engineering Installation labor

Transformer

Circuit breaker/switch panel

Cable

Miscellaneous materials

Other direct costs
Steam Generation Surface Equipment

Note: Boiler leased for $\$ 17,300 /$ month; design costs not included

Installation labor $\quad \$ 174,000$

Boiler utility set-up $\quad 100,000$

Miscellaneous materials $\quad 42,000$

$\$ 110,000 \quad$ Other direct costs $\quad 79,000$

$\$ 30,000$

$\$ 129,000$

50,000

40,000

18,000

67,000

63.000

$\$ 367,000$
Extracted Groundwater \& Vapor Surface Treatment Systems - Treatment Facility F Note: Costs do not include design and engineering; facility originally designed for 30 year pump \& treat mission

Piping \& power

$\$ 1,512,000$

Process equipment

400,000

Vapor modifications for DUS $\quad 160,000$

Discharge pipeline $\quad 87,000$

Activation

80,000

Other direct costs 


\author{
Utillty Consumption \\ Boiler natural gas (3.8E10 cu.ft @ \$0.39/100,000 cu.tt) \\ Boiler water (3.6E6 gal @ \$1.25/100 cu.ft) \\ Boiler electricity $(40,000 \mathrm{kWh} @ \$ 0.06 / \mathrm{kWh})$
}

Electricity for electrical heating $(200,000 \mathrm{kWh} @ \$ 0.06 / \mathrm{kWh})$

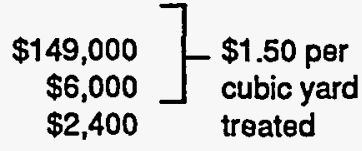

$\$ 12,000$

Labor \& Materlal Costs for 2nd Steam Pass (all values in thousands of dollars) Note: Costs represent 6 weeks of 24 hr operations and continuously monitored experimental conditions

\begin{tabular}{|c|c|c|c|c|c|}
\hline & $\begin{array}{c}\text { Scientists \& } \\
\text { Engineers }\end{array}$ & Technicians & $\begin{array}{l}\text { External } \\
\text { Analysis }\end{array}$ & Materials & TOTALS \\
\hline Phase 1: Planning & 44 & $\cdot$ & - & - & 44 \\
\hline Phase 2: Maintenance \& Modification & 2 & 31 & - & 27 & 60 \\
\hline \multirow{2}{*}{\multicolumn{6}{|c|}{$\begin{array}{l}\text { Phase 3: Operations } \\
\text { Steam Injection Operations }\end{array}$}} \\
\hline & & & & & \\
\hline Periods of steam injection & 27 & 51 & - & 167 & 245 \\
\hline Periods of no steam injection & 14 & 5 & - & - & 19 \\
\hline ERT Monitoring & 13 & 22 & - & - & 35 \\
\hline Additional UC Berkeley support & - & 50 & - & - & 50 \\
\hline \multicolumn{6}{|l|}{ Effluent Treatment Operations } \\
\hline Effluent treatment & 35 & 203 & - & 91 & 329 \\
\hline Sampling \& analysis & 50 & 17 & 18 & - & 85 \\
\hline \multicolumn{6}{|l|}{ Phase 4: Post Steaming Characterization } \\
\hline Sampling & 41 & 36 & - & - & 77 \\
\hline Soil Analysis & - & - & 83 & - & 83 \\
\hline Drill Rig & - & 26 & - & 9 & 35 \\
\hline \multirow{3}{*}{$\begin{array}{l}\text { Phase 5: Reporting \& Technology Transfer } \\
\text { Phase 6: Dismantling (conservative estimate) } \\
\text { Contingencies }\end{array}$} & 400 & $\cdot$ & - & - & 400 \\
\hline & & & & & $\begin{array}{l}181 \\
228\end{array}$ \\
\hline & & & & tal & 51,870 \\
\hline
\end{tabular}

\section{Estimated Cost Savings for Reapplication/Cost Sensitivities}

LLNL has prepared an estimate of potential cost savings if DUS were applied at the same site in the future with the benefit of lessons learned and without research-oriented activities. The estimated savings would be derived from:

- reduction in design effort by over $50 \%(-\$ 206 K)$

- elimination of discharge lines \& transformer modifications $(-855 \mathrm{~K})$

- use of temporary steam generation equipment (-355K)

- reduced site characterization (-210K)

- replacement of UV unit with air stripper (-500K)

- elimination of modification designs for 2 nd pass steam and ARV phases (-604K)

- reduced management efiort $(-100 \mathrm{~K})$

- reduced science \& engineering staff requirements (-166K)

- reduced operations staff requirements $(-505 \mathrm{~K})$

- reduced reporting and safety documentation preparation $(-470 \mathrm{~K})$

Resultant total savings would be approximately $\$ 4,000,000$ 


\section{REGULATORY/NSTITUTIONAL ISSUES}

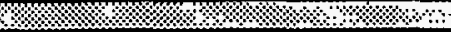

- The timetable for the DUS demonstration was dictated by the air permits issued for the project. The system was shut down while it was still removing $50 \mathrm{gal} /$ day of gasoline and an unheated region remained because the air discharge allowances had been consumed.

- The boiler for steam generation utilized Best Available Control Technology (BACT) consisting of a low NOx burner design and flue gas recirculation to control NOx emmission to $40 \mathrm{ppm}$. The Bay Area Air Quality Management District (BAAQMD) granted a research exemption for the project rather that requiring LLNL to purchase an emission allotment of $2,200 \mathrm{lbs}(1.6 \mathrm{lbs} / \mathrm{h})$ of NOX.

- The BAAQMD issued permits for the following:

\begin{tabular}{lccc} 
DISCHARGE & COMPOUND & SAMPLING & DISCHARGE \\
\hline Air stripper & Total Hydrocarbons & $5 / w k$ & LIMIT \\
GAC & Total Hydrocarbons & $5 / w k$ & $10 \mathrm{ppm}$ \\
IC Engine & Total Hydrocarbons & $5 /$ wk & Destruction $>98.5 \%$ \\
Sitewide benzene & Benzene & Monthly & $1.815 \mathrm{lb} /$ day
\end{tabular}

- National Pollution Discharge Ellimination System (NPDES) water discharge limits issued by the Bay Area Regional Water Quality Control Board (RWQCB) mandated MCLs for effluents. The system was designed to satisfy the limits, however, during upset conditions, effluent was sampled and sent to a sanitary sewer regulated by the Livermore Water Reclamation Plant.

\section{SCHEDULE}

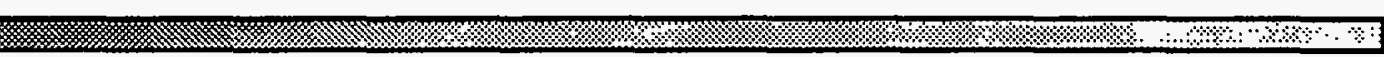

\section{Major Milestones}

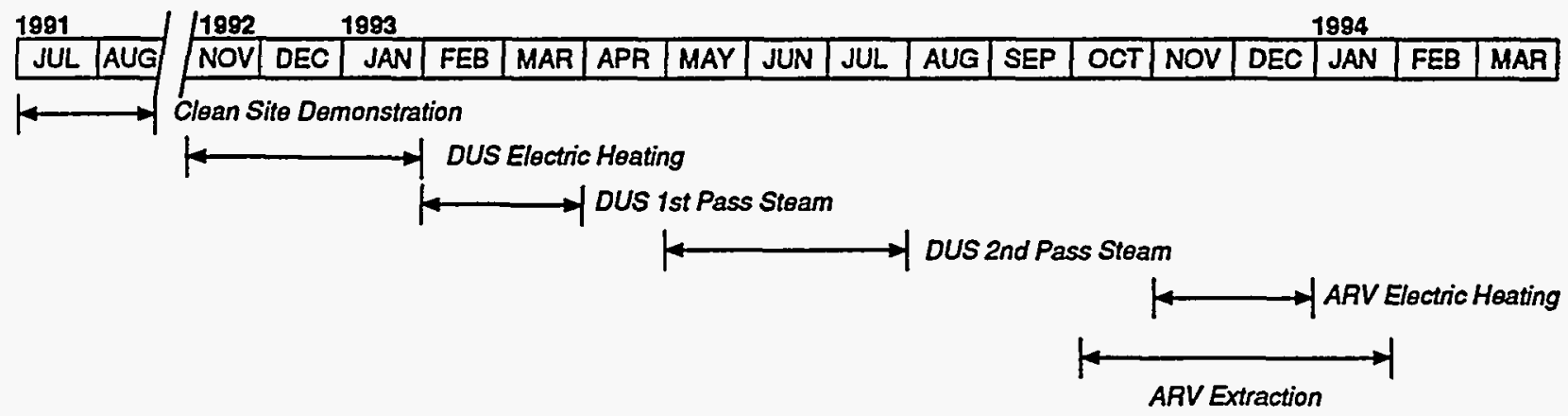


- The DUS demonstration made use of an existing groundwater treatment unit designed to treat gasoline and low levels of chlorinated solvents over a long period of time using oil/water separation, $U \mathrm{~V} / \mathrm{H}_{2} \mathrm{O}_{2}$, and $\mathrm{GAC}$ for the liquid phase and GAC for the vapor phase. This design was not optimal for DUS conditions. The large vapor flows loaded with fuel hydrocarbons required installation of an internal combustion engine to replace the GAC. The high temperature process created conditions unfavorable to UV treatment (increased carbonates and silicates in the extracted liquids would come out of solution when cooled in the UV unit. Packed tower air stripping may be more appropriate for similar applications in the future

- The success of the DUS process is dependent upon boiling the subsurface environment. The process must be designed not only to bring soil and groundwater to steam temperature but to impart a large amount of energy to create a complete steam zone.

- Above ground equipment must be able to handle large peak extraction rates and rapid changes in rate.

- Most of the recovered gasoline is in the vapor phase rather than separated out of the extracted groundwater. Vapor recovery systems must be sized accordingly.

- Above ground treatment units should be configured not to interfere with access to the subsurface treatment zone.

\section{Implementation Considerations}

- Effective removal of contaminants from the subsurface requires alternating steam-injection and vacuum extraction phases. The pressure changes created by this oscillatory approach distills contaminants from pore spaces in both saturated and unsaturated sediments.

- Extraction rates can vary greatly depending upon the amount of steam injected, the total vacuum applied and cycle times.

- Permitting of air discharges both from the above ground treatment units as well as from equipment used to supply steam energy is an issue requiring early attention.

- DUS is a labor intensive process requiring significant field expertise to implement.

- Electrical Resistance Tomography (ERT) proved to be the most effective method for monitoring the DUS process in real time. Alternative geophysical techniques could be used for other applications.

\section{Technology Limitations}

- Data on long-term routine operating experience with DUS is not yet available.

- Future development needs currently identified for DUS include demonstrating the process for removing chlorinated solvents, automating monitoring techniques and further refining system design and operating techniques.

\section{Future Technology Selection Considerations}

- DUS was effective at quickly removing concentrated free product contaminants including materials sorbed to saturated sediments without mobilizing contaminants outside of the treatment zone.

- Steam injection is effective at heating impermeable zones and repeated steam passes can heat adjacent impermeable areas.

- Electrical heating is effective on clay zones, however, power requirements increase when extracting hot fluids from the treatment zone.

- DUS is compatible with long-term efforts to bioremdiate residual contamination following steam injection. At LLNL, viable microbial populations continued to degrade gasoline at the site at temperatures above $158^{\circ} \mathrm{F}$ after application of DUS.

- DUS can compare favorably in terms of speed, effectiveness and cost with alternative technologies for deep subsurface plumes. At LLNL, significant cost savings were realized from DUS as opposed to installation of soil vapor extraction/pump \& treat systems or excavation of contaminated areas. Further reductions in DUS cost are anticipated as experience is gained optimizing subsequent applications.

\section{U.S. Air Force}


This analysis was prepared by:

Stone \& Webster Environmental
Technology \& Services

245 Summer Street

Boston, MA 02210

Contact: Bruno Brodfald (617) 589-2767

Assistance was provided by the

LAWRENCE LUERMORE NATIONAL LABORATORY

ENVIRONMENTAL RESTORATION DIVISION

which supplied key information and reviewed report drafts.

for:

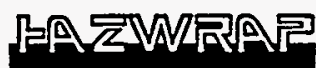

HAZARDOUS WASTE REMEDIAL ACTIONS PROGRAM Environmental Restoration and Wasto Management Programs

Oak Ridge, Tennessee 37831-7606

managed by

MARTIN MARIETTA ENERGY SYSTEMS for the

U.S. Department of Energy under Contract DE-ACO5-84OR-21400

This analysis was funded by:

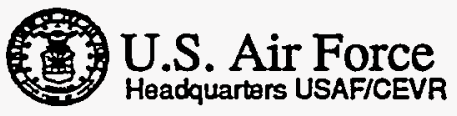

This analysis accurately reflects the performance and costs of the remediation:

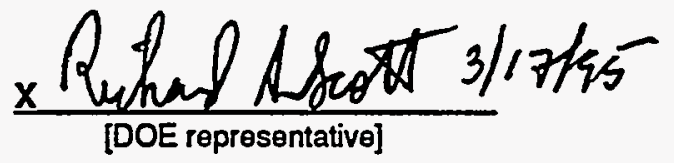


Site Characteristics:

Treatment System:

Portormanco:

Cost:

Regulatory/nstitutional Issues:

Schedule:

Lessons Learned:
Source \#s (from list below) 1 and 13

Source \#s 1, 3, 4, 5, 6, 7. 8. and 9

Source \#s 1,3, 4, 5, 6, 7, 8, 9, 10,11, 12 and 14

Source \#s 1 and 2

Source \#s 1, 4 and 8

Source \# 4, 6. 8.10 and 11

Source \#s 1, 3, 4, 5, 6, 7, 8, 9, 10,11, 12 and 14

\section{Chronological List of Sources and Additional References}

1. Personal communications with Roger Aines, Lawrence Livermore National Laboratory, (510) 423-7184, November-December 1994.

2. Memorandum from Roger Aines, LLNL to Jesse Yow, LLNL, "Summary of Dynamic Underground Stripping Funding, December 19, 1994.

3. Personal communications with Robin Newmark, Lawrence Livermore National Laboratory, (510) 423-3644, November 1994.

4. Design, Construction and Operation of the Dynamic Underground Stipping Facility at Lawrence Livermore National Laboratory, working draft, Lawrence Livermore National Laboratory, Livermore, CA, 1994.

5. Aines, Roger, William Siegel and Everett Sorenson, Gasoline Removal During Dynamic Underground Stripping: Mass Balance Calculations and Issues, working draft, Lawrence Livermore National Laboratory, Livermore, CA. 1994.

6. Aines, Roger, Robin Newmark, John Ziagos, Alan Copeland and Kent Udell, Cleaning Up Underground Contaminants: Summary of the Dynamic Underground Stripping Demonstration, LLNL Gasoline Spill Site, Lawrence Livermore National Laboratory, Livermore, CA., [UCRL-ID-118187], September 1994.

7. Siegel, William H. and Everett Sorenson, Treatment Facility F, internal document, Lawrence Livermore National Laboratory, Livermore, CA. 1994.

8. Yow, Jess L, Roger D. Aines, Robin L. Newmark, Kent S. Udell and John P. Zlagos, Dynamic Underground Stripping: In Situ Steam Sweeping and Electrical Heating to Remediate a Deep Hydrocarbon Spill, draft, Lawrence Livermore National Laboratory, Livermore, CA. 1994.

9. Newmark, Robin L. and the DUS Project Gasoline Spill Site Monitoring Team, Using Geophysical Techniques to Control In Situ Thermal Remediation, draft, Lawrence Livermore National Laboratory, Livermore, CA., 1994.

10. Sweeney, Jerrry J. and Alan B. Copeland [Eds.], Treatment Facility F, Accelerated Removal and Validation Projectt draft, Lawrence Livermore National Laboratory, Livermore, CA., April 1994.

11. Demonstration of Dynamic Underground Stripping at the LLNL Gasoline Spill Site: Summary of Results 3/94, draft, Lawrence Livermore National Laboratory, Livermore, CA., March 1994.

12. Jovanovich, Marina C., Roger E. Martinelli, Michael J. Dibley and Kenneth L. Carroll, Process Monitoring of Organics, draft, Lawrence Livermore National Laboratory, Livermore, CA., January 1994.

13. Bishop, D.J. [ed.], Dynamic Underground Stipping Charactenization Report, draft, Lawrence Livermore National Laboratory, Livermore, CA, January 1994.

14. Brown, Mike, Roger Liddle, Alan Copeland, John Zlagos, "Headquarters Dynamic Underground Stripping Briefing", presentation materials, October 1993. 


\section{DISTRIBUTION}

DOE

S. B. Balone, DOE-HQ EM-40

C. W. Frank, DOE-HQ EM-50

J. C. Lehr, DOE-HQ EM-40

J. O. Moore, DOE-ORO

J. Owendoff, DOE-HQ EM-40

W. C. Schutte, DOE-HQ EM-50

L. E. Velazquez, DOE-ORO

J. S. Walker, DOE-HQ EM-50

J. A. Wright, DOE-SRO

P. R. Zielinski, DOE-HQ EM-40

DOE M\&Os

J. L. Steele, Westinghouse Savannah River Co.

S. L. Stein, Pacific Northwest Laboratory

LOCKHEED MARTIN ENERGY SYSTEMS

S. J. Colburn

H. B. Davidson

G. F. Delong

G. S. Dintsch

G. L. Dippo

R. B. Fitts

C. S. Fore

P. S. Gillis

T. L. Ham

J. W. Johnston

J. J. Kulesz

M. D. Nickelson

A. L. Porell

P. M. Pritz

A. S. Quist - 3 copies ( 2 copies to DOE OSTI)

G. D. Robbins

R. L Snipes

L. A. Stevens

R. L. Walker

M. C. Wheeler 